\title{
Surplus Plutonium Disposition (SPD) Environmental Data Summary
}

by

K. Sullivan (Contact)

Westinghouse Savannah River Company

Savannah River Site

Aiken, South Carolina 29808

P. D. Fledderman

This paper was prepared in connection with work done under the above contract number with the U. S. Department of Energy. By acceptance of this paper, the publisher and/or recipient acknowledges the U.S. Government's right to retain a nonexclusive, royalty-free license in and to any copyright covering this paper, along with the right to reproduce and to authorize others to reproduce all or part of the copyrighted paper. 
This document was prepared in conjunction with work accomplished under Contract No.

DE-AC09-96SR18500 with the U.S. Department of Energy.

\section{DISCLAIMER}

This report was prepared as an account of work sponsored by an agency of the United States Government. Neither the United States Government nor any agency thereof, nor any of their employees, makes any warranty, express or implied, or assumes any legal liability or responsibility for the accuracy, completeness, or usefulness of any information, apparatus, product or process disclosed, or represents that its use would not infringe privately owned rights. Reference herein to any specific commercial product, process or service by trade name, trademark, manufacturer, or otherwise does not necessarily constitute or imply its endorsement, recommendation, or favoring by the United States Government or any agency thereof. The views and opinions of authors expressed herein do not necessarily state or reflect those of the United States Government or any agency thereof.

This report has been reproduced directly from the best available copy.

Available for sale to the public, in paper, from: U.S. Department of Commerce, National Technical Information Service, 5285 Port Royal Road, Springfield, VA 22161, phone: (800)

553-6847, fax: (703) 605-6900, email: orders@ntis.fedworld.gov online ordering: http://www.ntis.gov/ordering.htm

Available electronically at http://www.doe.gov/bridge

Available for a processing fee to U.S. Department of Energy and its contractors, in paper, from: U.S. Department of Energy, Office of Scientific and Tech nical Information, P.O. Box 62, Oak Ridge, TN 37831-0062, phone: (865 ) 576-8401, fax: (865) 576-5728, email: reports@adonis.osti.gov 
ESH-EMS-2000-849

Rev. 0

August 3, 2000

\section{Surplus Plutonium Disposition (SPD) \\ Environmental Data Summary}

P.D. Fledderman

Environmental Monitoring Section

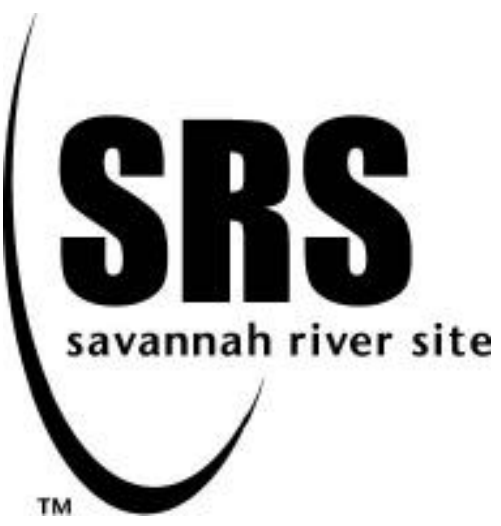




\section{Table of Contents}

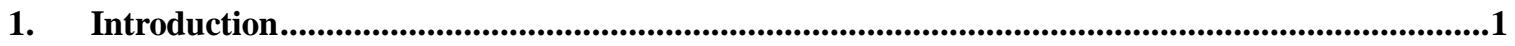

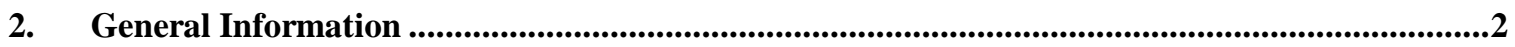

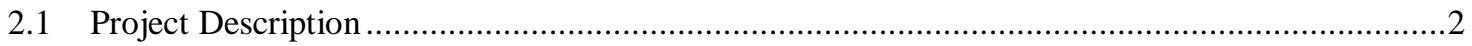

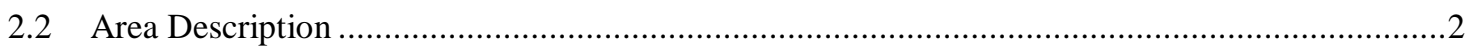

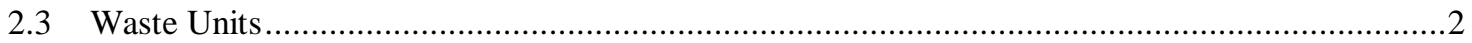

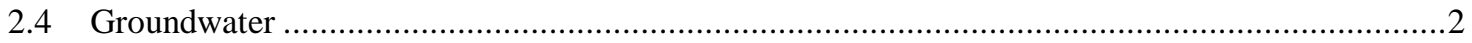

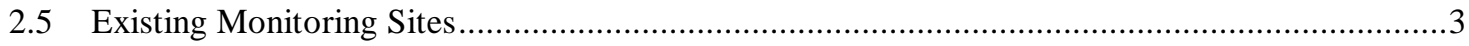

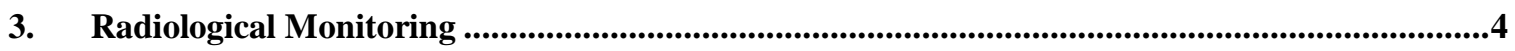

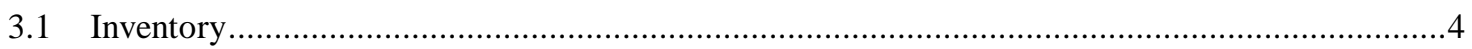

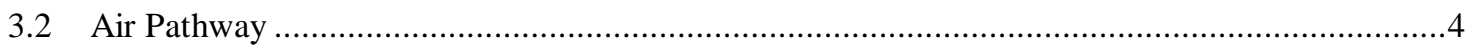

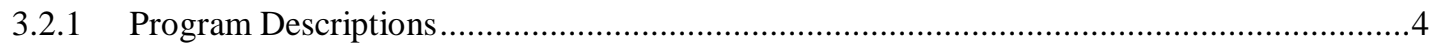

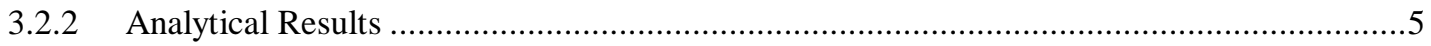

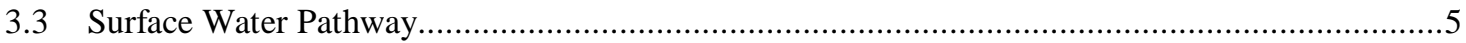

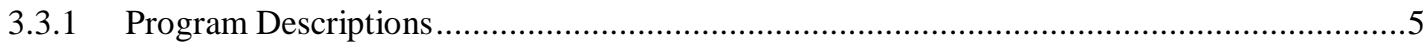

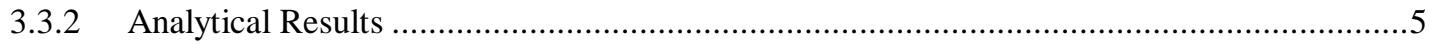

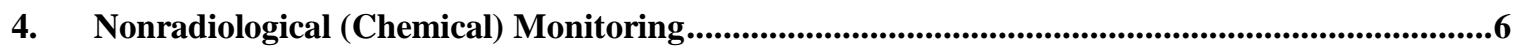

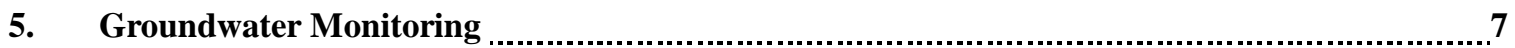

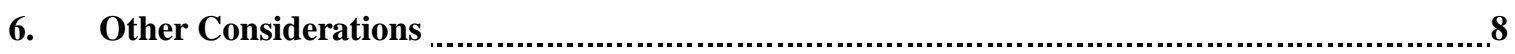

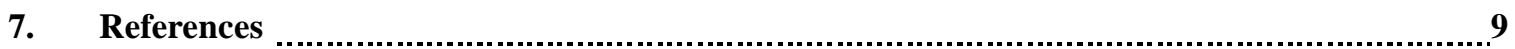




\section{List of Tables}

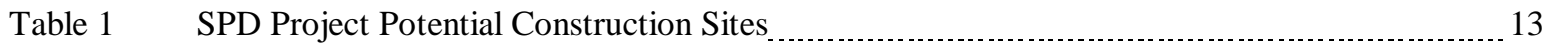

Table 2 Waste Units and ECODs within the SPD Project Area

Table 3 Monitoring Locations within the SPD Project Area 15

Table 4 Monitoring Wells within the SPD Project Area

Table 5 Inventory of Radionuclides Released from F-Area $\ldots$

Table $6 \quad 1973$ F-Area Special Soil Survey

Table 7 Current NPDES Monitoring Requirements $\ldots$ 


\section{List of Figures}

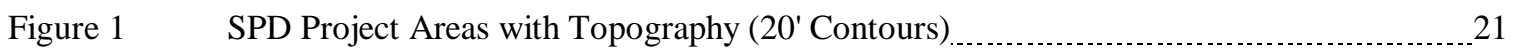

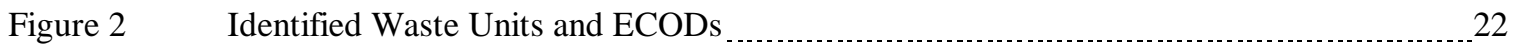

Figure 3 Water Table Elevation and Well Locations 23

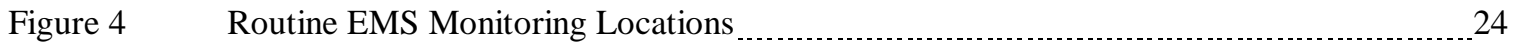

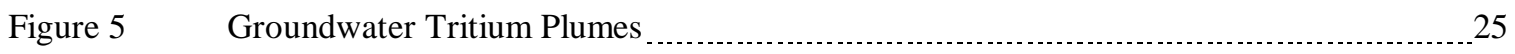

Figure 6 Comparison of Airborne Gross Alpha Concentrations at All Locations _..._._._._..... 26

Figure 7 Comparison of Airborne Gross Beta Concentrations at All Locations _...........................27

Figure $8 \quad$ Comparison of Tritium-in-Air Concentrations at All Locations _.............................. 28

Figure 9 Gross Alpha and Gross Beta Concentration 29

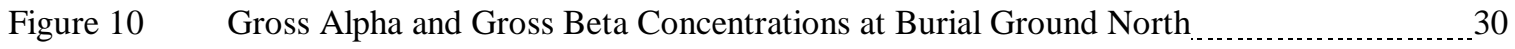

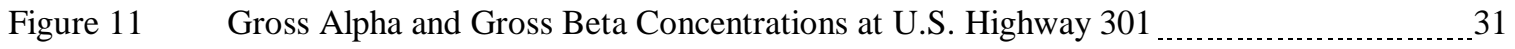

Figure 12 F-Area Filter Paper Co-60 (Weekly Sample) 32

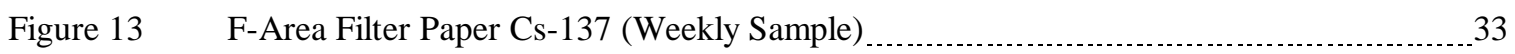

Figure 14 F-Area Filter Paper Gross Beta (Weekly Samples)

Figure 15 F-Area Filter Paper Gross Alpha (Weekly Samples)

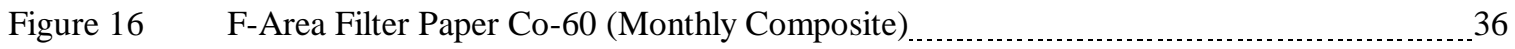

Figure $17 \quad$ F-Area Filter Paper Cs-137 (Monthly Composite) $\ldots \ldots \ldots \ldots$

Figure 18 F-Area Filter Paper Pu-238 (Monthly Composite)

Figure 19 F-Area Filter Paper Pu-239 (Monthly Composite) _........................................... 39

Figure 20 F-Area Filter Paper Sr-89,90 (Monthly Composite) $\ldots$

Figure 21 F-Area Charcoal Canister Co-60 (Weekly Samples)

Figure 22 F-Area Charcoal Canister Cs-137 (Weekly Samples)

Figure 23 F-Area Silica Gel H-3 (Biweekly Sample) _.................................................... 43

Figure 24 F-Area Rainwater H-3 (Biweekly Samples) 


\section{List of Figures (continued)}

Figure 25 Burial Ground North Filter Paper Co-60 (Weekly Sample) $\ldots \ldots \ldots \ldots$

Figure 26 Burial Ground North Filter Paper Cs-137 (Weekly Sample) _ 46

Figure 27 Burial Ground North Filter Paper U-234 (Annual Sample) _.................................... 47

Figure 28 Burial Ground North Filter Paper U-235 (Annual Sample)

Figure 29 Burial Ground North Filter Paper U-238 (Annual Sample) _ 49

Figure $30 \quad$ Burial Ground North Filter Paper Pu-238 (Annual Sample) $\ldots \ldots \ldots$

Figure 31 Burial Ground North Filter Paper Pu 239 (Annual Sample)

Figure 32 Burial Ground North Filter Paper Am-241 (Annual Sample)

Figure 33 Burial Ground North Filter Paper Cm-244 (Annual Sample) _.................................. 53

Figure 34 Burial Ground North Filter Paper Sr-89,90 (Annual Sample) _................................. 54

Figure $35 \quad$ Burial Ground North Filter Paper Gross Beta (Weekly Sample)

Figure 36 Burial Ground North Filter Paper Gross Alpha (Weekly Sample) _.............................. 56

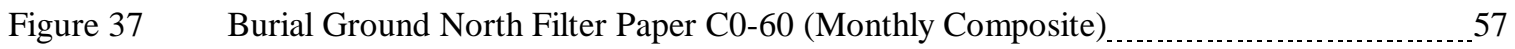

Figure 38 Burial Ground North Filter Paper Cs-137 (Monthly Composite) _ _ 58

Figure $39 \quad$ Burial Ground North Filter Paper Pu-238 (Monthly Composite)

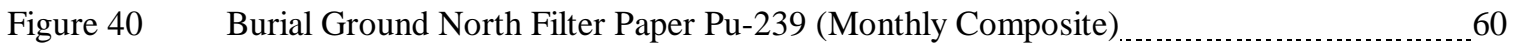

Figure $41 \quad$ Burial Ground North Filter Paper Sr-89,90 (Monthly Composite) _

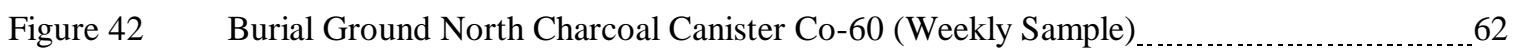

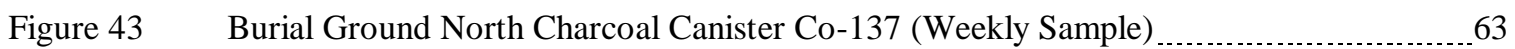

Figure 44 Burial Ground North Silica Gel H-3 (Bi-weekly Sample)

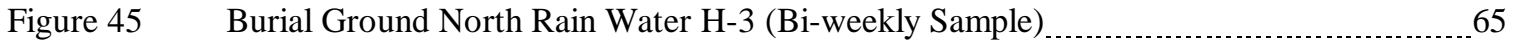

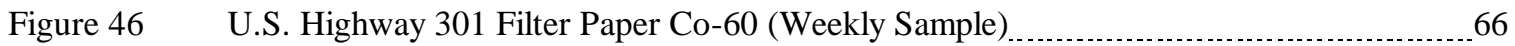

Figure 47 U.S. Highway 301 Filter Paper Co-137 (Weekly Sample) 67

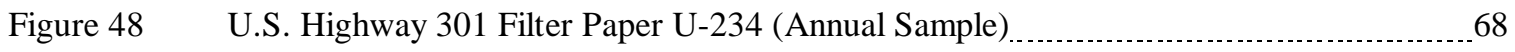

Figure 49 U.S. Highway 301 Filter Paper U-235 (Annual Sample) 


\section{List of Figures (continued)}

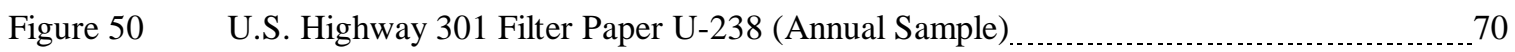

Figure $51 \quad$ U.S. Highway 301 Filter Paper Pu-238 (Annual Sample)

Figure 52 U.S. Highway 301 Filter Paper Pu-239 (Annual Sample) _.................................... 72

Figure 53 U.S. Highway 301 Filter Paper Am-241 (Annual Sample)

Figure 54 U.S. Highway 301 Filter Paper Cm-244 (Annual Sample) 74

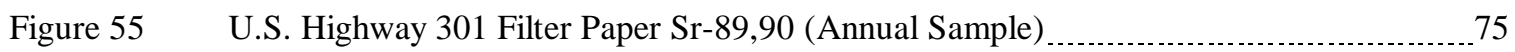

Figure 56 U.S. Highway 301 Filter Paper Gross Beta (Weekly Sample) $\ldots \ldots \ldots$

Figure 57 U.S. Highway 301 Filter Paper Gross Alpha (Weekly Sample)

Figure 58 U.S. Highway 301 Charcoal Canister Co-60 (Weekly Sample) $\ldots 78$

Figure 59 U.S. Highway 301 Charcoal Canister Cs-137 (Weekly Sample) _................................ 79

Figure 60 U.S. Highway 301 Silica Gel H-3 (Bi-weekly Sample) 80

Figure 61 U.S. Highway 301 Rain Water H-3 (Bi-weekly Sample)

Figure 62 Cs-137 Concentration in Soil (Near F-Area)

Figure 63 Sr-89-90 Concentration in Soil (Near F-Area) 83

Figure $64 \quad \mathrm{Pu}-238$ Concentration in Soil (Near F-Area)

Figure $65 \quad \mathrm{Pu}-239$ Concentration in Soil (Near F-Area) 


\section{Introduction}

This document provides an overview of existing environmental and ecological information at areas identified as potential locations of the Savannah River Site's (SRS) Surplus Plutonium Disposition (SPD) facilities. This information is required to document existing environmental and baseline conditions from which SPD construction and operation impacts can be defined. It will be used in developing the required preoperational monitoring plan to be used at specific SPD facilities construction sites. In general, the report is divided on the basis of exposure pathways. It has five sections, as follows:

1. General Information, which provides information on the SPD project

2. Radiological Monitoring, which describes the effluent monitoring and environmental surveillance monitoring programs and presents source term inventory and monitoring results, including both historical and current information

3. Nonradiological (Chemical) Monitoring, which defines major contaminants released from facilities impacting the SPD project area and presents an overview of monitoring activities

4. Groundwater Monitoring, which describes groundwater conditions and contaminants underlying the SPD project area

5. Other Considerations, which describes other issues which may impact the environment in the SPD project area 


\section{General Information}

\subsection{Project Description}

As a result of the end of the cold war in 1991, significant quantities of excess plutonium exist in both domestic and foreign stockpiles. As part of its stockpile stewardship responsibility, one mission of the U.S. Department of Energy (DOE) is to reduce the threat of nuclear weapons proliferation by disposing of surplus plutonium in the United States. This disposition must be completed in a timely and environmentally safe manner to ensure that surplus plutonium is converted into proliferation-resistant forms. DOE's disposition strategy allows for the immobilization of surplus plutonium and for its use as a mixed oxide fuel in existing domestic commercial power reactors.

The SPD project consists of the following types of facilities:

- A facility for disassembling pits (weapons components) and converting the recovered plutonium, as well as plutonium from other sources, into plutonium dioxide suitable for disposition. It is referred to as the Pit Disassembly and Conversion Facility (PDCF).

- A facility for immobilizing surplus plutonium for eventual disposal in a geologic repository, pursuant to the Nuclear Waste Policy Act. This facility will be able to convert nonpit plutonium materials into plutonium dioxide suitable for immobilization. It is referred to as the Plutonium Immobilization Plant (PIP).

- A facility for fabricating plutonium dioxide into a mixed oxide (MOX) fuel. This facility will be privately operated and licensed by the Nuclear Regulatory Commission. It is referred to as the MOX facility.

\subsection{Area Description}

The proposed sites for the SPD facilities are located along the existing F-Area perimeter, on the northeast and northwest sides. Six potential areas (including two supplemental areas) for facility construction have been identified for facility construction (figure 1, table 1). The PDCF will be located in Area X and the MOX fuel fabrication facility will be located in Areas 2 and 2A. The location of the PIP has not been determined.

The terrain of the areas under investigation is relatively level near the F-Area boundary. An unnamed tributary of Upper Three Runs originates in the general SPD project area. As the land descends to this tributary, fairly steep gradient drops are evident. Close to the F-Area boundary, the land is primarily cleared. Several areas include light industrial and administrative activities (office trailers, equipment storage areas, roads, and parking lots). Grass and shrubs are the primary vegetation in these areas. As the land approaches and drops to the Upper Three Runs tributary, the cover changes to thicker shrubs and forest.

\subsection{Waste Units}

Because of the SPD project's proximity to F-Area, areas of historical contamination may exist and are of interest. These could include both identified waste units and other areas of local increased contamination from facility operations and releases. In the SPD project area, a small number (12) of waste units and early construction and operation disposal (ECOD) sites have been identified. Table 2 and figure 2 provide details on these features.

\subsection{Groundwater}

Based on the groundwater flow patterns underlying the SPD site, the water table outcrops into Upper Three Runs and its tributaries (figure 3). The regional groundwater flow pattern for the deeper aquifers (Gordon and DublinMidville) is toward the Savannah River, and the overall pressure gradient in this area of the site is upward. As detailed elsewhere in this report, historical operations from E-Area and F-Area have resulted in groundwater contamination that impacts portions of the SPD project area. 


\subsection{Existing Monitoring Sites}

A number of active and inactive sampling sites are located in the SPD project area. These include wells and sampling sites for liquid, soil, and/or vegetation. Tables 3 and 4 and figures 3 and 4 provide details on these monitoring points within the SPD project area.

Primary sources of historical monitoring information include the annual SRS environmental reports and quarterly SRS groundwater monitoring reports. A series of reports that details the release of radionuclides-such as tritium, plutonium, and cesium - to the environment has been published by the Savannah River Technology Center (SRTC) and represents a dependable source of historical release information. 


\section{RADIOLOGICAL MONITORING}

\subsection{Inventory}

Routine manufacturing operations in F-Area have released quantities of material since operations began there in late 1954. Releases are documented in a series of technical reports issued by SRTC, in an EMS compilation of release data from 1954 to 1988, and in site environmental reports. Major contaminants released from operations include moderately- to long-lived fission products (primarily Cs-137 and Sr-89,90), isotopes of uranium (U-234, $\mathrm{U}-235$, and U-238), plutonium (Pu-238 and $\mathrm{Pu}-239)$, and other actinides (Am-241 and $\mathrm{Cm}-244)$. Only those radionuclides with a half-life greater than one year have been considered for this report; likewise, noble gasses have been excluded. Except for tritium, airborne releases through 1999 totaled approximately $739 \mathrm{Ci}$, and direct liquid releases to streams totaled approximately $768 \mathrm{Ci}$. Because of changes in F-Area operation requirements, release rates vary both by radionuclide and by year. The majority of activity was released before 1970; although actual release rates vary with radionuclide. Table 5 details the quantities of materials released from F-Area.

\subsection{Air Pathway}

Exposure vectors considered in the air pathway include the airborne release of material from F-Area and the deposition of airborne material. Air and soil samples collected and analyzed through EMS's air surveillance and soil surveillance programs represent the environmental media that indicate the impact of this material.

\subsubsection{Program Descriptions}

The SRS air surveillance program consists of monitoring locations in and around the site at which ambient air samples are collected. Changes in the program requirements have resulted in both the addition and the elimination of certain monitoring sites. Historically, the monitoring stations have been divided into four networks: on site, at the site perimeter, at the 25 -mile radius and at distant locations in major population centers. The media sampled by the air surveillance program consists of airborne particulates, volatiles, and atmospheric moisture.

In support of the SPD project, three monitoring sites are of particular interest--the F-Area, Burial Ground North, and Highway 301 stations. The F-Area site is located inside the F-Area fenceline on the northwest side. It is fairly close to SPD Area 1 and was operational until 1998. The Burial Ground North site is located along the outside of the old radioactive waste burial ground fenceline on the northwest side. It is fairly close to SPD Area 4 and has been operational since 1982. The Highway 301 site is located near the U.S. Highway 301 bridge across the Savannah River. It is in the least prevalent wind direction from SRS and represents the regional control site. It has been operational since 1965. Additional information about the SRS air surveillance program appears in the WSRC Environmental Monitoring Program document.

The SRS soil (deposition) program consists of monitoring locations in and around the site at which the deposition of airborne activity is measured. Changes in program requirements have resulted in both the addition and the elimination of certain monitoring sites. Historically, the media sampled has consisted of soil and/or rainwater.

In support of the SPD project, four soil monitoring locations are of particular interest - the F-Area $2000 \mathrm{E}$ (F-E), F-Area $2000 \mathrm{~W}$ (F-W), F-Area $2000 \mathrm{~N}$ (F-N), and F-Area 2000 S (F-S) sites. Also, soil sampling for a consistent regional background characterization was begun in 1997 at the U.S. Highway 301 station. The F-E soil site is located in SPD Area 2, approximately 2000 feet east of the F-Area main stack. It was operational from 1976 to 1995. The F-N soil site is located in SPD Area 5, approximately 2000 feet north of the F-Area main stack. It also was operational from 1976-1995. The F-W soil site is located approximately 2000 feet west of the F-Area main stack. It has been operational since 1976 . The F-S soil site is located approximately 2000 feet south of the F-Area main stack. It was operational from 1976 to 1996. Although the F-W and F-S sites are not located in the SPD project area, they provide additional information on soil radionuclide concentrations in the vicinity of F-Area that resulted from F-Area operations. Additional information about the SRS soil surveillance program appears in the WSRC Environmental Monitoring Program document. 


\subsubsection{Analytical Results}

Analytical results from the air and soil surveillance programs from 1965 through 1999 were examined. These results are presented in figures 6 through 65 . As with the numbers and locations of monitoring sites, changing program requirements and laboratory analytical capabilities have resulted in analytical protocols that vary from year to year. Based on the source term, environmental behavior, and exposure potential, key radionuclides are Sr89,90, Cs-137, Pu-238, and Pu-239; where available, gross alpha and gross beta results are useful in providing general trending information.

A special one-time survey of soil in F-Area was conducted in 1973, during which 10 locations were sampled. Although the exact locations of the samples cannot be determined, the survey provides additional information on radionuclide levels in soil in and around F-Area. Results of this survey are presented in table 6.

\subsection{Surface Water Pathway}

Exposure vectors considered in the surface water pathway include the direct liquid release of material from F-Area and the deposition of this material in stream beds. Liquid samples quantify the release and transport of the material, while sediment samples represent the indicating environmental media for long-term changes. These samples are collected and analyzed through EMS's liquid effluent, liquid surveillance, and sediment surveillance programs.

\subsubsection{Program Descriptions}

Overall, the liquid effluent program consists of a number of SRS monitoring sites at which samples of process discharge (effluent) water are collected. From these samples, the quantity of material directly released to the environment is determined. The liquid surveillance program consists of a number of monitoring sites located in and around SRS at which samples of stream and Savannah River water are collected. Generally, these sites are located downstream of a facility's process effluents, downstream of groundwater seeps, and downstream of the confluence of streams or tributaries with other tributaries, major streams, and/or the Savannah River. Changes in program requirements have resulted in both the addition and the elimination of certain monitoring.

In support of the SPD project, three monitoring sites are of particular interest-the Upper Three Runs-2 (U3R-2), Upper Three Runs-F3 (U3R-F3), and F-05 stations. Upper Three Runs-2 is an effluent monitoring site located in SPD Area 1 on the northwest side of F-Area. It receives nonprocess discharges and stormwater runoff from the northeast portion of F-Area. Upper Three Runs-F3 is an environmental surveillance monitoring site located in SPD Area 2 on the northwest side of F-Area. It receives stormwater runoff from the vicinity of the Naval Fuels Facility. The F-05 site is an environmental surveillance location located on the northeast side of F-Area and is located in SPD Area X. It receives nonprocess water and stormwater runoff from the northeast portion of F-Area. Additional information about the SRS liquid effluent and liquid surveillance programs appears in the WSRC Environmental Monitoring Program document.

The sediment surveillance program consists of sites located in and around SRS at which the deposition of waterborne activity is measured. Changes in program requirements have resulted in both the addition and the elimination of certain monitoring sites. No sediment monitoring stations have been located in or near the SPD project area. Additionally, no sediment monitoring stations are located near areas where tributaries associated with the SPD project discharge into Upper Three Runs.

\subsubsection{Analytical Results}

Analytical results from the liquid effluent and surveillance monitoring programs from 1965 through 1999 were examined. As with the numbers and locations of monitoring sites, changing program requirements and laboratory analytical capabilities have resulted in analytical protocols that vary from year to year. Most process-related activity released from F-Area was discharged to seepage basins. Specific monitoring results are not presented, but are summarized in table 5. These results show that the majority of activity released to streams was $\mathrm{H}-3$. Based on source term, environmental behavior, and exposure potential, key radionuclides are Sr-89,90, Cs-137, U-234, 
U-235, U-238, Pu-238, and Pu-239; where available, gross alpha and gross beta results are useful in providing general trending information.

\section{NONRADIOLOGICAL (CHEMICAL) MONITORING}

Information about releases of nonradiological material (chemicals) from F-Area is less detailed than it is about releases of radiological contaminants. Releases of chemicals from site facilities were examined during the first two phases of the SRS dose reconstruction project authorized by DOE and completed by the Centers for Disease Control in 1998. Although actual amounts released were not estimated, chemicals of specific concern which may result in offsite impacts were identified.

Chemicals released via the air pathway that were examined included ammonia, ammonia nitrate, benzene, chlorinated solvents, chromium, coal and coal ash, gasoline and other fuel oils, hydrazine mononitrate, hydrogen sulfide, lead, manganese compounds, mercury, nickel, nitric acid, oxides of nitrogen, sulfur dioxide, and uranium. Chemicals released via the liquid pathway that were considered included arsenic, cadmium, chromium, coal and coal ash, gasoline, hydrogen sulfide, lead, manganese, mercury, nickel, nitrates, uranium, and zinc. From these analyses, the following chemicals were identified as those released in quantities large that could have posed an adverse health effects: ammonia, nitrate, cadmium, chromium, hydrazine, mercury, manganese, nitric acid, and oxides of nitrogen.

SRS airborne releases are regulated to ensure compliance with the Clean Air Act, while the site's liquid releases are regulated to ensure compliance with the Clean Water Act as implemented by the National Pollutant Discharge Elimination System (NPDES). As indicated in tables 3 and 7, three active NPDES outfalls are located in the SPD project area. The constituents monitored at these outfalls are identified in table 7. From this, it may be assumed that F-Area processes have some potential to release and/or impact these constituents. 


\section{GROUNDWATER MONITORING}

Because of SRS operations, considerable groundwater contamination exists in the vicinity of separation and waste management areas. Sources of this contamination include buried material in E-Area and in seepage basins. Areas of concern in terms of the SPD project consist of the old F-Area seepage basin (located in SPD Area 1) and contamination originating from E-Area (which impacts SPD Areas 4 and 5). Figure 6 shows the extent of contaminated groundwater plumes, as indicated by tritium. As figure 6 shows, the most significant plume relating to the SPD project originates from the northwest portion of E-Area and has moved in a northwest direction towards Upper Three Runs. This plume impacts SPD Areas 4 and 5.

Figure 6 shows the extent of the tritium-contaminated groundwater plumes, but E-Area releases a variety of other contaminants as well. The extent of groundwater contamination by other materials depends on their mobility; tritium is the most mobile. The only other contaminant showing a significant plume impacting the SPD project area is volatile organic compounds (VOC), although the plume is much smaller. However, other contaminants may be present.

There are 76 wells in the SPD project area, of which 37 are active (table 4). Figure 3 shows the water contours and the locations of monitoring wells. Analytical results are from these wells are not included in this report, but they have been tabulated and are available electronically. In addition to tritium and VOCs, a number of other contaminants are found in one or more wells at concentrations above their respective limits as established by the U.S. Environmental Protection Agency in the Safe Drinking Water Act's primary drinking water standards. 


\section{OTHER CONSIDERATIONS}

Other environmental issues-such as unusual events/releases and ecological studies-were considered as part of this historical data summary. The major source of this information was personal conversations with individuals from a number of research, regulatory, and operational organizations.

A number of unusual operating events at F-Area have resulted in the unanticipated release of radioactive and/or nonradioactive material to the environment. Generally, the material was released to seepage basins (in the case of liquid releases) or was confined to the ground within F-Area (in the case of atmospheric releases). All known releases that may have impacted the environment have been categorized as known waste units or ECODs. No site evaluation units or documented events have resulted in contamination within the SPD project area (Gracy, 2000).

The SPD project area contains a diverse ecosystem, well suited to environmental and ecological research. However, neither SRTC nor the Savannah River Ecology Laboratory have indicated that active research is ongoing in the project area (Friday, 2000; Gladden, 2000; Hinton, 2000). 


\section{References}

Carlton, W.H., L. R. Bauer, A.G. Evans, L.A. Geary, C.E. Murphy, J.E. Pinder, and R.N. Storm, 1992a. Cesium in the Savannah River Site Environment. WSRC-RP-92-250.

Carlton, W.H., A.G. Evans, L.A. Geary, C.E. Murphy, and R.N. Storm, 1992b. Assessment of Strontium in the Savannah River Site Environment. WSRC-RP-92-984.

Carlton, W.H., A.G. Evans, L.A. Geary, C.E. Murphy, J.E. Pinder, and R.N. Storm, 1993a. Assessment of Plutonium in the Savannah River Site Environment. WSRC-RP-92-879.

Carlton, W.H., A.G. Evans, C.E. Murphy, and D.M. Tuck, 1993b. Assessment of Radiocarbon in the Savannah River Site Environment. WSRC-RP-93-215.

Carlton, W.H., M. Denham, and A.G. Evans, 1993c. Assessment of Technetium in the Savannah River Site Environment. WSRC-RP-93-217.

Du Pont, 1966. Environmental Monitoring at the Savannah River Plant, Annual Report-1965. DPST-66-302.

Du Pont, 1967. Environmental Monitoring at the Savannah River Plant, Annual Report-1966. DPST-67-302.

Du Pont, 1968. Environmental Monitoring at the Savannah River Plant, Annual Report-1967. DPST-68-302.

Du Pont, 1969. Environmental Monitoring at the Savannah River Plant, Annual Report-1968. DPST-69-302.

Du Pont, 1970. Environmental Monitoring at the Savannah River Plant, Annual Report-1969. DPST-70-302.

Du Pont, 1971. Environmental Monitoring at the Savannah River Plant, Annual Report-1970. DPST-71-302.

Du Pont, 1972. Environmental Monitoring at the Savannah River Plant, Annual Report-1971. DPSPU-72-302.

Du Pont, 1973. Environmental Monitoring at the Savannah River Plant, Annual Report-1972. DPSPU-73-302.

Du Pont, 1974. Environmental Monitoring at the Savannah River Plant, Annual Report-1973. DPSPU-74-302.

Du Pont, 1975. Environmental Monitoring at the Savannah River Plant, Annual Report-1974. DPSPU-75-302.

Du Pont, 1976. Environmental Monitoring at the Savannah River Plant, Annual Report-1975. DPSPU-76-302.

Du Pont, 1978a. Environmental Monitoring at the Savannah River Plant, Annual Report-1976. DPSPU-77-302.

Du Pont, 1978b. Environmental Monitoring at the Savannah River Plant, Annual Report-1977. DPSPU-78-302.

Du Pont, 1981. Environmental Monitoring at the Savannah River Plant, Annual Report-1978. DPSPU-79-302.

Du Pont, 1982. Environmental Monitoring at the Savannah River Plant, Annual Report-1979. DPSPU-80-302.

Du Pont, 1983. Environmental Monitoring at the Savannah River Plant, Annual Report-1980. DPSPU-81-302.

Du Pont, 1984a. Environmental Monitoring at the Savannah River Plant, Annual Report-1981. DPSPU-82-302.

Du Pont, 1984b. Environmental Monitoring at the Savannah River Plant, Annual Report-1982. DPSPU-83-302. 
Du Pont, 1984c. Environmental Monitoring at the Savannah River Plant, Annual Report-1983. DPSPU-84-302.

Du Pont, 1985. Environmental Monitoring at the Savannah River Plant, Annual Report-1984. DPSPU-85-302.

Du Pont, 1986a. Savannah River Plant Environmental Report for 1985. Volume I, Text. DPSPU-86-30-1.

Du Pont, 1986b. Savannah River Plant Environmental Report for 1985. Volume II, Figures and Data Tables. DPSPU-86-30-1.

Du Pont, 1987a. Savannah River Plant Environmental Report, Annual Report for 1986. Volume I, Text. DPSPU87-30-1.

Du Pont, 1987b. Savannah River Plant Environmental Report, Annual Report for 1986. Volume II, Figures and Data Tables. DPSPU-87-30-1.

Du Pont, 1988a. Savannah River Plant Environmental Report, Annual Report for 1987. Volume I, Text. DPSPU88-30-1.

Du Pont, 1988b. Savannah River Plant Environmental Report, Annual Report for 1987. Volume II, Figures and Data Tables. DPSPU-88-30-1.

Evans, A.G., L.R. Bauer, J.S. Haselow, D.W. Hayes, H.L. Martin, W.L. McDowell, and J.B. Pickett, 1992. Uranium in the Savannah River Site Environment. WSRC-RP-92-315.

Friday, G., 2000. Personal conversation with Gary Friday (Savannah River Technology Center: Environmental Science and Technology Section), March 21, 2000.

Gladden, J., 2000. Personal conversation with John Gladden (Savannah River Technology Center: Environmental Science and Technology Section), March 21, 2000.

Gracy, D., 2000. Persomnal conversation with Dennis Gracy (Nuclear Material Stabilization Program: Environmental and OSHA Engineering), March 8, 2000.

Hetrick, C.S. and D.K. Martin, 1990. Radioactive Releases at the Savannah River Site, 1954-1988. WSRC-RP89-737.

Hinton, T., 2000. Personal conversation with Tom Hinton (Savannah River Ecology Laboratory), April 6, 2000.

Kantello, M.V., L. R. Bauer, W.L. Marter, C.E. Murphy, and C.C. Zeigler, 1993. Radioiodine in the Savannah River Site Environment. WSRC-RP-90-424-2.

Murphy, C.E., W.H. Carlton, L.R. Bauer, D.W. Hayes, W.L.Marter, C.C. Zeigler, R.L. Nichols, R.N. Storm, B.R. del Carmen, D.M. Hamby, D.D. Hoel, and D.E. Stephenson, 1991. Assessment of Tritium in the Savannah River Site Environment. WSRC-RP-93-214.I

Risk Assessment Corporation, 1999. Savannah River Site Environmental Dose Reconstruction Project Phase II: Source Term Calculation and Ingestion Pathway Data Retrieval Evaluation of Materials Released from the Savannah River Site, draft final report. RAC report 1-CDC-SRS-1999-Draft Final.

Westinghouse Savannah River Company, 1989a. Savannah River Site Environmental Report for 1988. Volume I, Text. WSRC-RP-89-59-1. 
Westinghouse Savannah River Company, 1989b. Savannah River Site Environmental Report for 1988(U). Volume II, Figures and Data Tables. WSRC-RP-89-59-1.

Westinghouse Savannah River Company, 1990. Savannah River Site Environmental Report for 1989. Annual Report for 1989. Vol. I and II. WSRC-IM-90-60.

Westinghouse Savannah River Company, 1991. Savannah River Site Environmental Report. Annual Report for 1990. Volume I, Environmental Monitoring Compliance and Research, Volume II Groundwater Monitoring. WSRC-IM-91-28.

Westinghouse Savannah River Company, 1992. Savannah River Site Environmental Report for 1991. WSRC-TR92-186.

Westinghouse Savannah River Company, 1993a. Savannah River Site Environmental Report for 1992. WSRC-TR-93-075.

Westinghouse Savannah River Company, 1993b. Savannah River Site Environmental Data for 1992. WSRC-TR-93-077.

Westinghouse Savannah River Company, 1994a. Savannah River Site Environmental Report for 1993. WSRC-TR-94-075.

Westinghouse Savannah River Company, 1994b. Savannah River Site Environmental Data for 1993. WSRC-TR-94-077.

Westinghouse Savannah River Company, 1995a. Savannah River Site Environmental Report for 1994. WSRC-TR-95-075.

Westinghouse Savannah River Company, 1995b. Savannah River Site Environmental Data for 1994. WSRC-TR-95-077.

Westinghouse Savannah River Company, 1996a. Savannah River Site Environmental Report for 1995. WSRC-TR-96-0075.

Westinghouse Savannah River Company, 1996b. Savannah River Site Environmental Data for 1995. WSRC-TR-96-0077.

Westinghouse Savannah River Company, 1997a. Savannah River Site Environmental Report for 1996. WSRC-TR-97-0075.

Westinghouse Savannah River Company, 1997b. Savannah River Site Environmental Data for 1996. WSRC-TR-97-0077.

Westinghouse Savannah River Company, 1998a. Savannah River Site Environmental Report for 1997. WSRC-TR-97-00322.

Westinghouse Savannah River Company, 1998a. Savannah River Site Environmental Data for 1997. WSRC-TR-97-00324.

Westinghouse Savannah River Company, 1999a. Savannah River Site Environmental Report for 1998. WSRC-TR-98-00312.

Westinghouse Savannah River Company, 1999b. Savannah River Site Environmental Data for 1998. WSRC-TR-98-00314. 
Westinghouse Savannah River Company, 1999c. Savannah River Site Environmental Monitoring Section Plans and Procedures. WSRC-3Q1-2, Volume 1, Section 1100.

Westinghouse Savannah River Company, 2000a. Savannah River Site Environmental Report for 1999. WSRC-TR-99-00299.

Westinghouse Savannah River Company, 2000b. Savannah River Site Environmental Data for 1999. WSRC-TR-99-00301. 
TABLE 1

SPD Project Potential Construction Sites

\begin{tabular}{|c|c|c|}
\hline Location & Area (acres) & Area $\left.\mathbf{( m}^{\mathbf{2}}\right)$ \\
\hline$X$ & 25.36 & $1.026 \mathrm{e}+5$ \\
\hline 1 & 25.09 & $1.015 \mathrm{e}+5$ \\
\hline 2 & 24.81 & $1.004 \mathrm{e}+5$ \\
\hline $2 \mathrm{~A}$ & 8.04 & $3.254 \mathrm{e}+4$ \\
\hline 3 & 25.09 & $1.015 \mathrm{e}+5$ \\
\hline 4 & 45.85 & $1.855 \mathrm{e}+5$ \\
\hline 5 & 25.09 & $1.015 \mathrm{e}+5$ \\
\hline $5 \mathrm{~A}$ & 17.50 & $7.085 \mathrm{e}+4$ \\
\hline
\end{tabular}


Table 2

Waste Units and ECODs within the SPD Project Area

\begin{tabular}{|c|l|c|c|}
\hline $\begin{array}{c}\text { Waste } \\
\text { Unit ID }\end{array}$ & \multicolumn{1}{|c|}{ Waste Unit Name } & $\begin{array}{c}\text { Index } \\
\text { Number }\end{array}$ & $\begin{array}{c}\text { SPD } \\
\text { Construction } \\
\text { Area }\end{array}$ \\
\hline $474-3$ & General Area, Other: Process and Sewer Lines as Abandoned, NBN & 474 & 1 \\
\hline 105 & Old F-Area Seepage Basin, 904-49G & 105 & 1 \\
\hline $523-1$ & ECODS F-1 (Southeast of F-Ash Basin, 276-0F) & 523 & 4 \\
\hline $523-2$ & ECODS F-1 (Southeast of F-Ash Basin, 276-0F) & 523 & 4 \\
\hline $523-4$ & ECODS F-1 (Southeast of F-Ash Basin, 276-0F) & 523 & 4 \\
\hline $523-5$ & ECODS F-1 (Southeast of F-Ash Basin, 276-0F) & 523 & 4 \\
\hline 276 & F-Area Ash Basin, 288-0F & 276 & 4,5 \\
\hline $16-2$ & $\begin{array}{l}\text { Mixed Waste Management Facility (including the RCRA Regulated } \\
\text { Portions of LLRWF 643-7E), 643-28E }\end{array}$ & 16 & 5 \\
\hline 2 & F-Area Acid Caustic Basin, 904-47G & 2 & $5 \mathrm{~A}$ \\
\hline 284 & F-Area Acid/Caustic Basin (Groundwater) & 284 & $5 \mathrm{~A}$ \\
\hline 277 & F-Area Ash Basin, 288-1F & 277 & $5 \mathrm{~A}$ \\
\hline 71 & F-Area Coal Pile Runoff Basin, 289-F & 71 & $5 \mathrm{~A}$ \\
\hline
\end{tabular}


TABLE 3

Monitoring Locations within the SPD Project Area

\begin{tabular}{|l|c|c|c|}
\hline Sampling Point Name & Monitoring Program & Status & $\begin{array}{c}\text { SPD Construction } \\
\text { Area }\end{array}$ \\
\hline F-02 & NPDES & Active & 1 \\
\hline Upper Three Runs-2 & RAD Liquid Effluent & Active & 1 \\
\hline F-03 & NPDES & Active & 2 \\
\hline F-Area North & RAD Soil Surveillance & Inactive & 2 \\
\hline Upper Three Runs-F3 & RAD Liquid Surveillance & Active & 2 \\
\hline F-007 & NPDES & Inactive & 4 \\
\hline F-Area East & RAD Soil Surveillance & Inactive & 5 \\
\hline OBG-2 & RAD Vegetation Surveillance & Inactive & 5 \\
\hline F-05 & NPDES & Active & X \\
\hline F-05 & RAD ALARA & Active & X \\
\hline
\end{tabular}


Table 4

Monitoring Wells within the SPD Project Area

\begin{tabular}{|c|c|c|c|c|c|}
\hline Well Name & Type & Date Installed & $\begin{array}{c}\text { Date } \\
\text { Abandoned }\end{array}$ & Catalog ID & $\begin{array}{c}\text { SPD } \\
\text { Construction } \\
\text { Area }\end{array}$ \\
\hline FNB 1 & $\mathrm{Mw}$ & $8 / 9 / 83$ & & FNB1 & 1 \\
\hline FNB 1A & $\mathrm{Mw}$ & $11 / 17 / 93$ & & FNB1A & 1 \\
\hline ZW 20 & & & & ZW20 & 2 \\
\hline BG 93 & $\mathrm{Ab}, \mathrm{Mw}$ & $10 / 12 / 81$ & $1 / 22 / 97$ & BG93 & 3 \\
\hline DRB 1WW & $\mathrm{Sp}$ & $2 / 1 / 61$ & & DRB1WW & 3 \\
\hline F 51 & $\mathrm{Ab}$ & $5 / 18 / 67$ & 1978 & F51 & 3 \\
\hline HMD 2D & $\mathrm{Mw}$ & $2 / 1 / 91$ & & HMD2D & 3 \\
\hline BG 122 & $\mathrm{Ab}, \mathrm{Mw}$ & & $1 / 21 / 97$ & BG122 & 4 \\
\hline BG 125 & $\mathrm{Ab}, \mathrm{Mw}$ & & $1 / 23 / 97$ & BG125 & 4 \\
\hline BG 38 & $\mathrm{Ab}, \mathrm{Mw}$ & $5 / 24 / 76$ & $4 / 25 / 88$ & BG38 & 4 \\
\hline BG 39 & $\mathrm{Ab}, \mathrm{Mw}$ & $5 / 25 / 76$ & $4 / 22 / 88$ & BG39 & 4 \\
\hline BG 91 & $\mathrm{Ab}, \mathrm{Mw}$ & $10 / 6 / 81$ & $1 / 21 / 97$ & BG91 & 4 \\
\hline BG 92 & $\mathrm{Ab}, \mathrm{Mw}$ & $10 / 8 / 81$ & $1 / 22 / 97$ & BG92 & 4 \\
\hline BGO 11D & $\mathrm{Ab}, \mathrm{Mw}$ & $8 / 24 / 87$ & $11 / 1 / 95$ & BGO11D & 4 \\
\hline BGO 11DR & $\mathrm{Mw}$ & $9 / 7 / 95$ & & BGO11DR & 4 \\
\hline BGO 12A & $\mathrm{Ab}, \mathrm{Mw}$ & $10 / 2 / 87$ & $11 / 1 / 95$ & BGO12A & 4 \\
\hline BGO 12AR & $\mathrm{Ab}, \mathrm{Mw}$ & $2 / 21 / 91$ & $1 / 26 / 96$ & BGO12AR & 4 \\
\hline BGO 12AX & $\mathrm{Mw}$ & $10 / 3 / 95$ & & BGO12AX & 4 \\
\hline BGO 12C & $\mathrm{Ab}, \mathrm{Mw}$ & $10 / 1 / 87$ & $2 / 25 / 92$ & BGO12C & 4 \\
\hline BGO 12CR & $\mathrm{Ab}, \mathrm{Mw}$ & $3 / 18 / 91$ & $1 / 26 / 96$ & BGO12CR & 4 \\
\hline BGO 12CX & $\mathrm{Mw}$ & 9/29/95 & & BGO12CX & 4 \\
\hline BGO 12D & $\mathrm{Ab}, \mathrm{Mw}$ & $9 / 29 / 87$ & $11 / 1 / 95$ & BGO12D & 4 \\
\hline BGO 12DR & $\mathrm{Mw}$ & $9 / 12 / 95$ & & BGO12DR & 4 \\
\hline BGO 43A & $\mathrm{Mw}$ & $4 / 26 / 91$ & & BGO43A & 4 \\
\hline BGO 43AA & $\mathrm{Mw}$ & $4 / 1 / 91$ & & BGO43AA & 4 \\
\hline BGO 43CR & $\mathrm{Mw}$ & $6 / 6 / 91$ & & BGO43CR & 4 \\
\hline BGO 43D & $\mathrm{Mw}$ & $4 / 29 / 91$ & & BGO43D & 4 \\
\hline F 43 & $\mathrm{Ab}$ & $2 / 13 / 67$ & 1978 & $\mathrm{~F} 43$ & 4 \\
\hline F 55 & & 9/19/67 & & F55 & 4 \\
\hline F 56 & & $10 / 25 / 67$ & & F56 & 4 \\
\hline $\begin{array}{ll}\mathrm{F} & 57 \mathrm{~A}\end{array}$ & $\mathrm{Ab}$ & $10 / 30 / 67$ & 1978 & F57A & 4 \\
\hline $\begin{array}{ll}\mathrm{F} & 57 \mathrm{~B} \\
\end{array}$ & $\mathrm{Ab}$ & $11 / 8 / 67$ & 1978 & F57B & 4 \\
\hline F $57 \mathrm{C}$ & $\mathrm{Ab}$ & $11 / 8 / 67$ & 1978 & F57C & 4 \\
\hline F 58 & $\mathrm{Ab}$ & $11 / 16 / 67$ & 1978 & F58 & 4 \\
\hline F 59 & & $12 / 4 / 67$ & & F59 & 4 \\
\hline ZW 4 & $\mathrm{Ab}, \mathrm{Mw}$ & $9 / 7 / 51$ & $1 / 27 / 97$ & ZW4 & 4 \\
\hline BG 40 & $\mathrm{Ab}, \mathrm{Mw}$ & $5 / 26 / 76$ & $4 / 21 / 88$ & BG40 & 5 \\
\hline BGO 13D & $\mathrm{Mw}$ & $10 / 12 / 87$ & & BGO13D & 5 \\
\hline BGO 13DR & $\mathrm{Mw}$ & $2 / 27 / 91$ & & BGO13DR & 5 \\
\hline FAC 6P & $\mathrm{Pz}$ & $2 / 3 / 92$ & & FAC6P & 5 \\
\hline FAC 7 & $\mathrm{Ab}, \mathrm{Mw}$ & $9 / 15 / 88$ & $4 / 4 / 96$ & FAC7 & 5 \\
\hline FAC 8 & $\mathrm{Ab}, \mathrm{Mw}$ & $9 / 9 / 88$ & $4 / 4 / 96$ & FAC8 & 5 \\
\hline FAC 9C & $\mathrm{Mw}$ & $6 / 21 / 94$ & & FAC9C & 5 \\
\hline
\end{tabular}


Table 4 (continued)

Monitoring Wells within the SPD Project Area

\begin{tabular}{|c|c|c|c|c|c|}
\hline Well Name & Type & Date Installed & $\begin{array}{c}\text { Date } \\
\text { Abandoned }\end{array}$ & Catalog ID & $\begin{array}{c}\text { SPD } \\
\text { Construction } \\
\text { Area }\end{array}$ \\
\hline MZ 6 & $\mathrm{Ab}$ & & $1 / 27 / 97$ & MZ6 & 5 \\
\hline BG 13 & & $6 / 1 / 61$ & & BG13 & $5 \mathrm{~A}$ \\
\hline BG 14 & & $5 / 26 / 61$ & & BG14 & $5 \mathrm{~A}$ \\
\hline FAB 1 & $\mathrm{Mw}$ & $5 / 13 / 94$ & & FAB1 & $5 \mathrm{~A}$ \\
\hline FAB 2 & $\mathrm{Mw}$ & $5 / 9 / 94$ & & FAB2 & $5 \mathrm{~A}$ \\
\hline FAB 3 & $\mathrm{Mw}$ & $5 / 12 / 94$ & & FAB3 & $5 \mathrm{~A}$ \\
\hline FAB 4 & $\mathrm{Mw}$ & $5 / 10 / 94$ & & FAB4 & $5 \mathrm{~A}$ \\
\hline FAC 1P & $\mathrm{Ab}, \mathrm{Pz}$ & $1 / 28 / 92$ & $4 / 11 / 96$ & FAC1P & $5 \mathrm{~A}$ \\
\hline FAC 2 & $\mathrm{Ab}, \mathrm{Mw}$ & $8 / 24 / 83$ & $3 / 10 / 89$ & FAC2 & $5 \mathrm{~A}$ \\
\hline FAC 3 & $\mathrm{Ab}, \mathrm{Mw}$ & $8 / 26 / 83$ & $4 / 4 / 96$ & FAC3 & $5 \mathrm{~A}$ \\
\hline FAC 3P & $\mathrm{Ab}, \mathrm{Pz}$ & $1 / 21 / 92$ & $4 / 4 / 96$ & FAC3P & $5 \mathrm{~A}$ \\
\hline FAC 4P & $\mathrm{Ab}, \mathrm{Pz}$ & $1 / 21 / 92$ & $4 / 4 / 96$ & FAC4P & $5 \mathrm{~A}$ \\
\hline FAC 5 & $\mathrm{Ab}, \mathrm{Mw}$ & $9 / 2 / 88$ & $4 / 4 / 96$ & FAC5 & $5 \mathrm{~A}$ \\
\hline FAC 6 & $\mathrm{Ab}, \mathrm{Mw}$ & $9 / 15 / 88$ & $4 / 4 / 96$ & FAC6 & $5 \mathrm{~A}$ \\
\hline FAC 10C & $\mathrm{Mw}$ & $6 / 21 / 94$ & & FAC10C & $5 \mathrm{~A}$ \\
\hline FAC 11C & $\mathrm{Ab}, \mathrm{Mw}$ & $6 / 24 / 94$ & $4 / 4 / 96$ & FAC11C & $5 \mathrm{~A}$ \\
\hline FAC 12C & $\mathrm{Ab}, \mathrm{Mw}$ & $6 / 24 / 94$ & $4 / 4 / 96$ & FAC12C & $5 \mathrm{~A}$ \\
\hline FCB 1 & $\mathrm{Ab}, \mathrm{Mw}$ & $10 / 16 / 81$ & $7 / 13 / 88$ & FCB1 & $5 \mathrm{~A}$ \\
\hline FCB 7 & $\mathrm{Mw}$ & $7 / 7 / 88$ & & FCB7 & $5 \mathrm{~A}$ \\
\hline FAC 2P & $\mathrm{Ab}, \mathrm{Pz}$ & $1 / 28 / 92$ & $4 / 3 / 96$ & FAC2P & $\mathrm{X}$ \\
\hline FAC 4 & $\mathrm{Ab}, \mathrm{Mw}$ & $7 / 20 / 84$ & $4 / 3 / 96$ & FAC4 & $\mathrm{X}$ \\
\hline FC $2 \mathrm{~A}$ & & $4 / 1 / 77$ & & FC2A & $\mathrm{X}$ \\
\hline FC $2 \mathrm{~B}$ & & $4 / 7 / 77$ & & FC2B & $X$ \\
\hline FC $2 \mathrm{C}$ & & $4 / 14 / 77$ & & FC2C & $X$ \\
\hline $\begin{array}{ll}\mathrm{FC} & 2 \mathrm{D}\end{array}$ & & $4 / 18 / 77$ & & FC2D & $\mathrm{X}$ \\
\hline $\begin{array}{ll}\text { FC } & 2 \mathrm{E} \\
\end{array}$ & & $4 / 21 / 77$ & & FC2E & $\mathrm{X}$ \\
\hline FC $2 \mathrm{~F}$ & & $4 / 22 / 77$ & & $\mathrm{FC} 2 \mathrm{~F}$ & $\mathrm{X}$ \\
\hline $\begin{array}{ll}\mathrm{P} & 28 \mathrm{~A} \\
\end{array}$ & $\mathrm{Mw}$ & $9 / 27 / 86$ & & P28A & $\mathrm{X}$ \\
\hline $\begin{array}{ll}\mathrm{P} & \text { 28TA } \\
\end{array}$ & $\mathrm{Mw}$ & $7 / 8 / 86$ & & P28TA & $X$ \\
\hline P $28 \mathrm{~TB}$ & $\mathrm{Mw}$ & $10 / 2 / 86$ & & $\mathrm{P} 28 \mathrm{~TB}$ & $X$ \\
\hline $\mathrm{P} \quad 28 \mathrm{TC}$ & $\mathrm{Mw}$ & $10 / 7 / 86$ & & P28TC & $\mathrm{X}$ \\
\hline $\mathrm{P} \quad$ 28TD & Mw & $10 / 9 / 86$ & & P28TD & $X$ \\
\hline P 28TE & $\mathrm{Mw}$ & $10 / 14 / 86$ & & P28TE & $\mathrm{X}$ \\
\hline
\end{tabular}

Mw: monitoring well

Ab: abandoned

Pz: piezometer

Sp: special 
Table 5

Inventory of Radionuclides Released from F-Area

\begin{tabular}{|l|l|l|}
\hline Radionuclide & $\begin{array}{l}\text { Liquid } \\
\text { Release }(\mathrm{Ci})^{1}\end{array}$ & $\begin{array}{l}\text { Airborne } \\
\text { Release (Ci) }{ }^{1}\end{array}$ \\
\hline Am-241 & $1.85 \mathrm{e}-5$ & $4.68 \mathrm{e}-3$ \\
\hline C-14 & & $6.48 \mathrm{e}+2$ \\
\hline Cm-244 & $7.28 \mathrm{e}-6$ & $5.35 \mathrm{e}-3$ \\
\hline Co-60 & & $1.91 \mathrm{e}-2$ \\
\hline Cs-134 & & $8.56 \mathrm{e}-4$ \\
\hline Cs-137 & $1.00 \mathrm{e}+0$ & $5.97 \mathrm{e}-1$ \\
\hline Eu-154 & & $5.21 \mathrm{e}-7$ \\
\hline H-3 & $7.50 \mathrm{e}+2$ & See note \\
\hline I-129 & & $1.92 \mathrm{e}-2^{3}$ \\
\hline Pm-147 & $6.13 \mathrm{e}-2$ & \\
\hline Pu-238 & $3.80 \mathrm{e}-5$ & $1.46 \mathrm{e}-2$ \\
\hline Pu-239 & $9.28 \mathrm{e}-4$ & $2.44 \mathrm{e}+0$ \\
\hline Ru-103,106 & & $3.85 \mathrm{e}+1$ \\
\hline Ru-106 & & $3.29 \mathrm{e}+1$ \\
\hline Sb-125 & & $2.93 \mathrm{e}-3$ \\
\hline Sr-89,90 & $3.69 \mathrm{e}-2$ & $6.76 \mathrm{e}-1$ \\
\hline Sr-90 & $2.95 \mathrm{e}-1$ & \\
\hline U (nat) & $5.95 \mathrm{e}-5$ & $5.80 \mathrm{e}-1$ \\
\hline U-234 & $2.13 \mathrm{e}-4$ & $4.02 \mathrm{e}-4$ \\
\hline U-235 & $1.65 \mathrm{e}-5$ & $2.07 \mathrm{e}-3$ \\
\hline U-238 & $4.17 \mathrm{e}-4$ & $2.03 \mathrm{e}-3$ \\
\hline Unidentified Alpha & \\
\hline Unidentified Beta & & $7.41 \mathrm{e}-2$ \\
\hline & $2.90 \mathrm{e}-1$ & $1.53 \mathrm{e}+1$ \\
\hline & $1.63 \mathrm{e}+1$ & \\
\hline
\end{tabular}

Notes

${ }^{1}$ Blanks indicate either no quantifiable activity or monitoring for the radionuclide is not conducted.

${ }^{2}$ Airborne releases of tritium from F-Area and H-Area are combined

${ }^{3}$ Releases from F-Area and H-Area combined until 1991.

${ }^{4}$ Assumed to be $\mathrm{Pu}-239$

${ }^{5}$ Assumed to be $\mathrm{Sr}-89,90$ 
Table 6

1973 F-Area Special Soil Survey

Results in $\mathbf{p C i} / \mathrm{g}$

\begin{tabular}{|c|c|c|c|c|}
\hline Location & Cs-137 & Sr-90 & Pu-238 & Pu-239 \\
\hline 1 & $3.90 \mathrm{E}-01$ & $3.20 \mathrm{E}-01$ & $4.66 \mathrm{E}-02$ & $3.70 \mathrm{E}-02$ \\
\hline 2 & $3.70 \mathrm{E}-01$ & $4.58 \mathrm{E}-01$ & $1.00 \mathrm{E}-03$ & $3.13 \mathrm{E}-02$ \\
\hline 9 & $5.00 \mathrm{E}-01$ & $2.88 \mathrm{E}-01$ & $3.00 \mathrm{E}-03$ & $3.39 \mathrm{E}-02$ \\
\hline 10 & $5.00 \mathrm{E}-01$ & $4.80 \mathrm{E}-02$ & $9.72 \mathrm{E}-02$ & $3.75 \mathrm{E}-02$ \\
\hline 11 & $3.10 \mathrm{E}-01$ & $1.18 \mathrm{E}-01$ & $6.80 \mathrm{E}-03$ & $1.15 \mathrm{E}-01$ \\
\hline 12 & $3.80 \mathrm{E}-01$ & $3.08 \mathrm{E}-01$ & $7.20 \mathrm{E}-03$ & $1.64 \mathrm{E}-01$ \\
\hline 13 & $4.00 \mathrm{E}-01$ & $5.70 \mathrm{E}-02$ & $4.00 \mathrm{E}-03$ & $5.32 \mathrm{E}-02$ \\
\hline 14 & $2.50 \mathrm{E}-01$ & $1.62 \mathrm{E}-01$ & $2.80 \mathrm{E}-03$ & $1.40 \mathrm{E}-02$ \\
\hline 15 & $5.50 \mathrm{E}-01$ & $3.88 \mathrm{E}-01$ & not detected & $9.36 \mathrm{E}-02$ \\
\hline 16 & $3.20 \mathrm{E}-01$ & $1.40 \mathrm{E}-01$ & $4.80 \mathrm{E}-03$ & $2.89 \mathrm{E}-02$ \\
\hline
\end{tabular}


Table 7

Current NPDES Monitoring Requirements

\begin{tabular}{|l|l|}
\hline Outfall & $\begin{array}{l}\text { Measurement and } \\
\text { Monitoring Parameters }\end{array}$ \\
\hline F-02 & Flow \\
& $\begin{array}{l}\text { Total suspended solids } \\
\text { Temperature } \\
\text { pH }\end{array}$ \\
\hline F-03 & Flow \\
& Total suspended solids \\
& Temperature \\
& pH \\
& Lead \\
\hline F-05 & Flow \\
& Total suspended solids \\
& Temperature \\
& pH \\
& Oil and grease \\
\hline
\end{tabular}


Figure 1

SPD Project Areas with Topography (20' Contours)

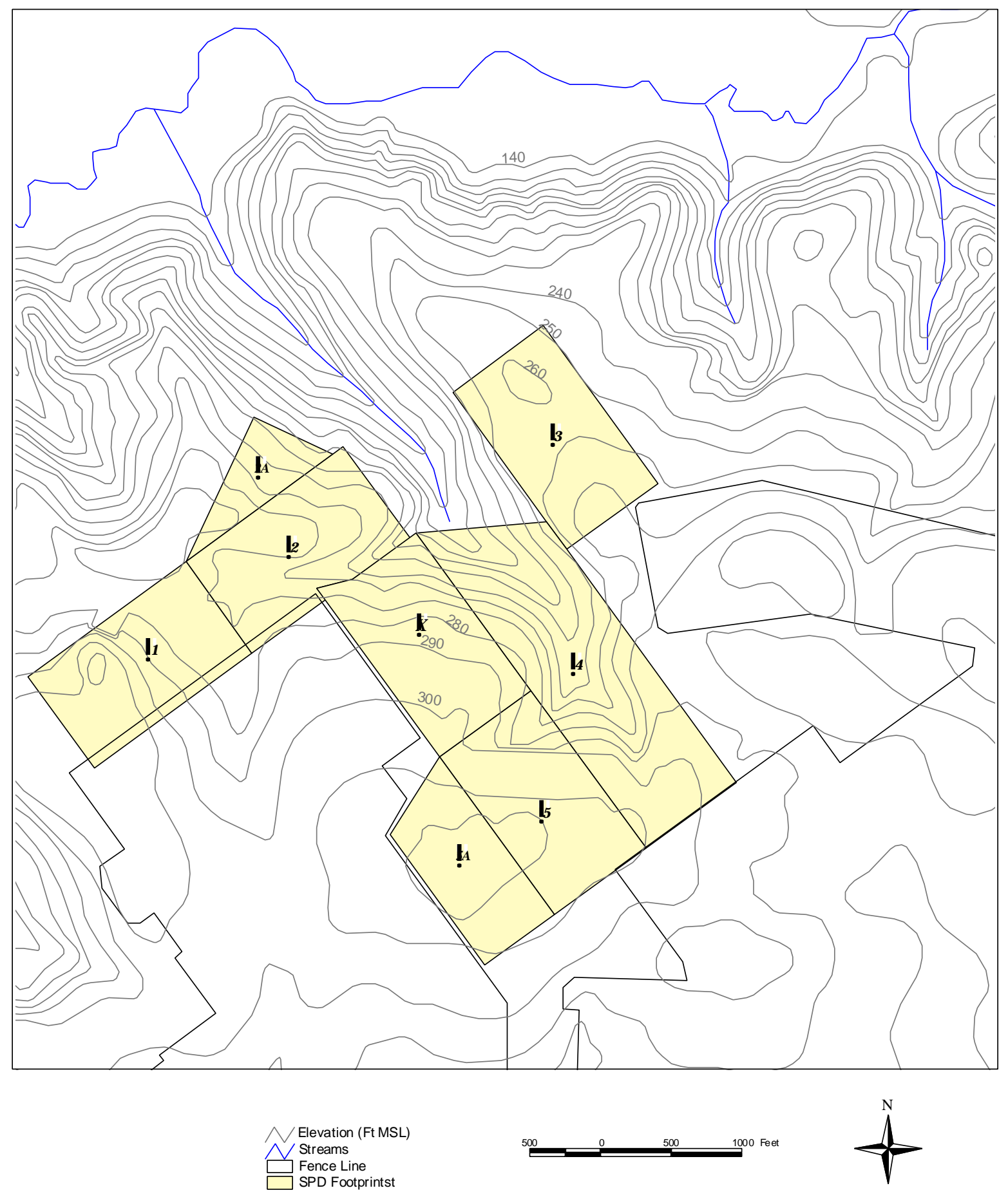


Figure 2

Identified Waste Units and ECODs

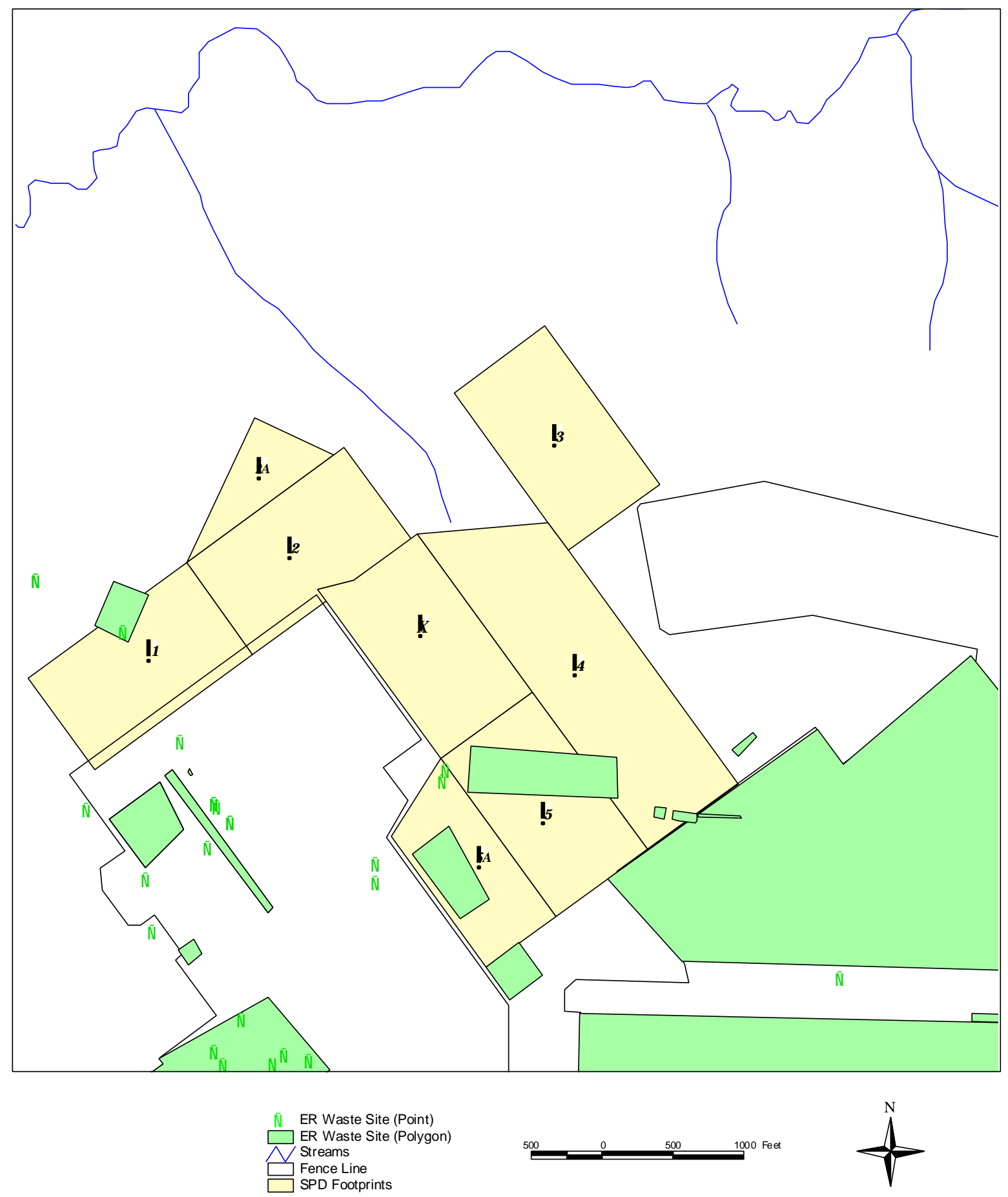


Figure 3

Water Table Elevation and Well Locations
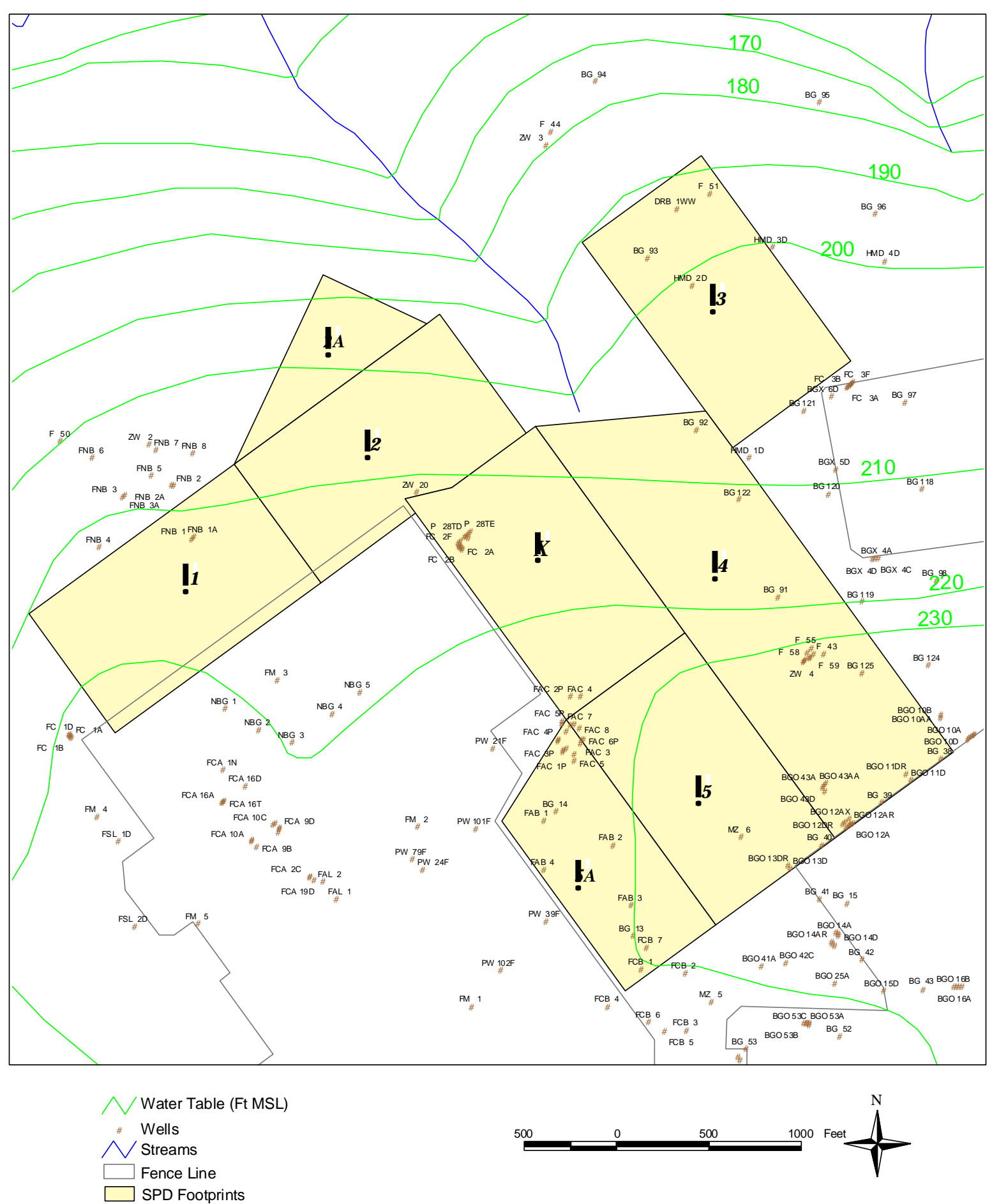
Figure 4

\section{Routine EMS Monitoring Locations}

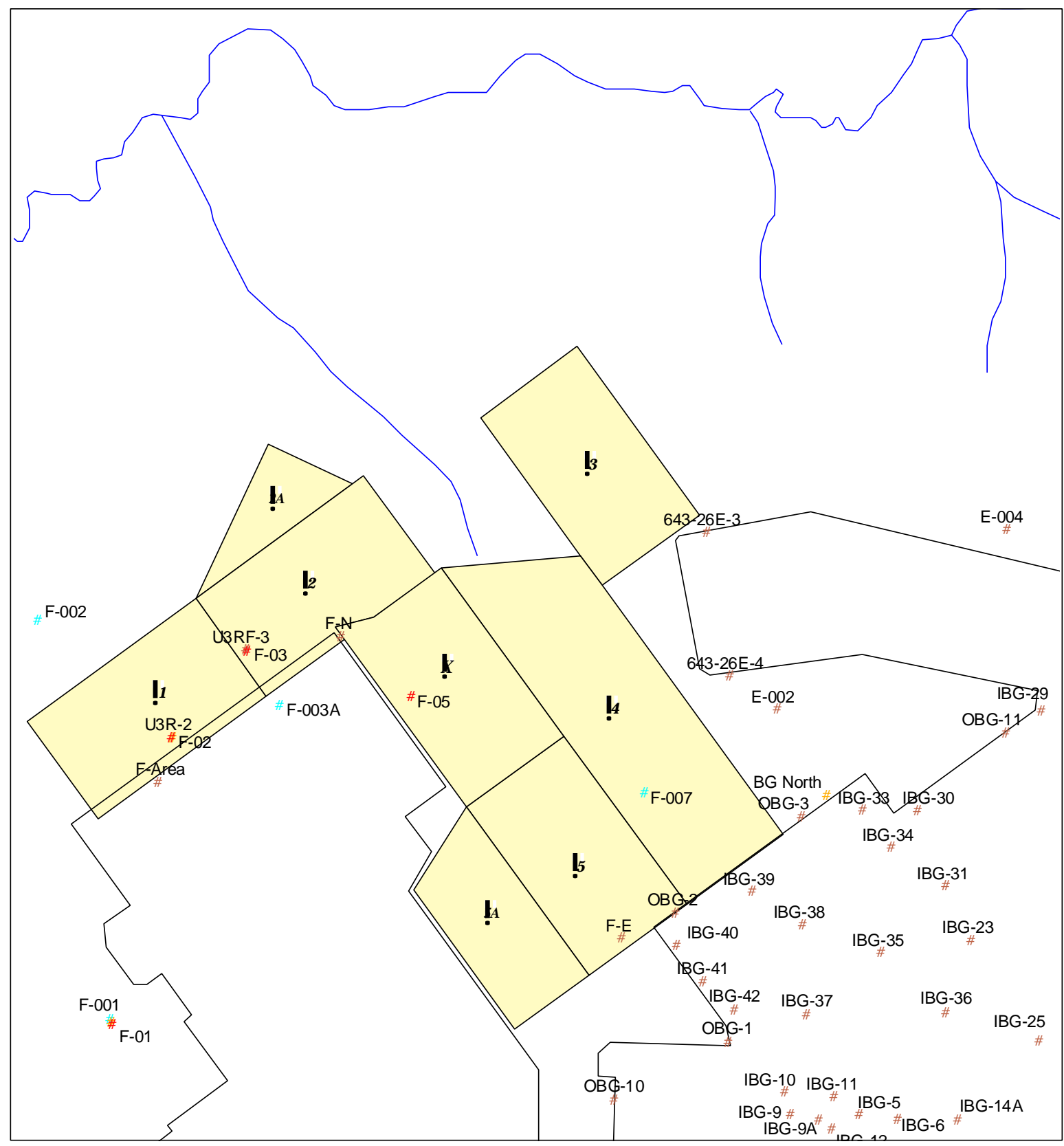

EMS Sampling Locations

\# Current

NPDES Locations

\# Current

\# Current
\# Past

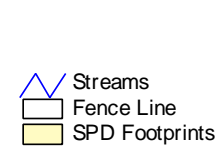

2 


\section{Figure 5}

\section{Groundwater Tritium Plumes}
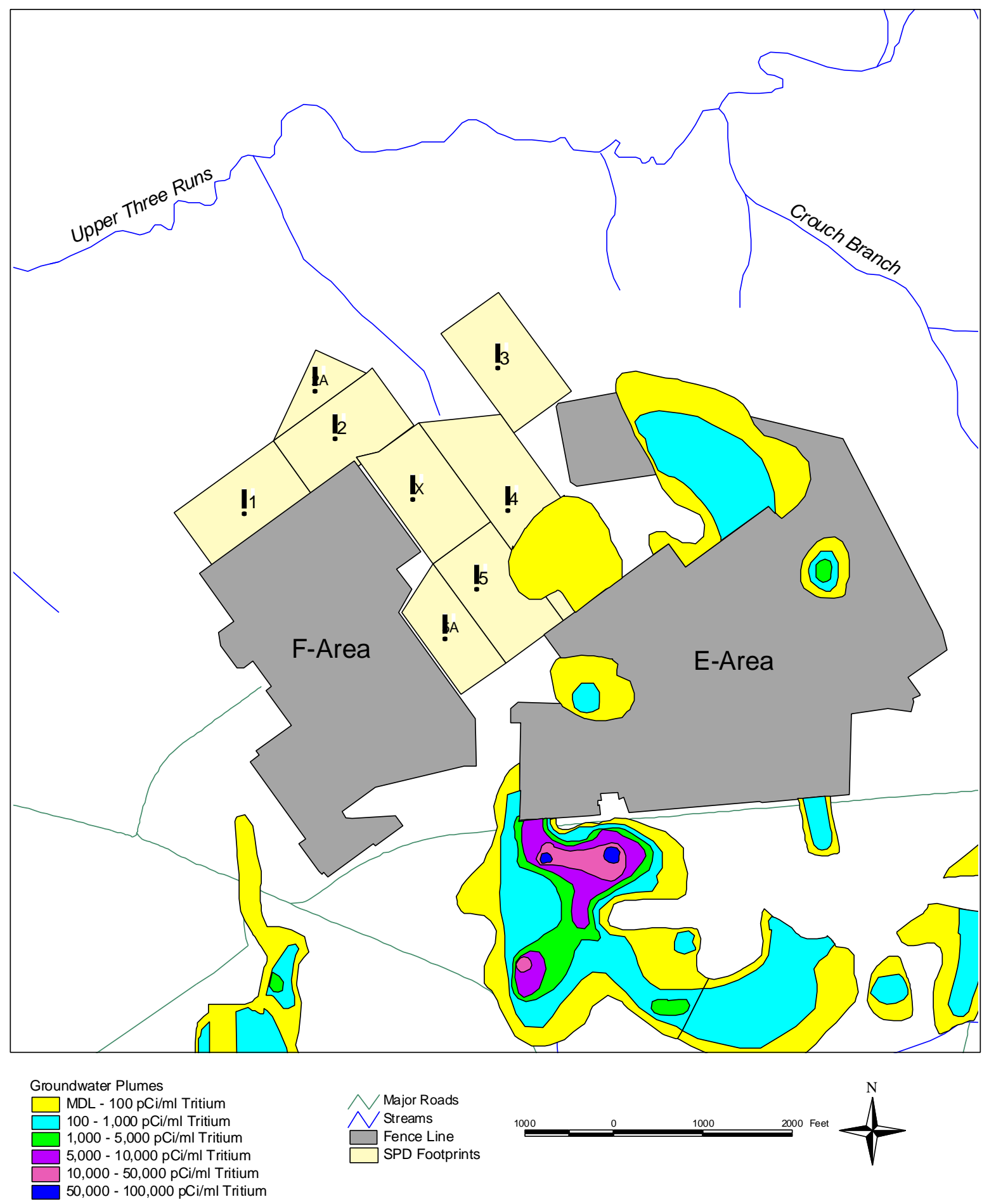
Figure 6

Comparison of Airborne Gross Alpha

Concentrations at All Locations

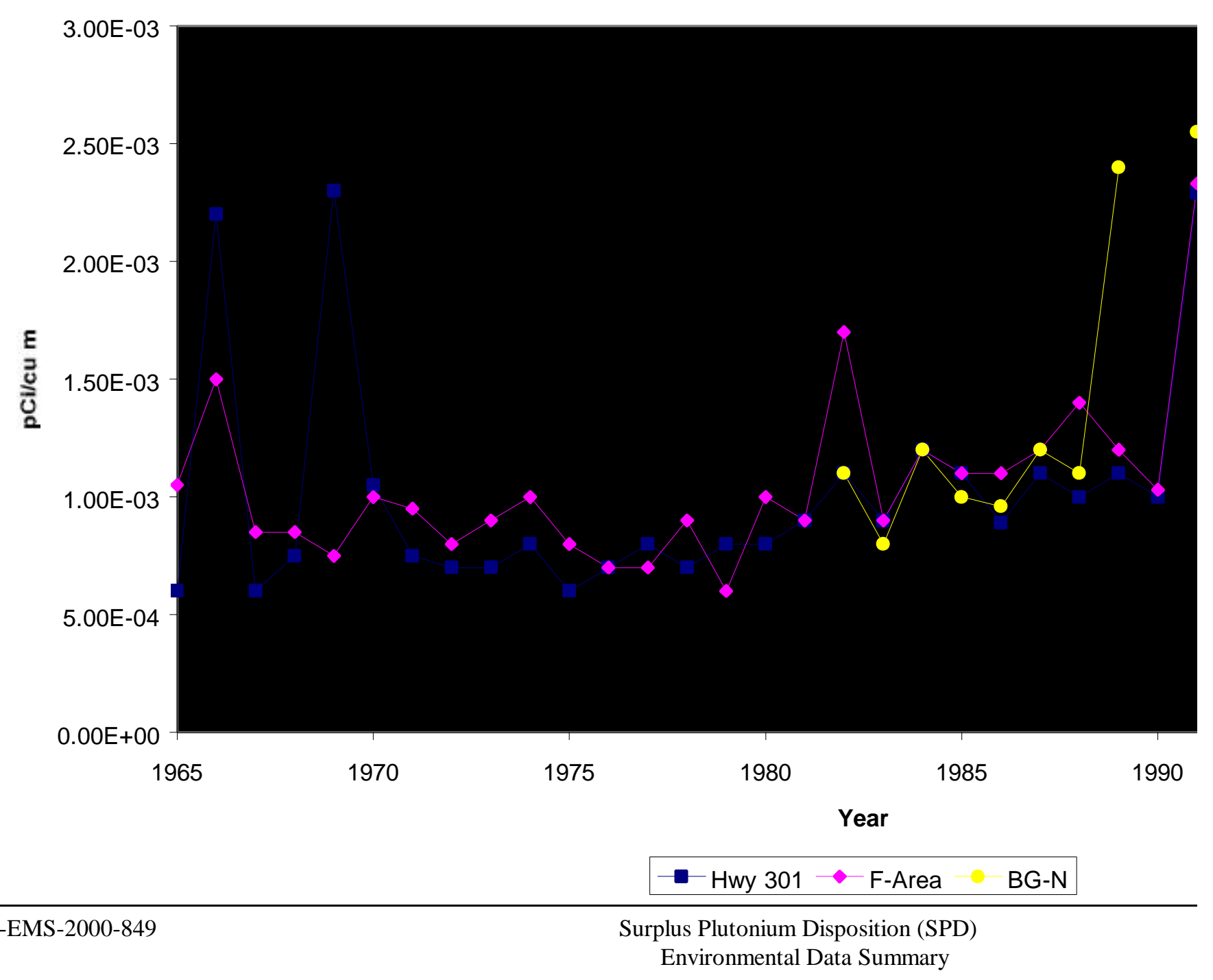


Figure 7

Comparison of Airborne Gross Beta

Concentrations at All Locations

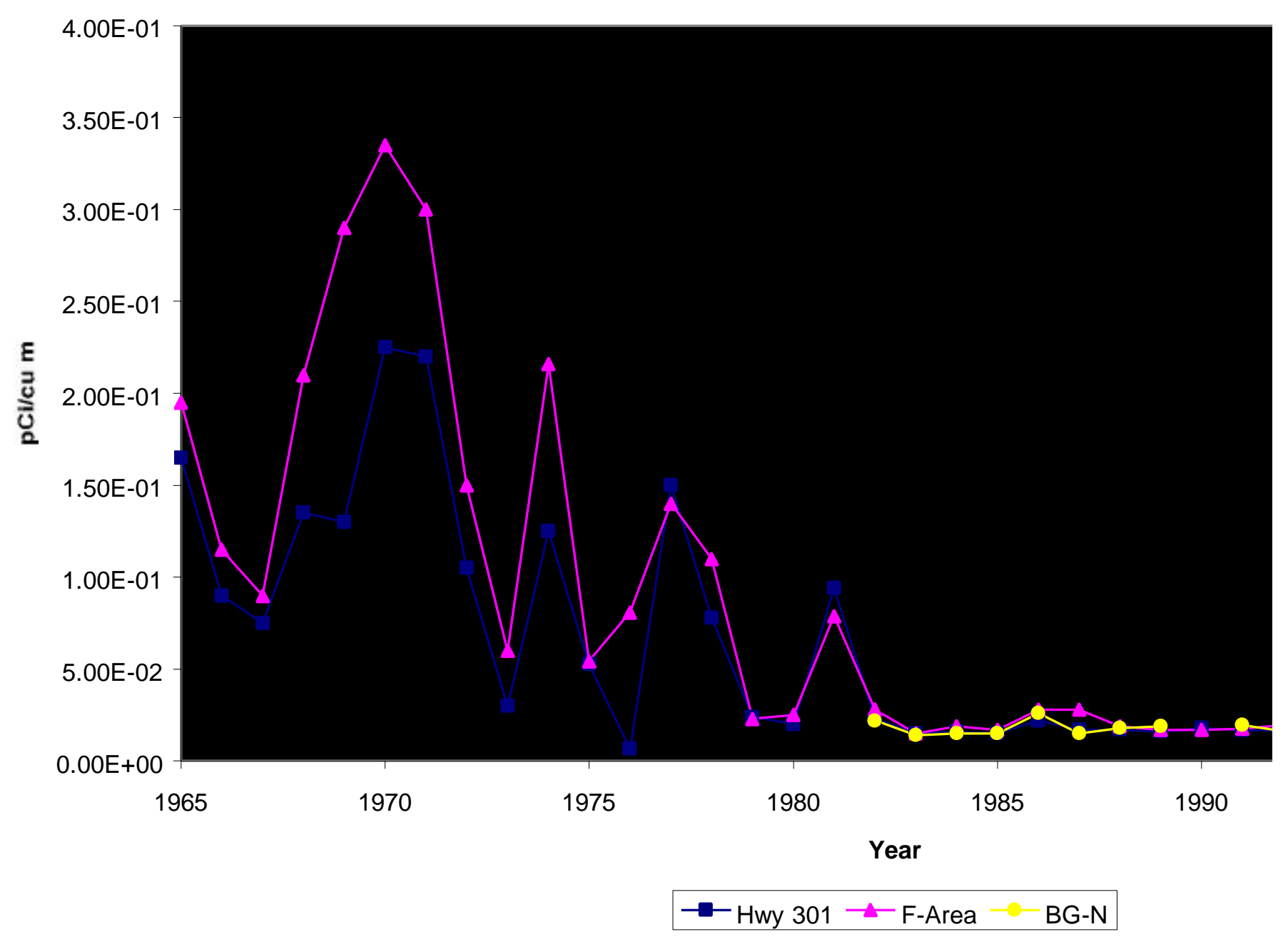

ESH-EMS-2000-849

Surplus Plutonium Disposition (SPD)

Environmental Data Summary 
Figure 8

Comparison of Tritium-in-Air

Concentrations at All Locations

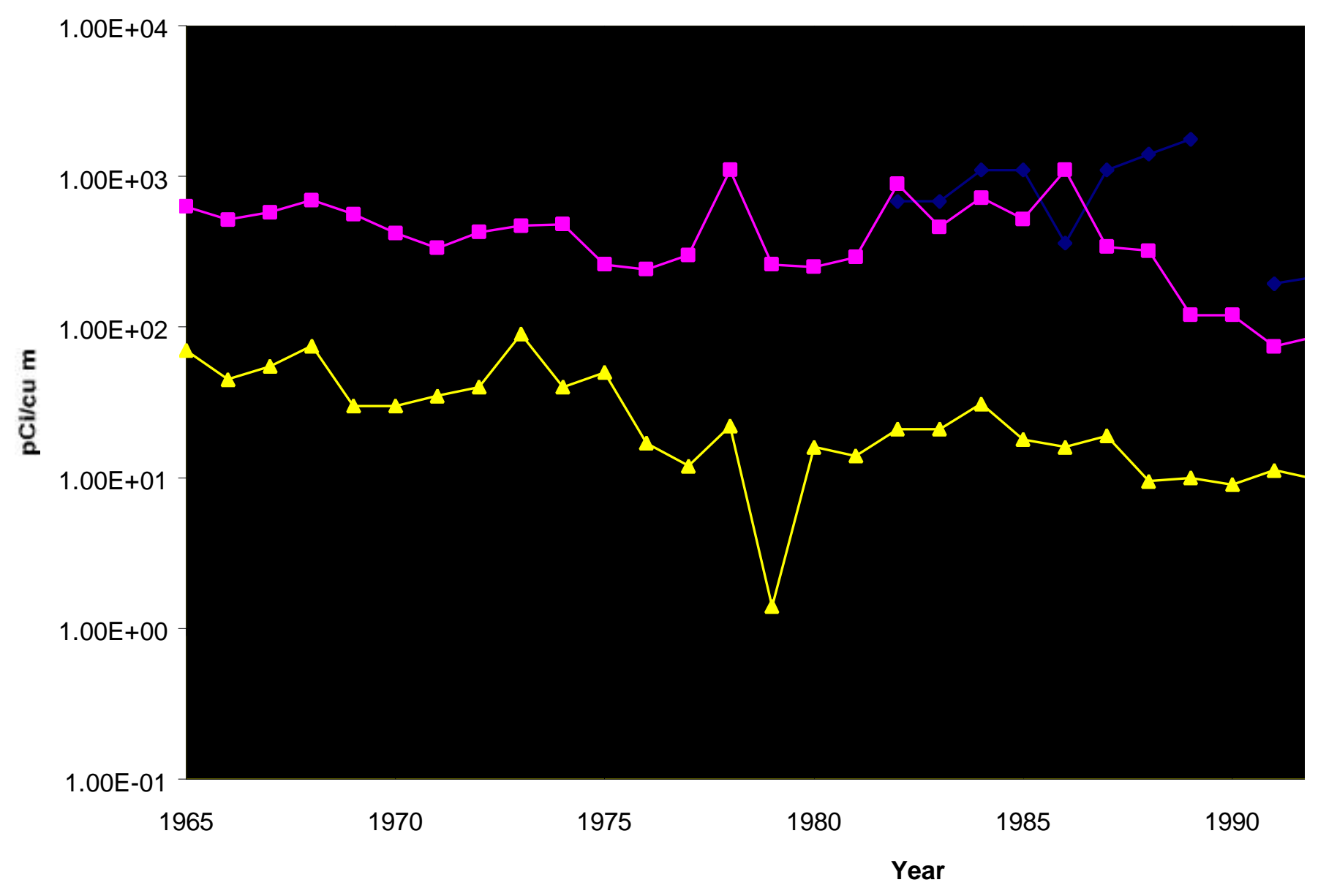

$\rightarrow-$ Burial Ground North - F-Area - Hwy 301 
Figure 9

Gross Alpha and Gross Beta Concentrations at F-Area

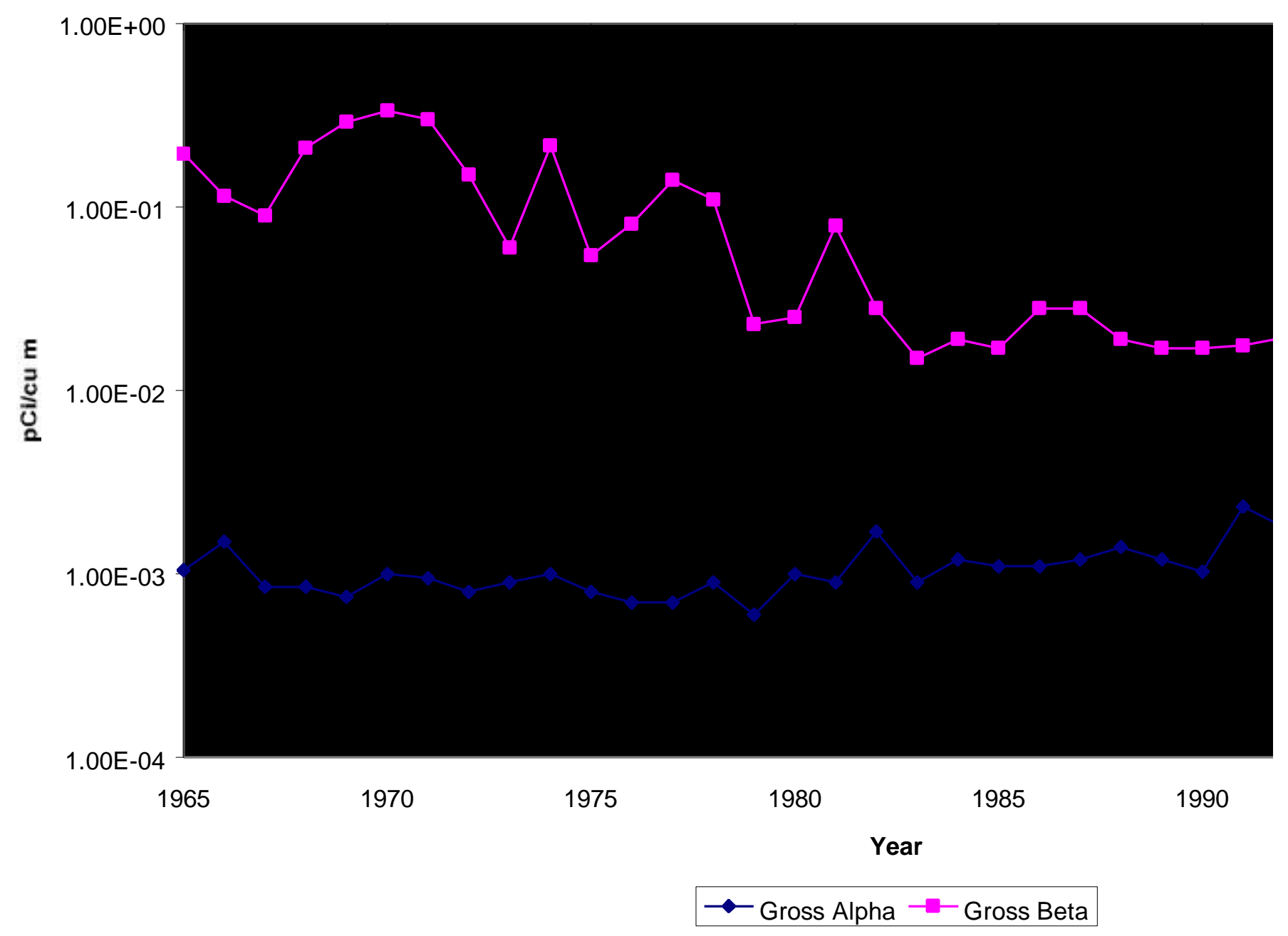


Figure 10

Gross Alpha and Gross Beta Concentrations at Burial Ground North

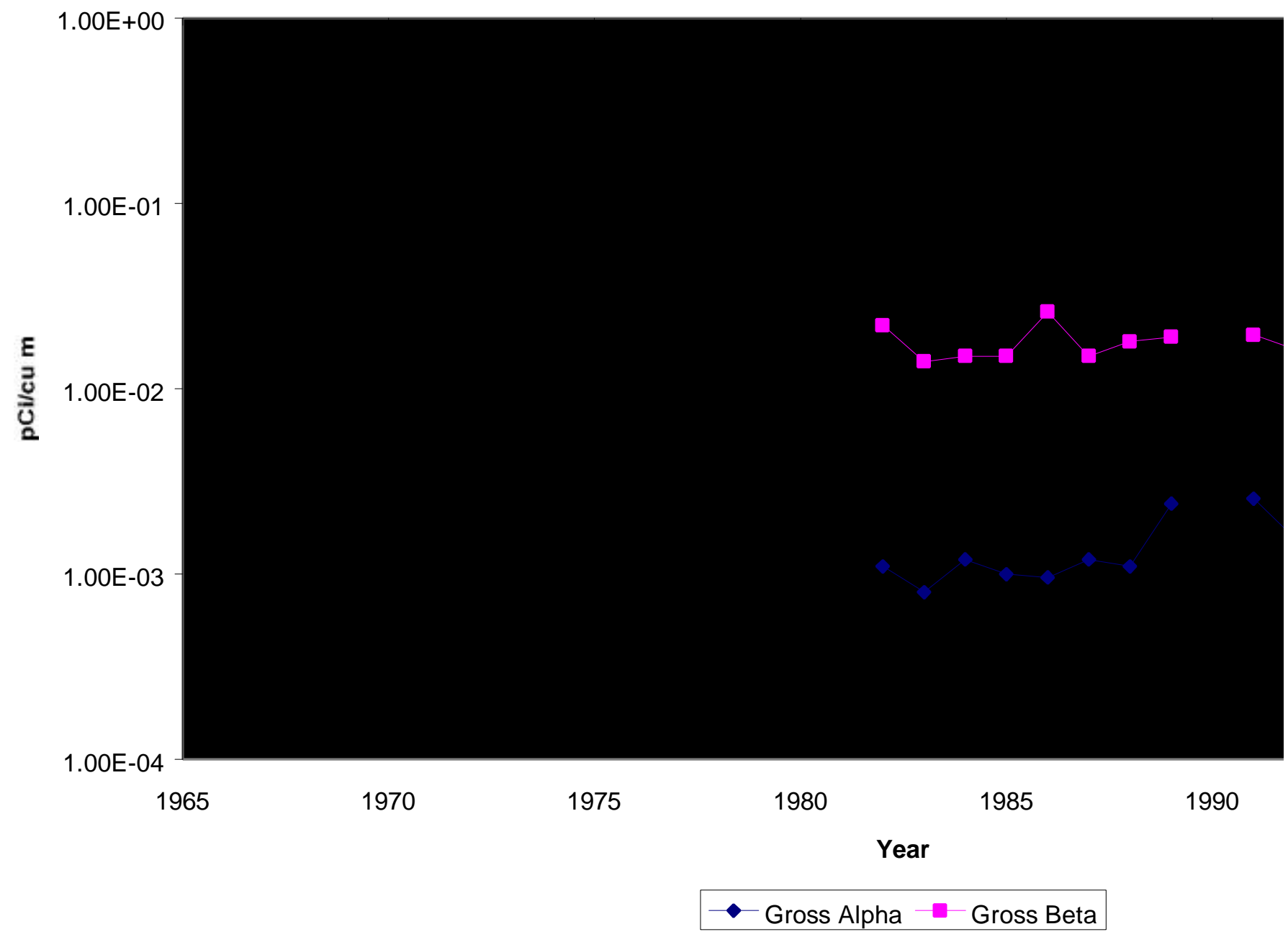


Figure 11

Gross Alpha and Gross Beta Concentrations

at U.S. Highway 301

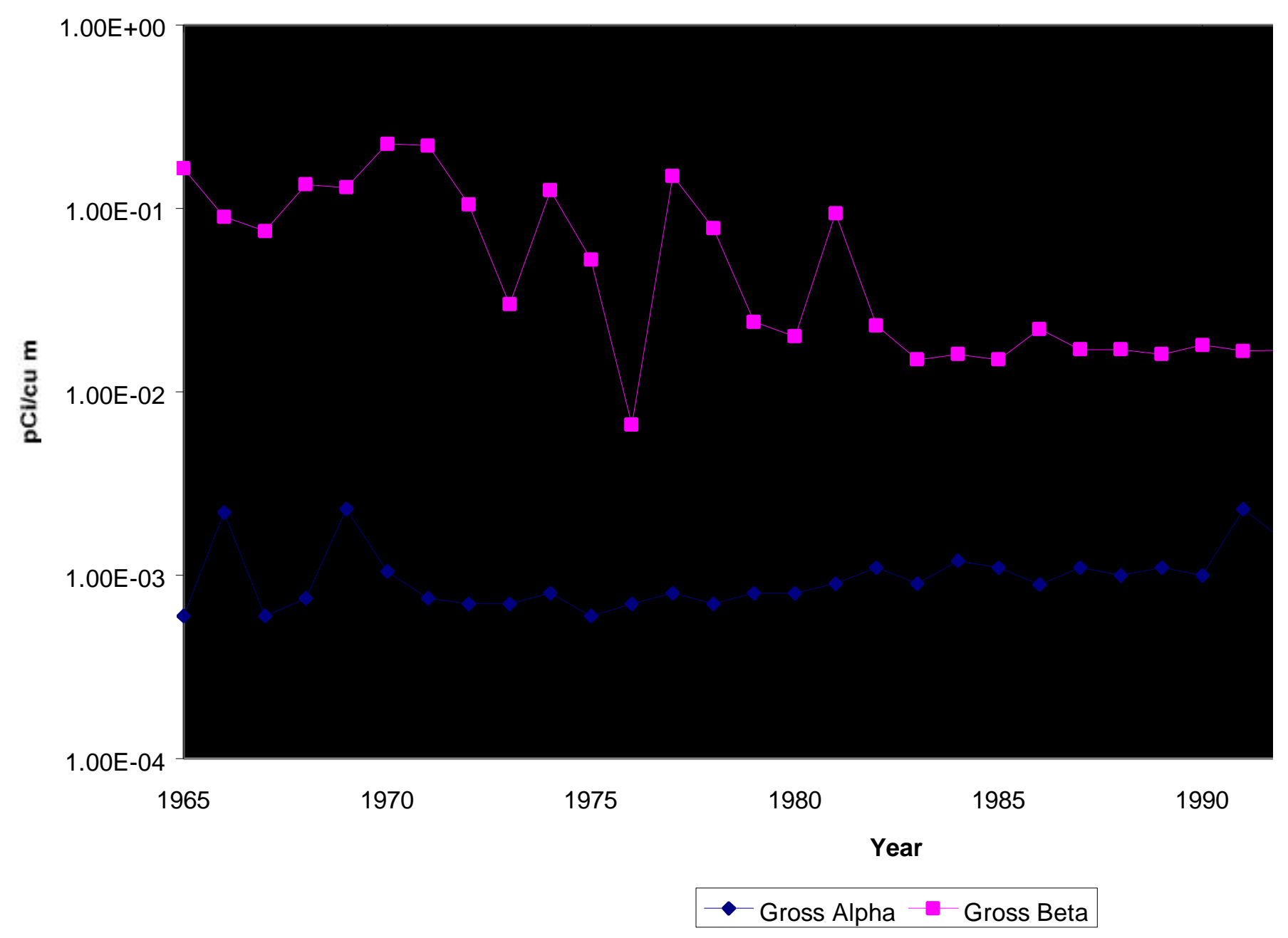


Figure 12

F-Area Filter Paper Co-60 (Weekly Sample)

Baseline Data Plots for Environmental Ai

SDN $=60:$ Location $=$ F-Area $:$ Nuclide $=$ Co- 60

1.65E-02

1.54E-02 -

1.43E-02 -

1.32E-02 -

$\sum$

¿ 1.21E-02 -

드

드 1.10E-02 -

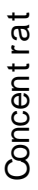

$9.89 \mathrm{E}-03-$

8.79E-03-

7.69E-03-

$6.59 \mathrm{E}-03-$

5.49E-03-

01JAN95

01JAN96

01JAN97

01JAN98

01JAN99

Collection Date 
Figure 13

F-Area Filter Paper Cs-137 (Weekly Sample)

Baseline Data Plots for Environmental $\mathrm{Ai}$

SDN $=60:$ Location $=$ F-Area $:$ Nuclide $=$ Cs-137

$-7.85 \mathrm{E}-04-\overline{-}-33 \mathrm{E}-04-$
-

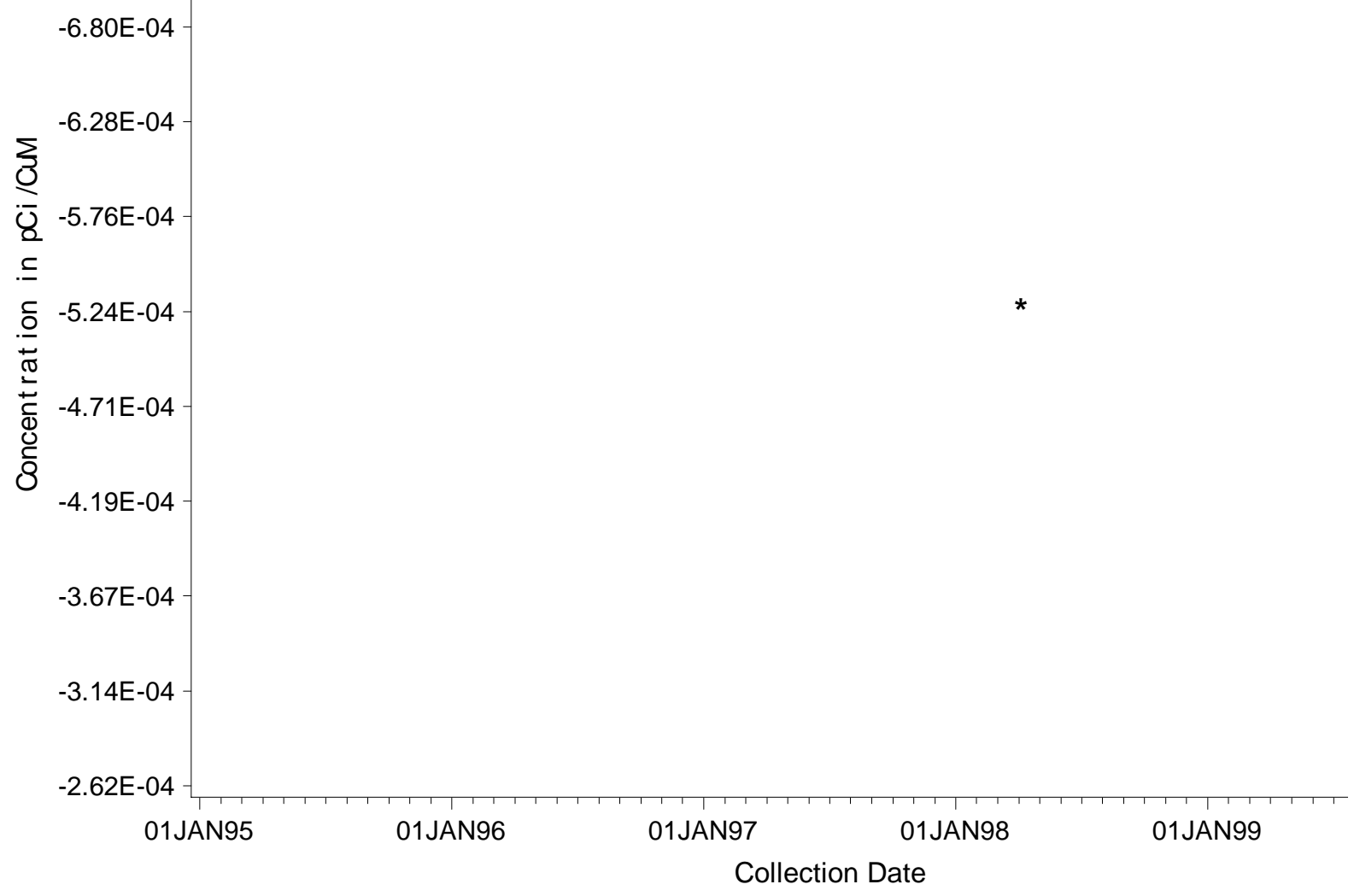


Figure 14

F-Area Filter Paper Gross Beta (Weekly Sample)

Baseline Data Plots for Environmental $\mathrm{Ai}$

SDN $=60:$ Location $=$ F-Area $:$ Nuclide $=$ Gross B

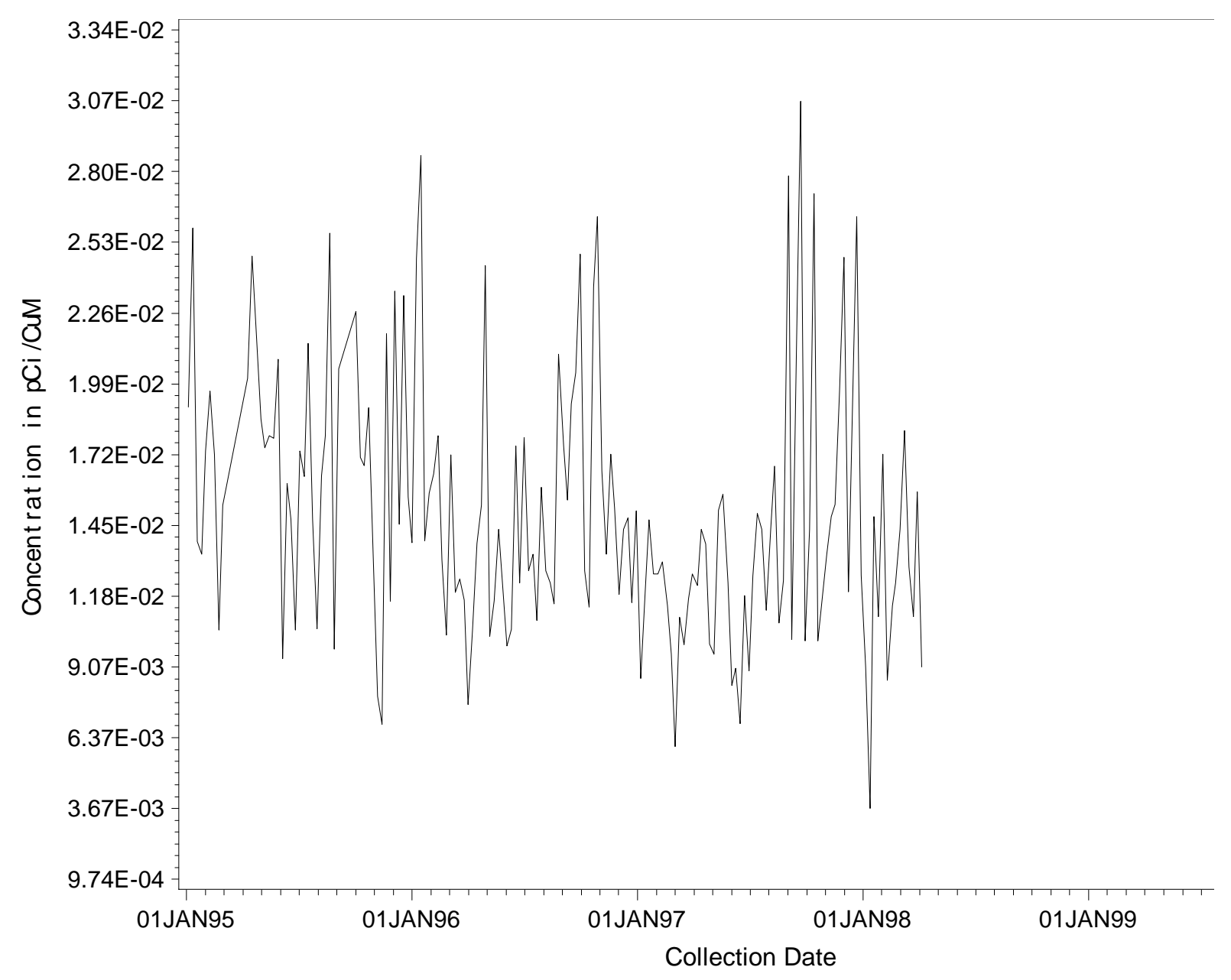


Figure 15

F-Area Filter Paper Gross Alpha (Weekly Sample)

Baseline Data Plots for Environmental $\mathrm{Ai}$

SDN $=60:$ Location $=$ F-Area $:$ Nuclide $=$ Gross $A$

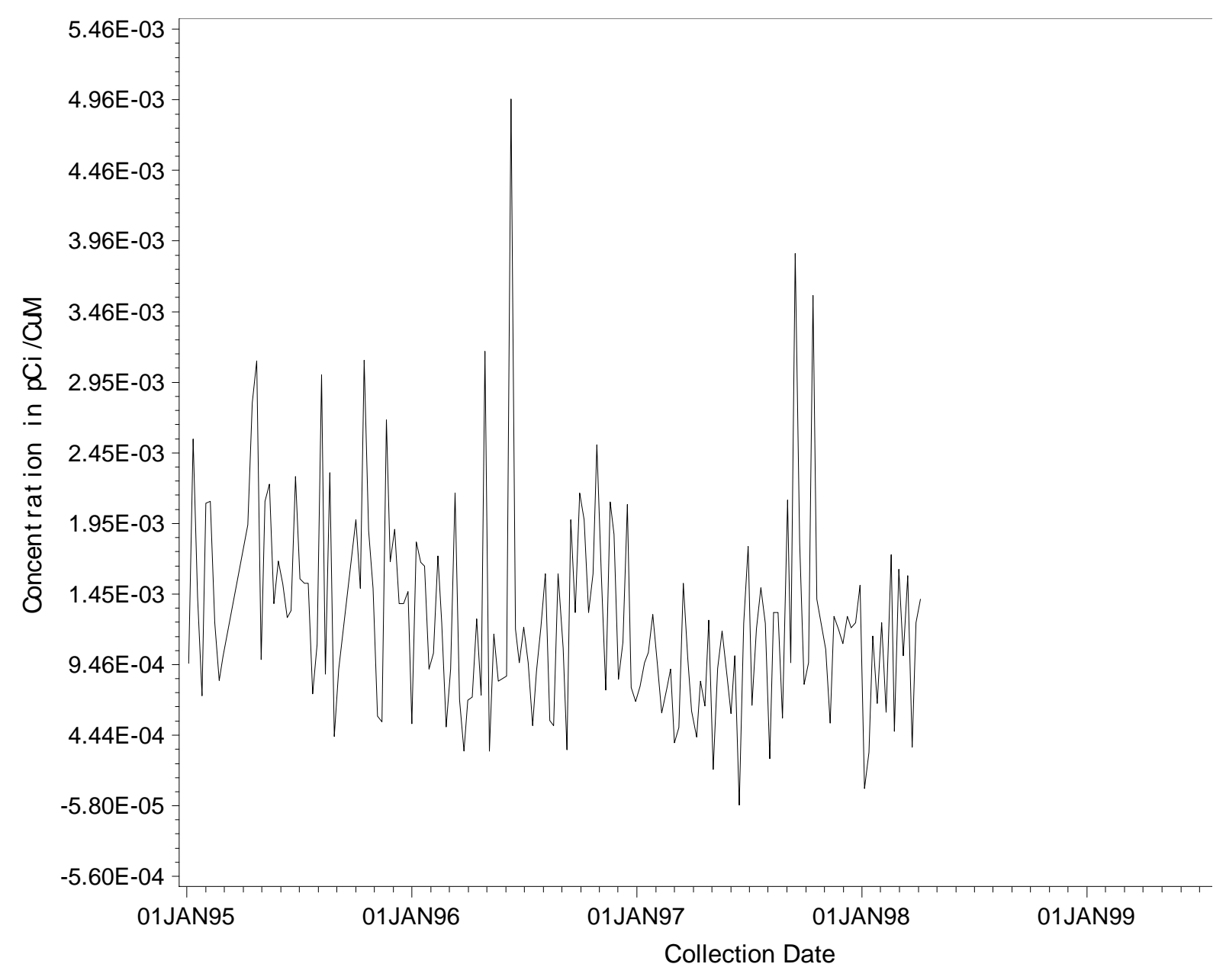

ESH-EMS-2000-849

Surplus Plutonium Disposition (SPD)

Environmental Data Summary 
Figure 16

F-Area Filter Paper Co-60 (Monthly Composite)

Baseline Data Plots for Environmental $\mathrm{Ai}$

SDN $=10066:$ Location $=$ F-Area $:$ Nuclide $=$ Co-60

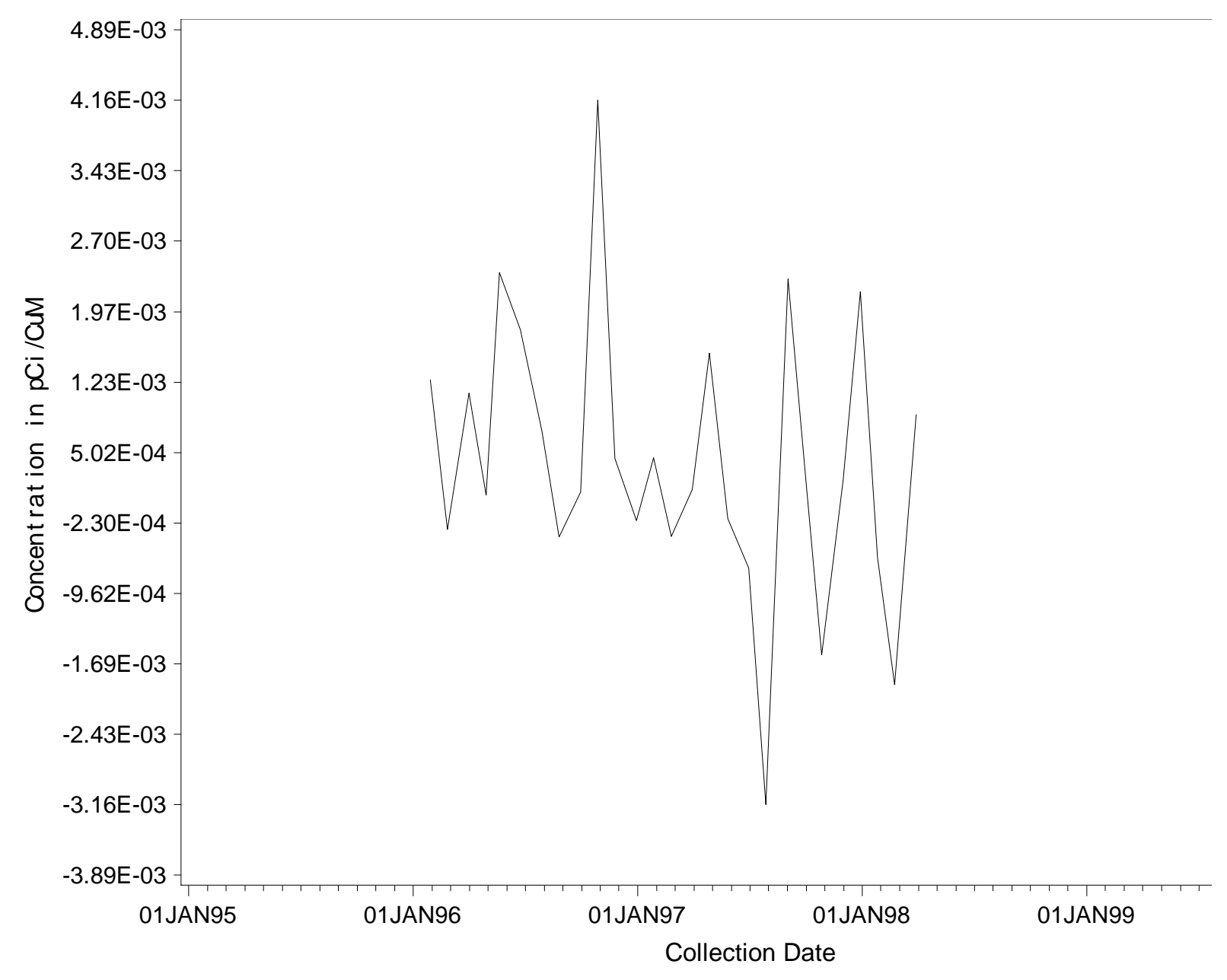

ESH-EMS-2000-849

Surplus Plutonium Disposition (SPD)

Environmental Data Summary 
Figure 17

F-Area Filter Paper Cs-137 (Monthly Composite)

Baseline Data Plots for Environmental $\mathrm{Ai}$

SDN $=10066:$ Location = F-Area $:$ Nuclide $=$ Cs-137

\subsection{E-03}

$1.55 \mathrm{E}-03-$

1.17E-03-

7.94E-04 -

$\sum_{0} 4.18 \mathrm{E}-04-$

ষ্ 4.20E-05-

$\subseteq$

ธ -3.34E-04 -

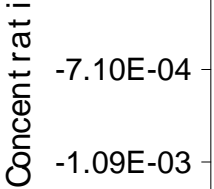

$-1.46 \mathrm{E}-03-$

$-1.84 \mathrm{E}-03-$

$-2.21 \mathrm{E}-03-$
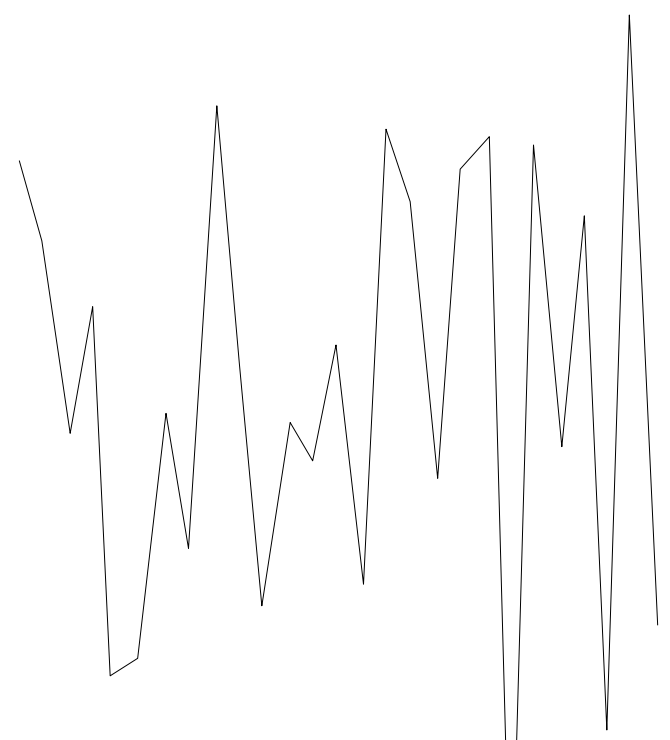

$-2.59 \mathrm{E}-03-$

01JAN95

01JAN96

01JAN98

01JAN99

Collection Date 
Figure 18

F-Area Filter Paper Pu-238 (Monthly Composite)

Baseline Data Plots for Environmental $\mathrm{Ai}$

SDN $=10066:$ Location $=$ F-Area $:$ Nuclide $=$ Pu-238

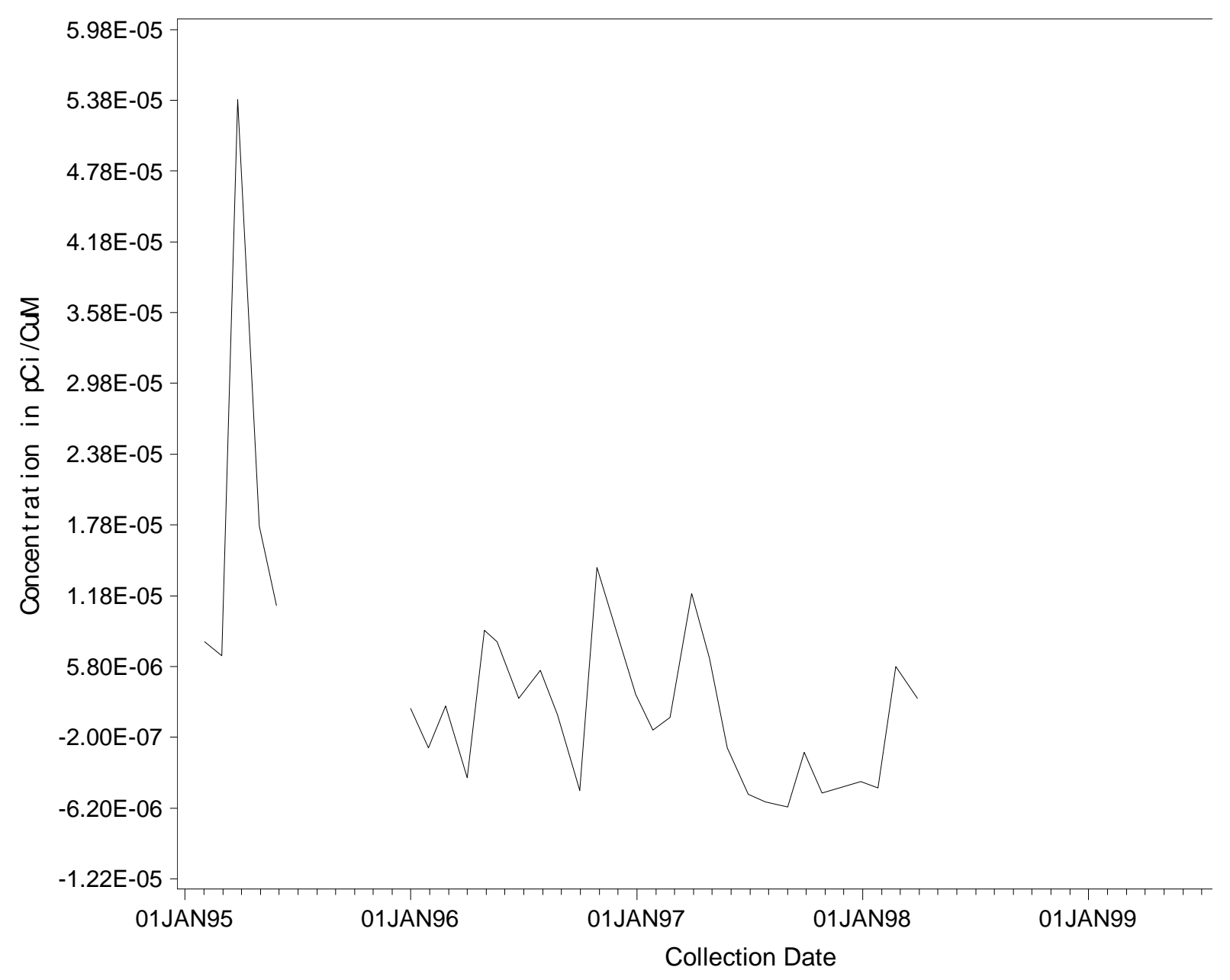


Figure 19

F-Area Filter Paper Pu-239 (Monthly Composite)

Baseline Data Plots for Environmental $\mathrm{Ai}$

SDN $=10066:$ Location $=$ F-Area $:$ Nuclide $=$ Pu-239

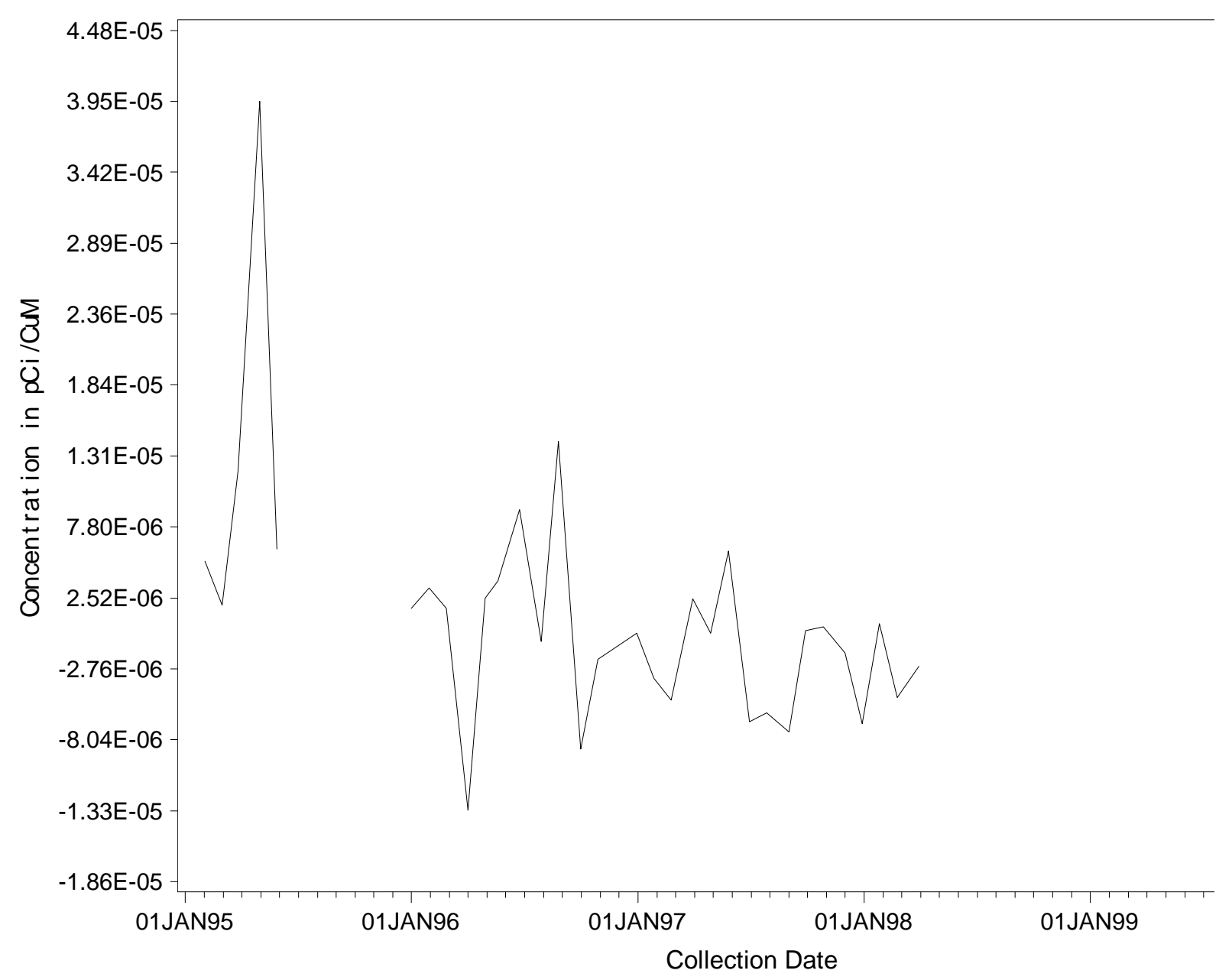


Figure 20

\section{F-Area Filter Paper Sr-89,90 (Monthly Composite)}

Baseline Data Plots for Environmental $\mathrm{Ai}$

SDN $=10066:$ Location $=$ F-Area $:$ Nuclide $=$ Sr-89,90

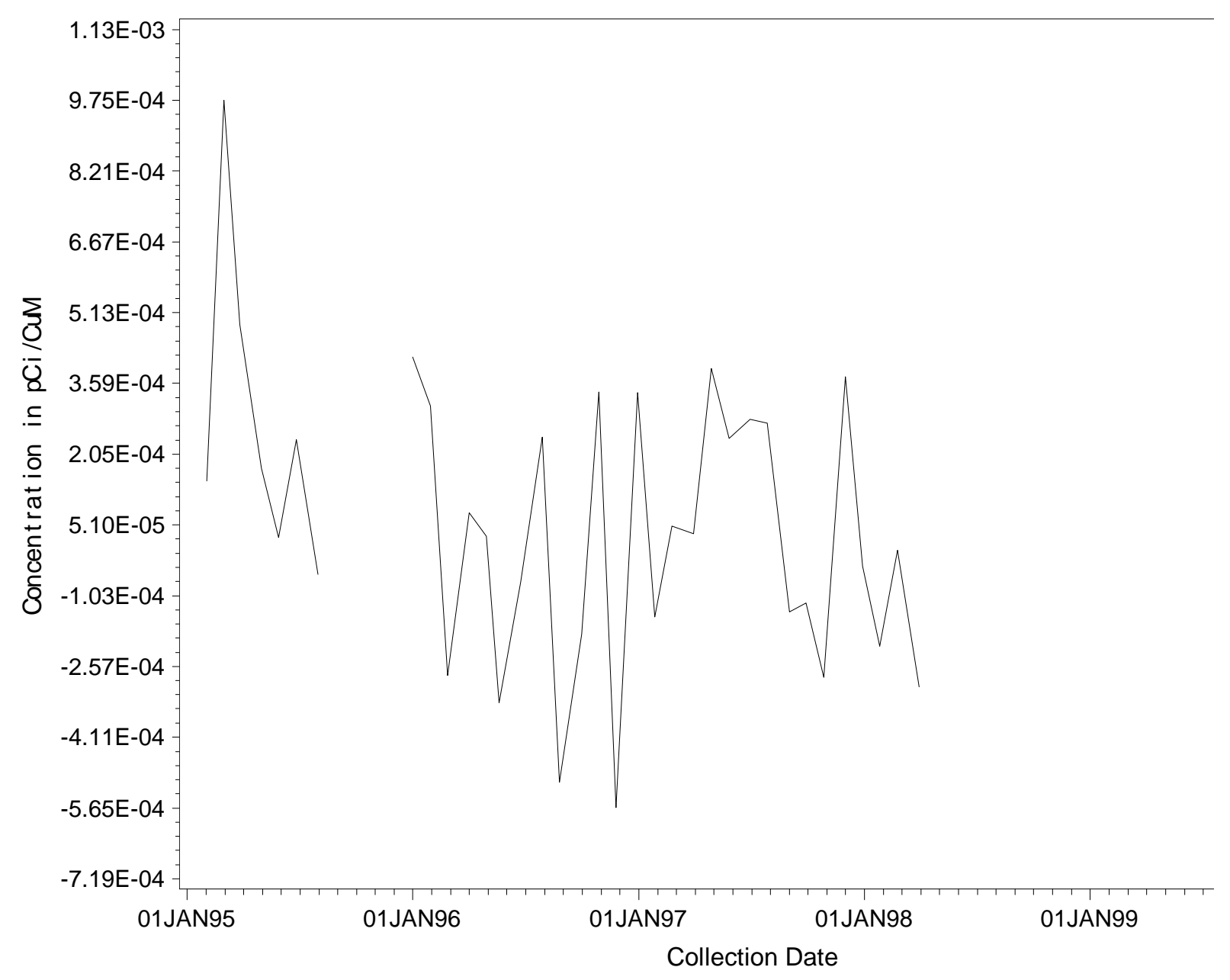


Figure 21

F-Area Charcoal Canister Co-60 (Weekly Sample)

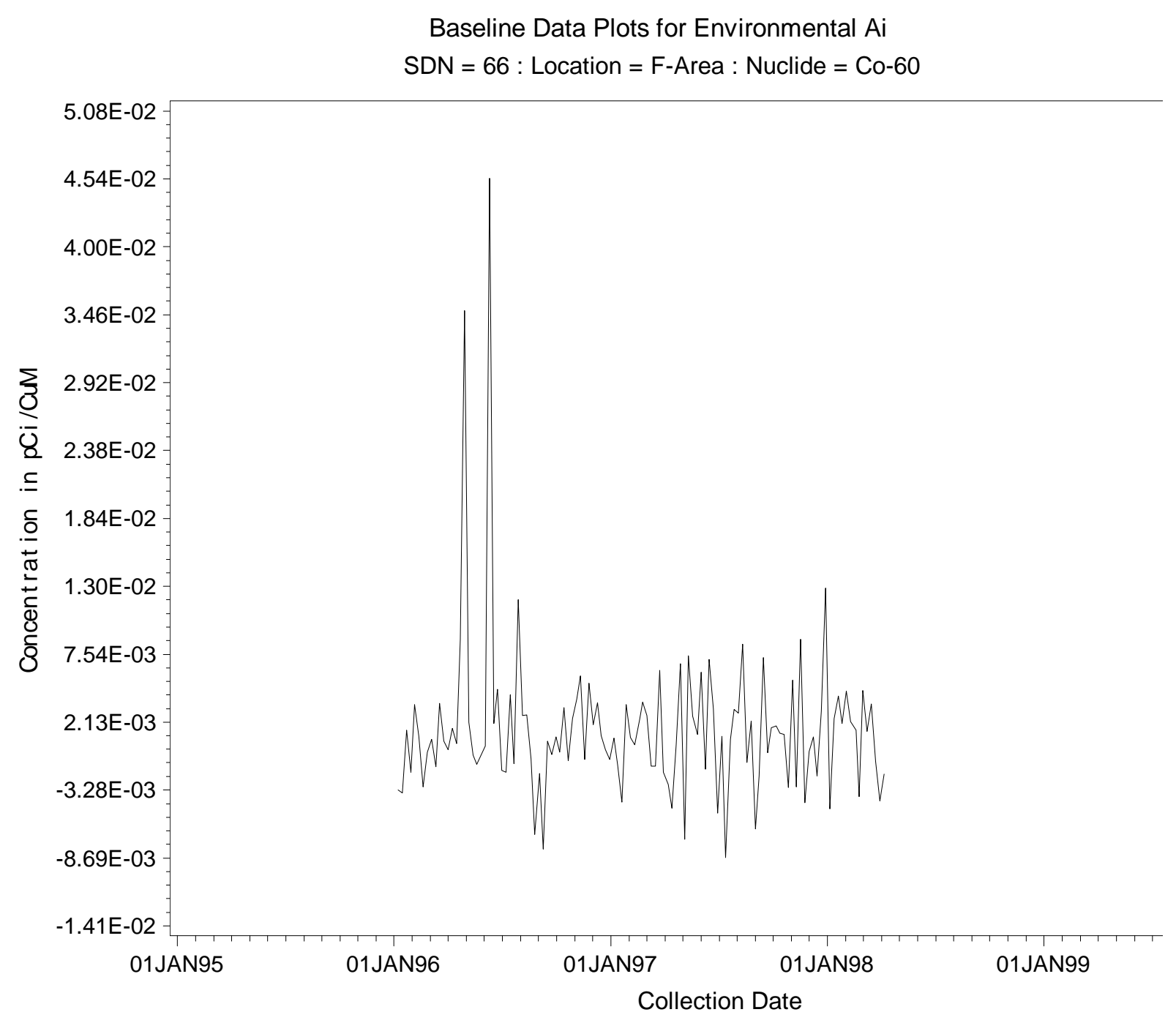


Figure 22

F-Area Charcoal Canister Cs-137 (Weekly Sample)

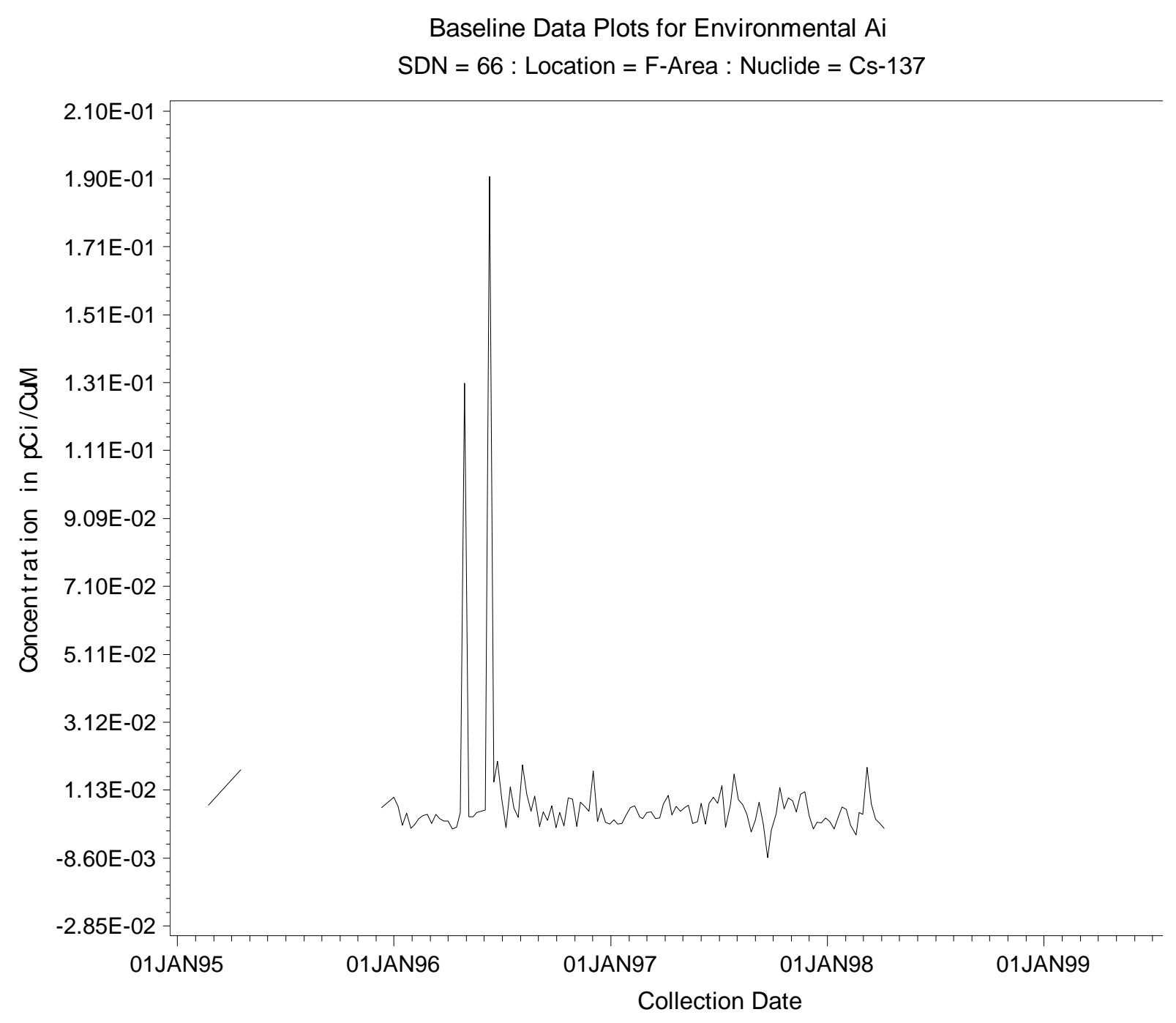


Figure 23

\section{F-Area Silica Gel H-3 (Biweekly Sample)}

Baseline Data Plots for Environmental Ai

$\mathrm{SDN}=80$ : Location $=$ F-Area $:$ Nuclide $=\mathrm{H}-3$

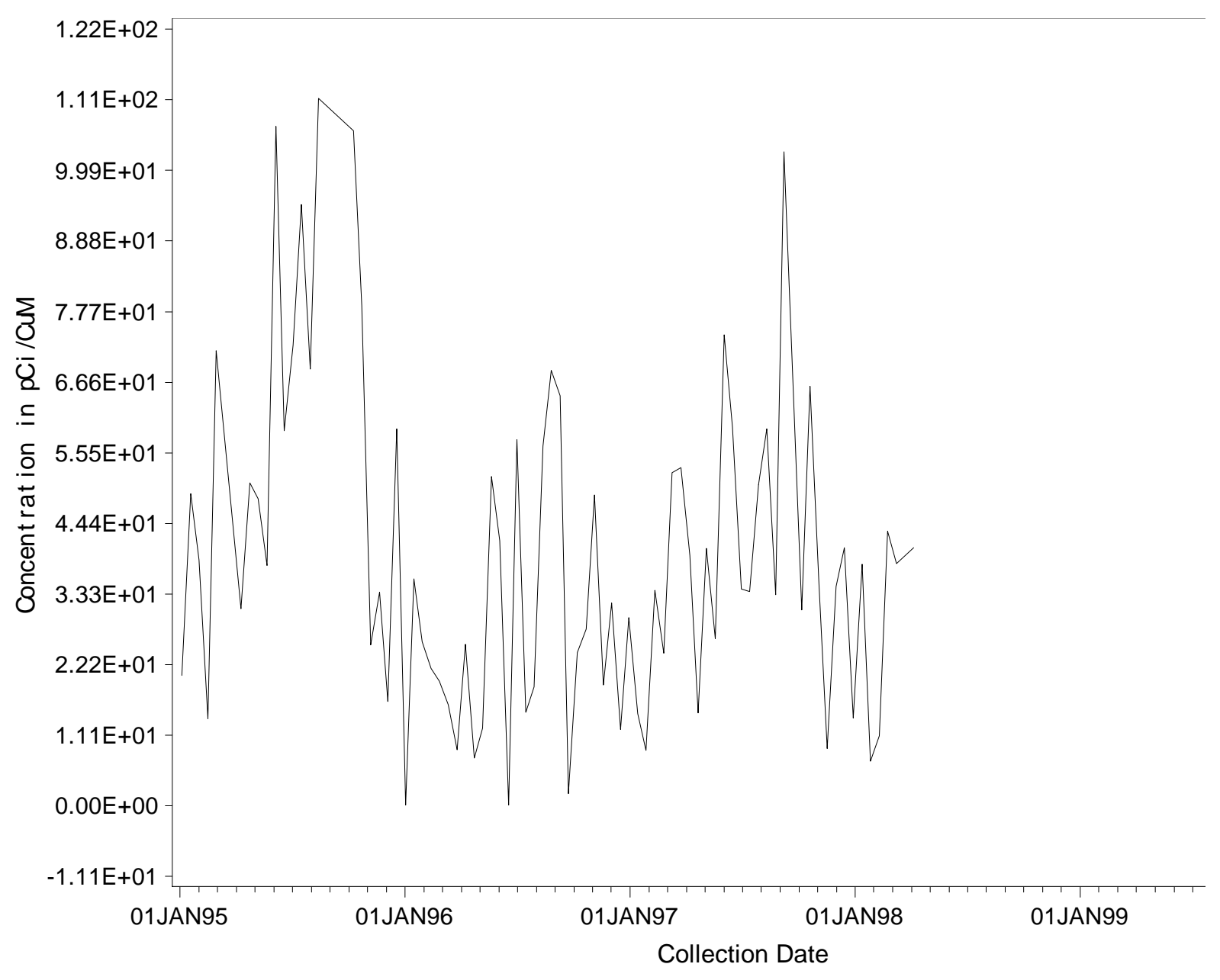


Figure 24

F-Area Rainwater H-3 (Biweekly Sample)

Baseline Data Plots for Rainwater

SDN $=1483:$ Location $=$ F-Area $:$ Nuclide $=\mathrm{H}-3$

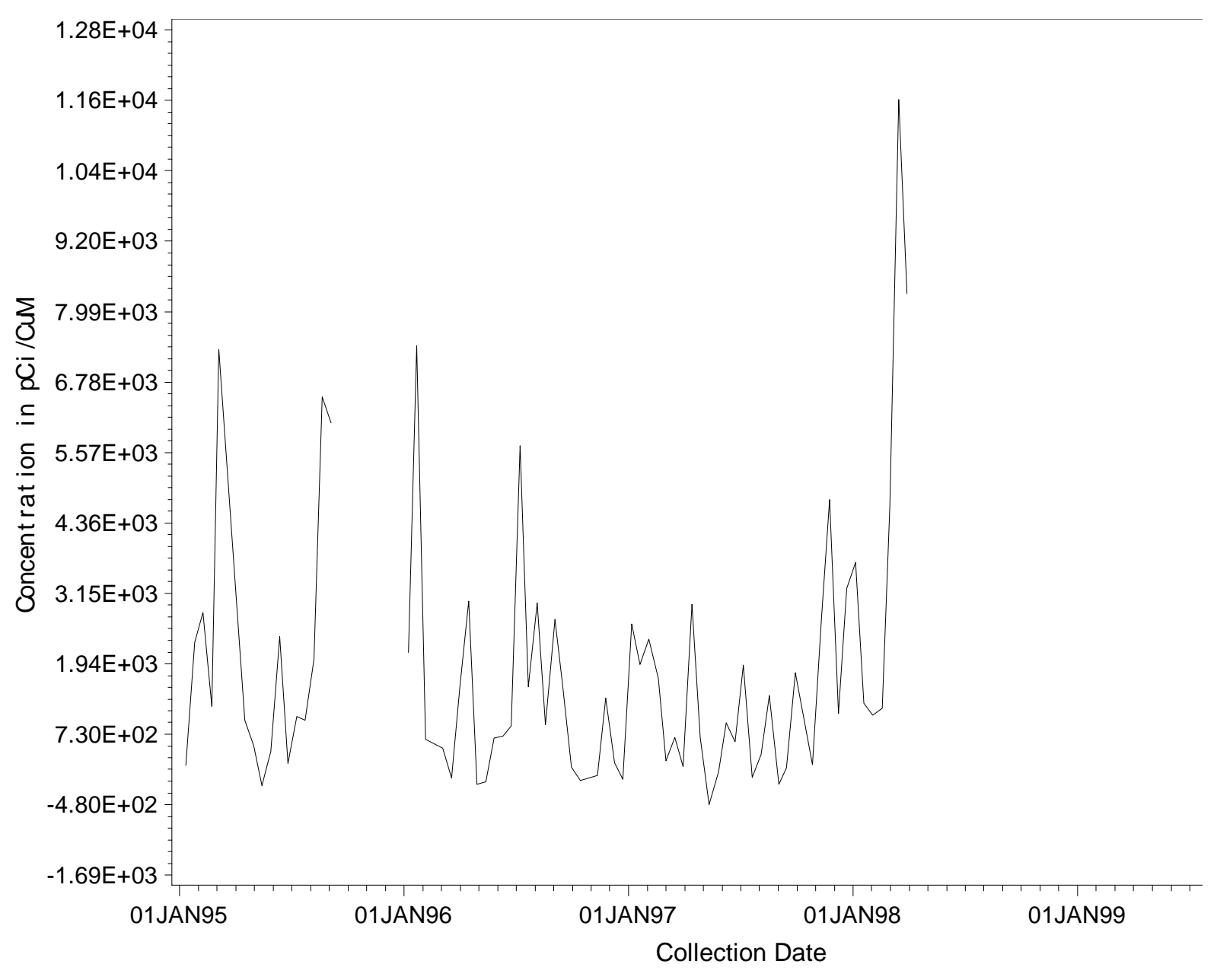

ESH-EMS-2000-849

Surplus Plutonium Disposition (SPD)

Environmental Data Summary 
Figure 25

Burial Ground North Filter Paper Co-60 (Weekly Sample)

\author{
Baseline Data Plots for Environmental Ai \\ SDN $=64:$ Location $=$ Burial Ground North $:$ Nuclide $=$ Co-60
}

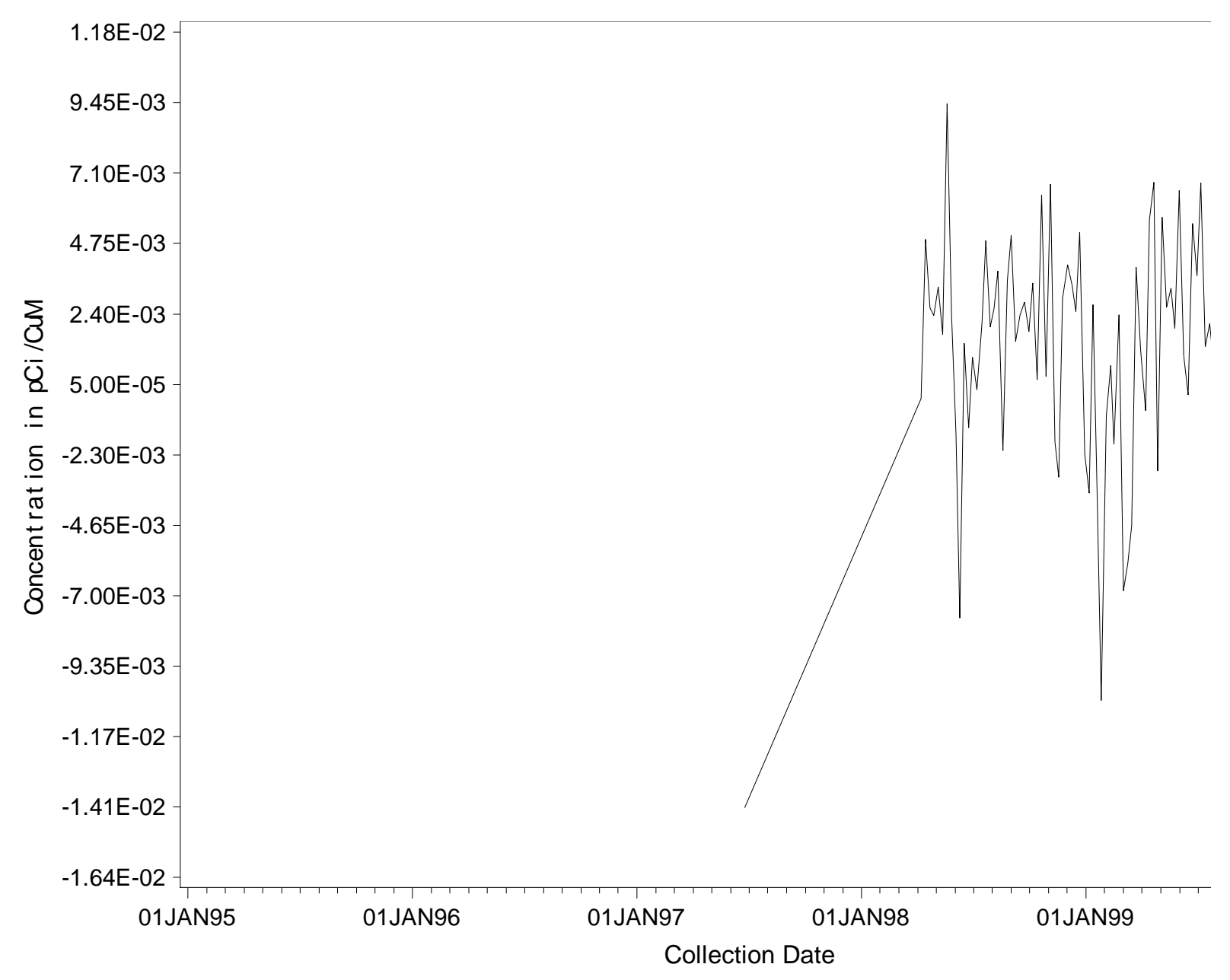


Figure 26

\section{Burial Ground North Filter Paper Cs-137 (Weekly Sample)}

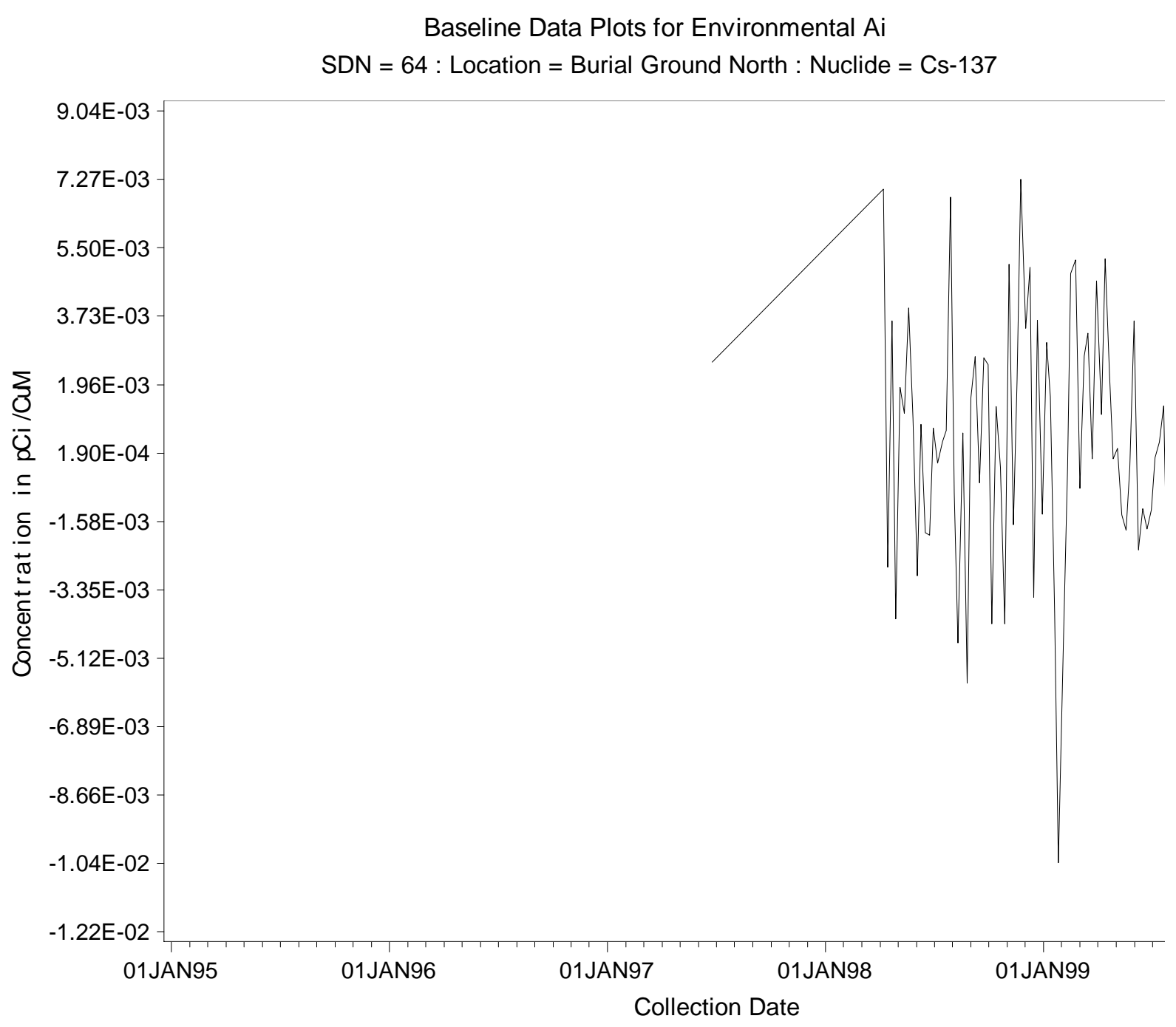


Figure 27

Burial Ground North Filter Paper U-234 (Annual Sample)

\author{
Baseline Data Plots for Environmental $\mathrm{Ai}$ \\ SDN $=64:$ Location $=$ Burial Ground North $:$ Nuclide $=U-234$
}

2.39E-06-

2.23E-06 -

2.07E-06 -

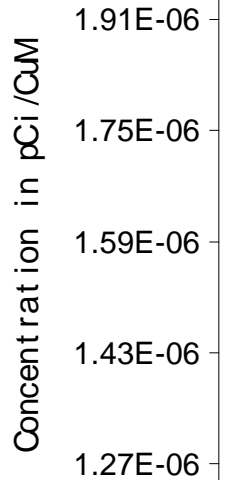

$1.11 \mathrm{E}-06$

9.54E-07 -

7.95E-07 -

01JAN95

01JAN96

01JAN97

01JAN98

01JAN99

Collection Date 
Figure 28

Burial Ground North Filter Paper U-235 (Annual Sample)

\author{
Baseline Data Plots for Environmental Ai \\ SDN $=64:$ Location $=$ Burial Ground North $:$ Nuclide $=$ U-235
}

$1.08 \mathrm{E}-05$

$1.01 \mathrm{E}-05-$

9.36E-06-

8.64E-06 -

$\sum$

8. 7.92E-06-

$\subseteq$

드 7.20E-06-

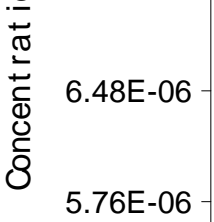

$5.04 \mathrm{E}-06$

4.32E-06 -

3.60E-06 -

01JAN95

01JAN96

01JAN97

01JAN98

01JAN99

Collection Date 
Figure 29

Burial Ground North Filter Paper U-238 (Annual Sample)

\author{
Baseline Data Plots for Environmental $\mathrm{Ai}$ \\ SDN $=64:$ Location $=$ Burial Ground North $:$ Nuclide $=U-238$
}

2.69E-05-

2.51E-05-

2.33E-05-

2.15E-05-

$\sum_{0}$

ष 1.97E-05-

$\subseteq$

드 1.79E-05 -

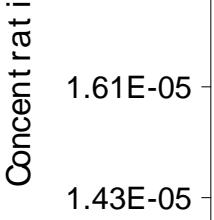

$1.25 \mathrm{E}-05$

$1.08 \mathrm{E}-05$

8.96E-06 -

01JAN95

01JAN96

01JAN97

01JAN98

01JAN99

Collection Date 
Figure 30

\title{
Burial Ground North Filter Paper Pu-238 (Annual Sample)
}

\author{
Baseline Data Plots for Environmental $\mathrm{Ai}$ \\ SDN $=64:$ Location $=$ Burial Ground North $:$ Nuclide $=$ Pu-238
}

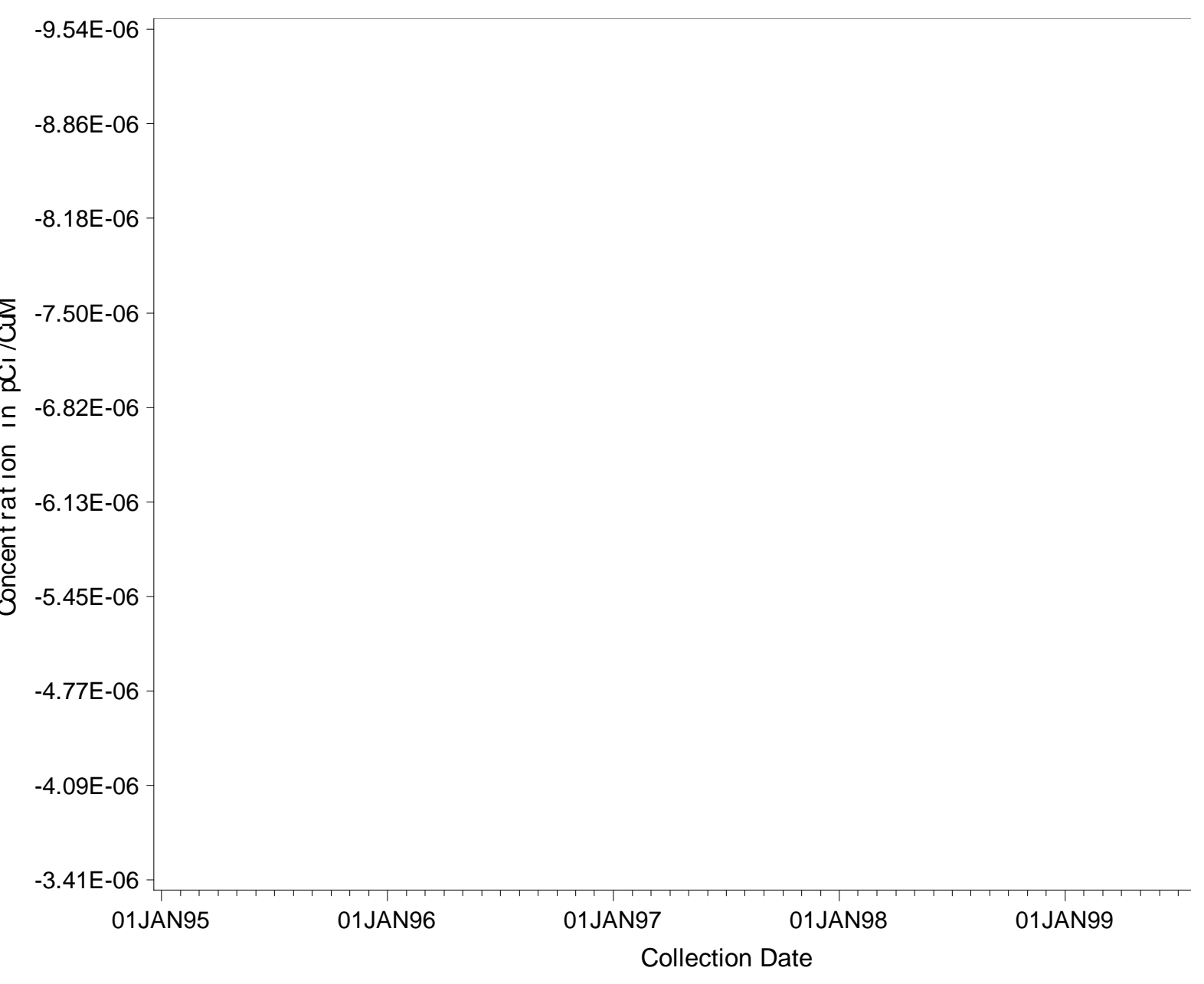


Figure 31

\title{
Burial Ground North Filter Paper Pu-239 (Annual Sample)
}

\author{
Baseline Data Plots for Environmental $\mathrm{Ai}$ \\ SDN $=64:$ Location $=$ Burial Ground North $:$ Nuclide $=$ Pu-239
}

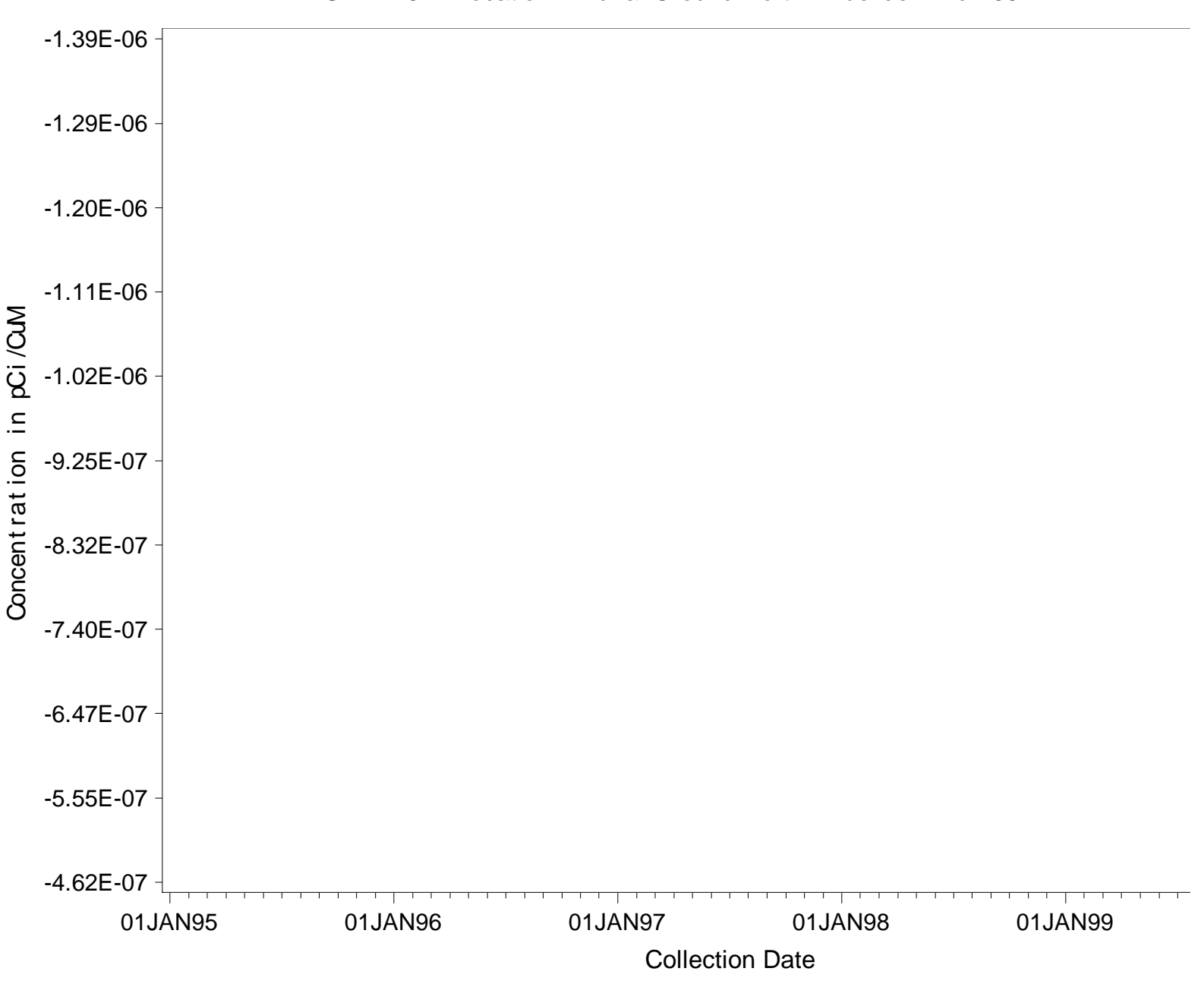


Figure 32

\section{Burial Ground North Filter Paper Am-241 (Annual Sample)}

Baseline Data Plots for Environmental $\mathrm{Ai}$

SDN $=64:$ Location $=$ Burial Ground North $:$ Nuclide $=$ Am-241

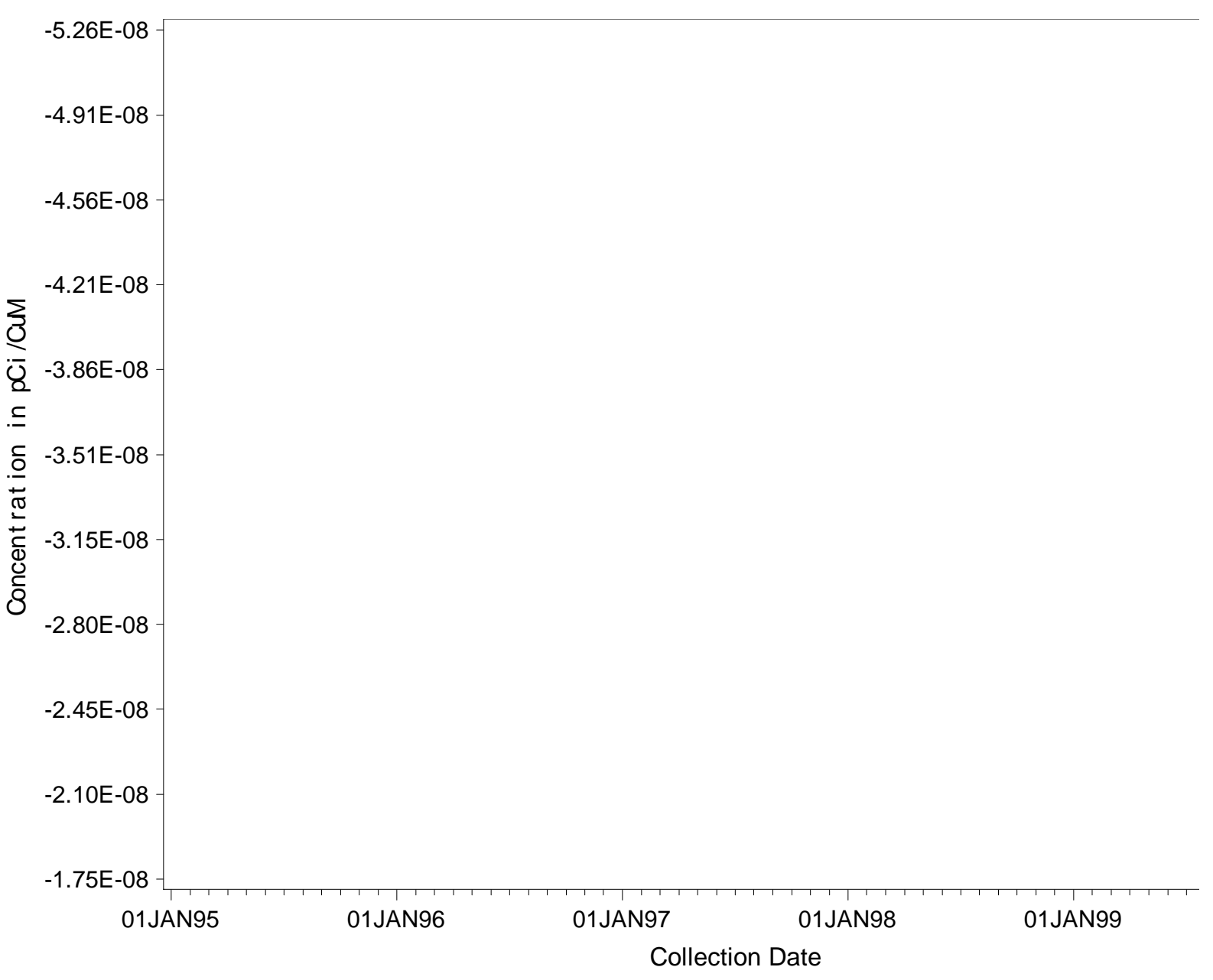


Figure 33

\title{
Burial Ground North Filter Paper Cm-244 (Annual Sample)
}

\author{
Baseline Data Plots for Environmental $\mathrm{Ai}$ \\ SDN $=64:$ Location $=$ Burial Ground North $:$ Nuclide $=\mathrm{Cm}-244$
}

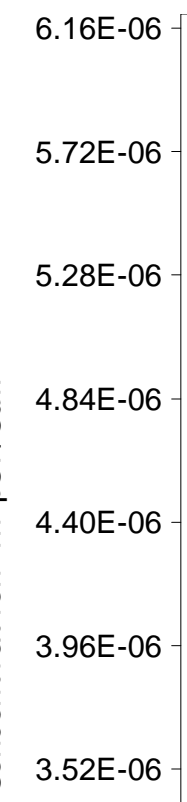

3.08E-06 -

2.64E-06-

2.20E-06 -

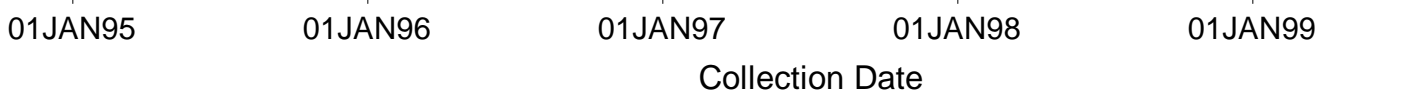


Figure 34

Burial Ground North Filter Paper Sr-89,90 (Annual Sample)

\author{
Baseline Data Plots for Environmental $\mathrm{Ai}$ \\ SDN = 64 : Location $=$ Burial Ground North $:$ Nuclide $=$ Sr-89,90
}

$1.48 \mathrm{E}-03-$

$1.38 \mathrm{E}-03-$

$1.28 \mathrm{E}-03-$

$1.18 \mathrm{E}-03$

¿

ष $1.08 \mathrm{E}-03-$

$\subseteq$

드 $9.84 \mathrm{E}-04-$

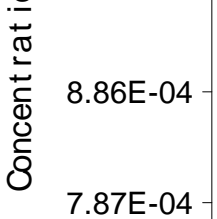

$6.89 \mathrm{E}-04$

$5.90 \mathrm{E}-04$

4.92E-04 -

01JAN95

01JAN96

01JAN97

01JAN98

01JAN99

Collection Date 
Figure 35

\section{Burial Ground North Filter Paper Gross Beta (Weekly Sample)}

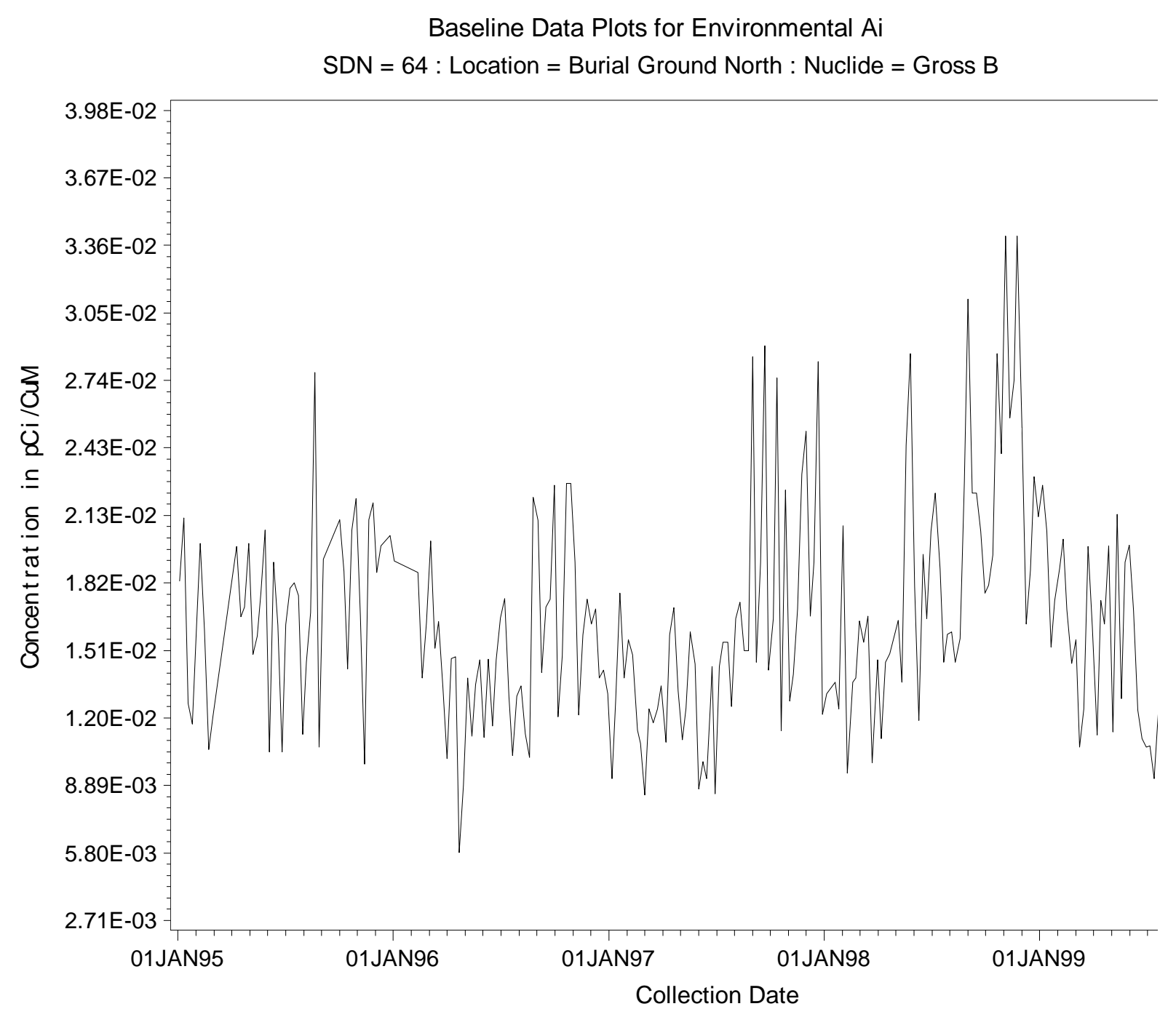


Figure 36

Burial Ground North Filter Paper Gross Alpha (Weekly Sample)

Baseline Data Plots for Environmental $\mathrm{Ai}$

SDN $=64:$ Location $=$ Burial Ground North $:$ Nuclide $=$ Gross A

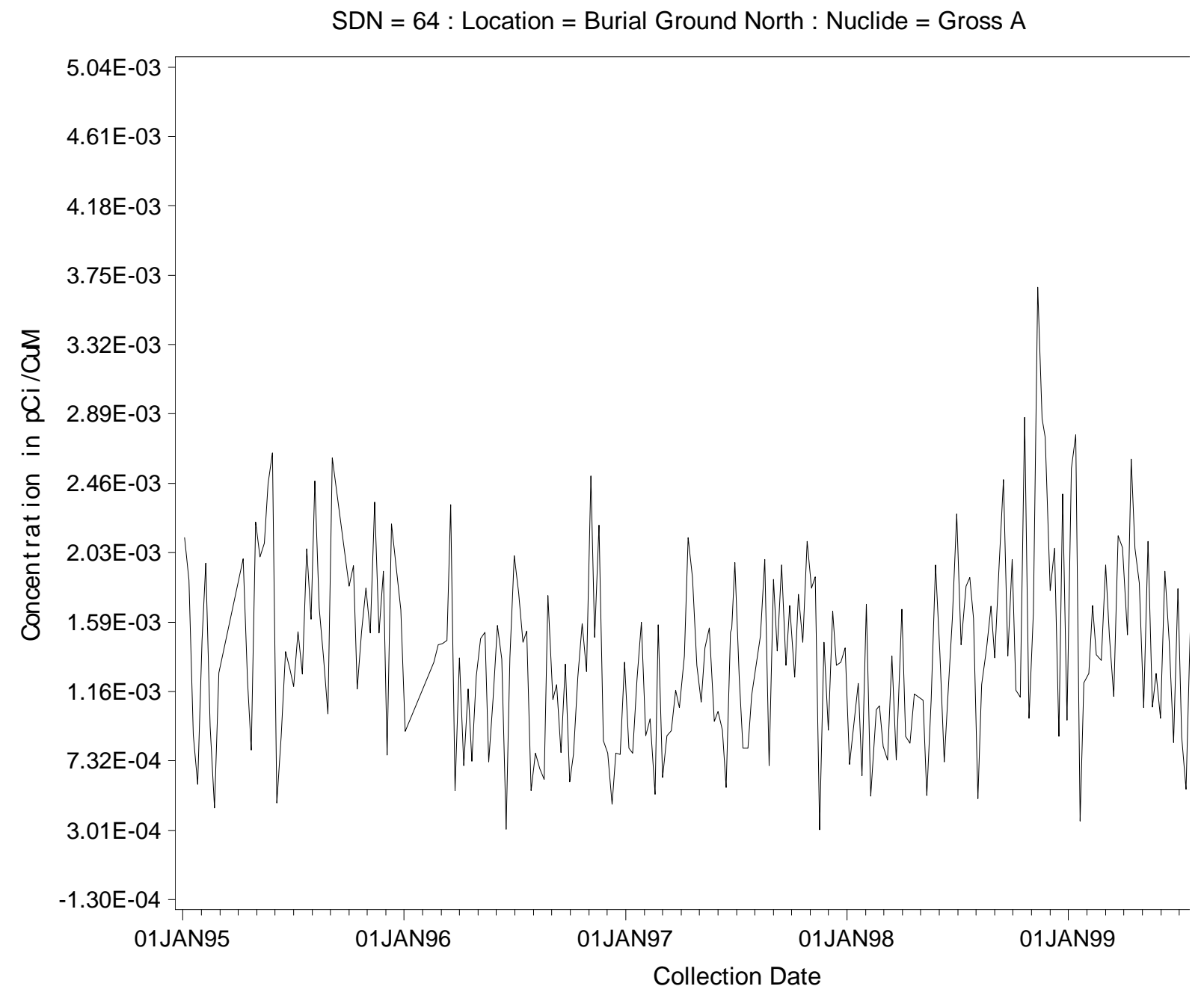


Figure 37

\section{Burial Ground North Filter Paper Co-60 (Monthly Composite)}

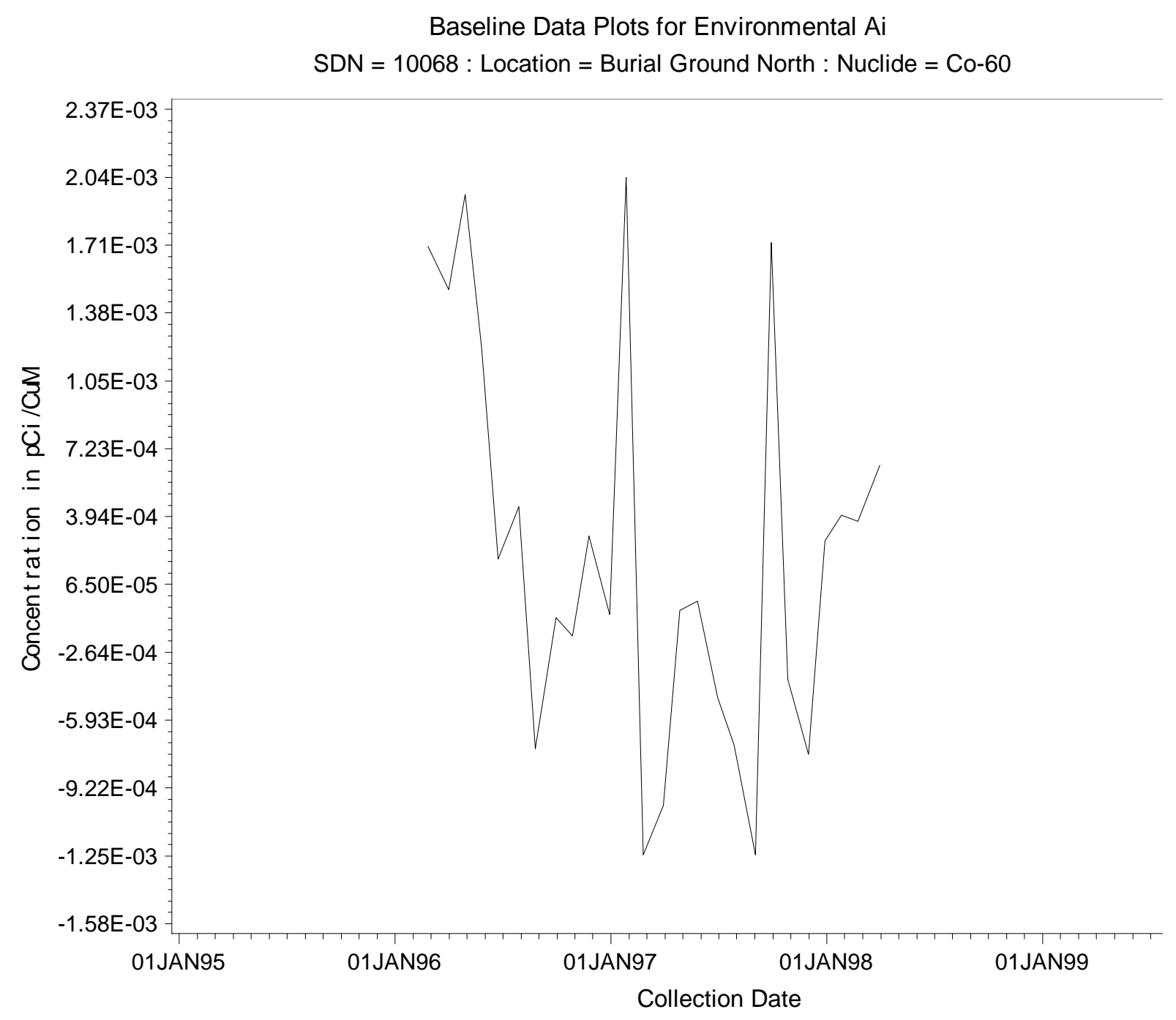


Figure 38

\section{Burial Ground North Filter Paper Cs-137 (Monthly Composite)}

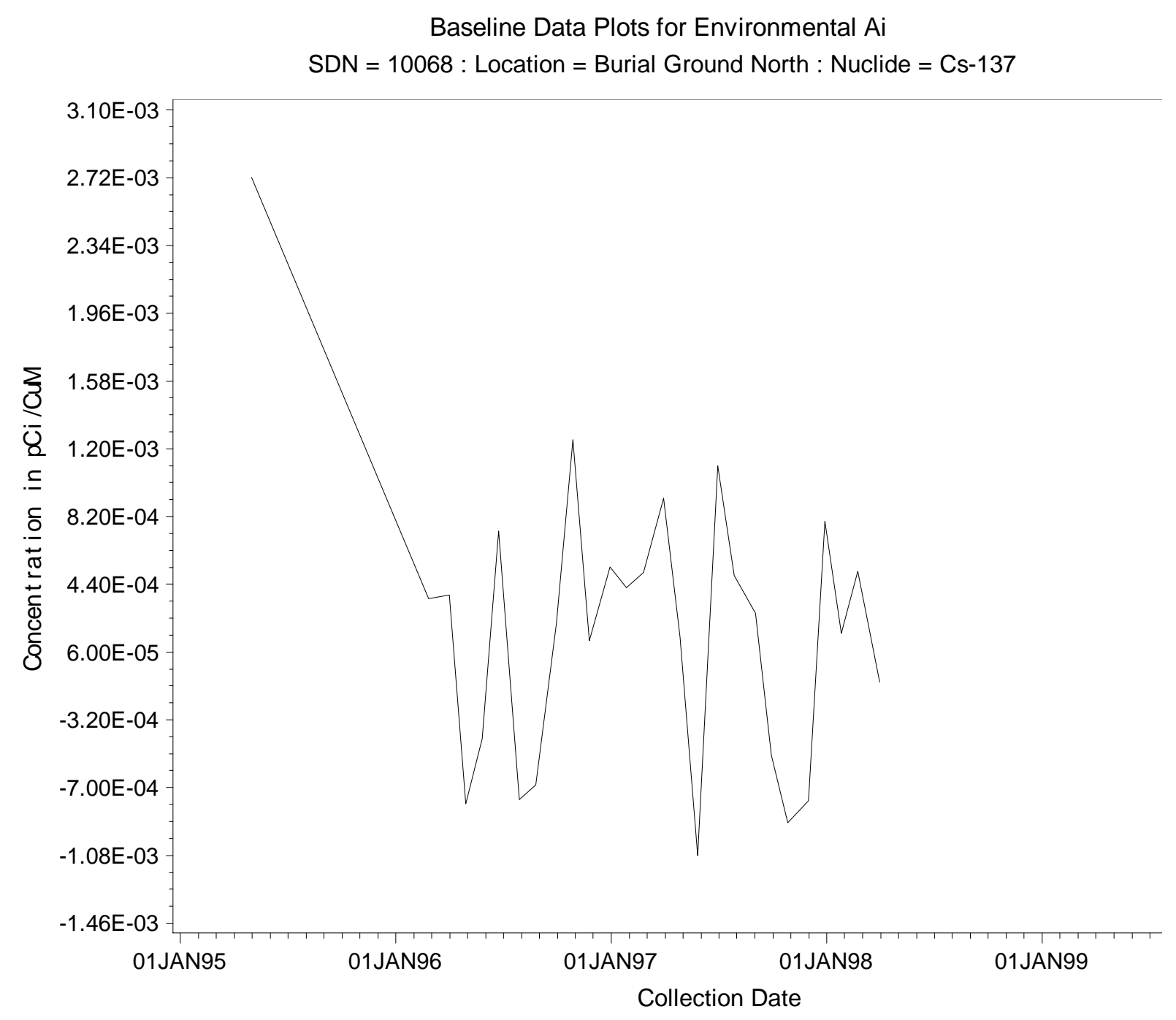


Figure 39

Burial Ground North Filter Paper Pu-238 (Monthly Composite)

Baseline Data Plots for Environmental Ai

SDN $=10068:$ Location $=$ Burial Ground North $:$ Nuclide $=$ Pu-238

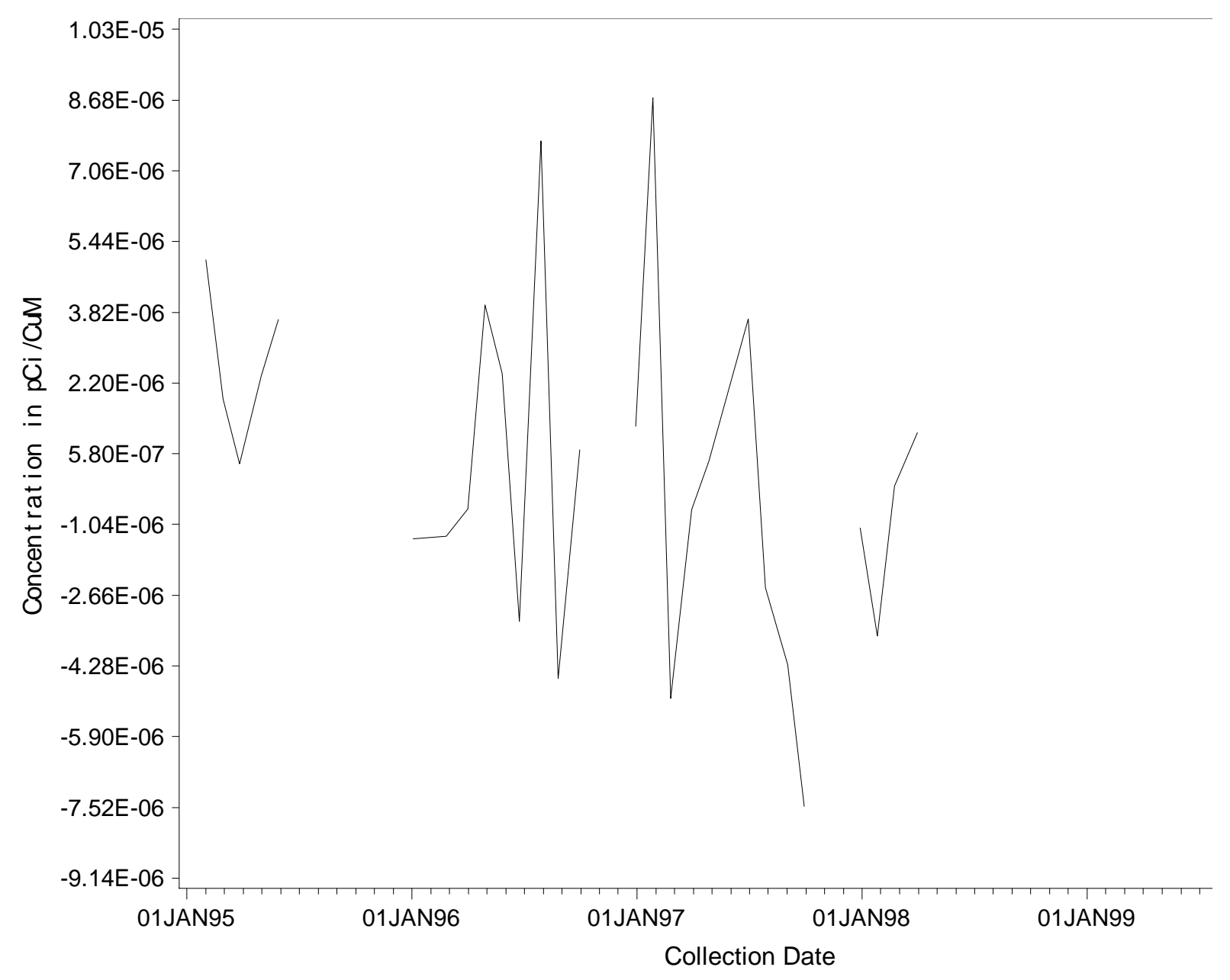


Figure 40

Burial Ground North Filter Paper Pu-239 (Monthly Composite)

Baseline Data Plots for Environmental Ai

SDN $=10068:$ Location $=$ Burial Ground North $:$ Nuclide $=$ Pu-239

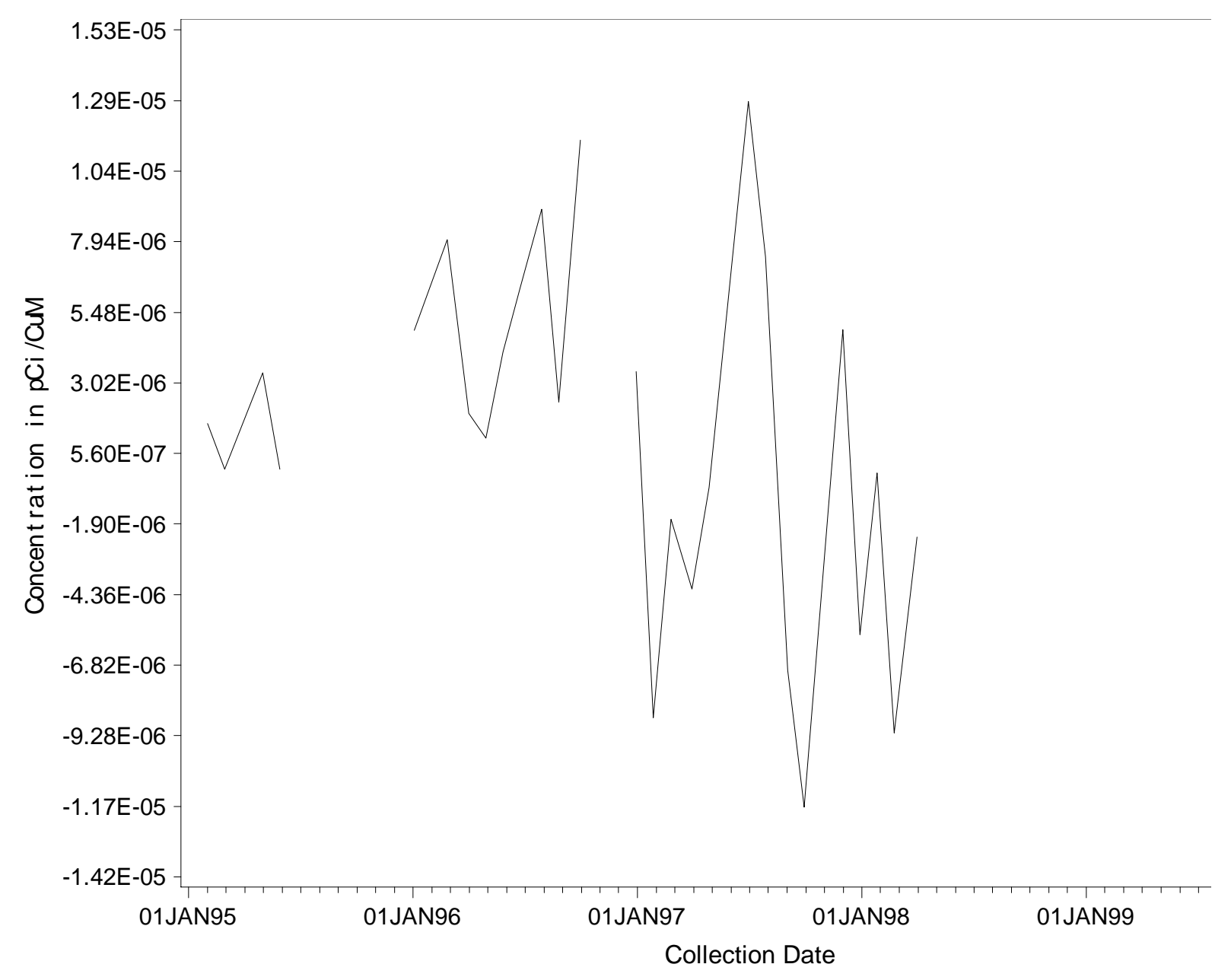




\section{Figure 41}

\section{Burial Ground North Filter Paper Sr-89,90 (Monthly Composite)}

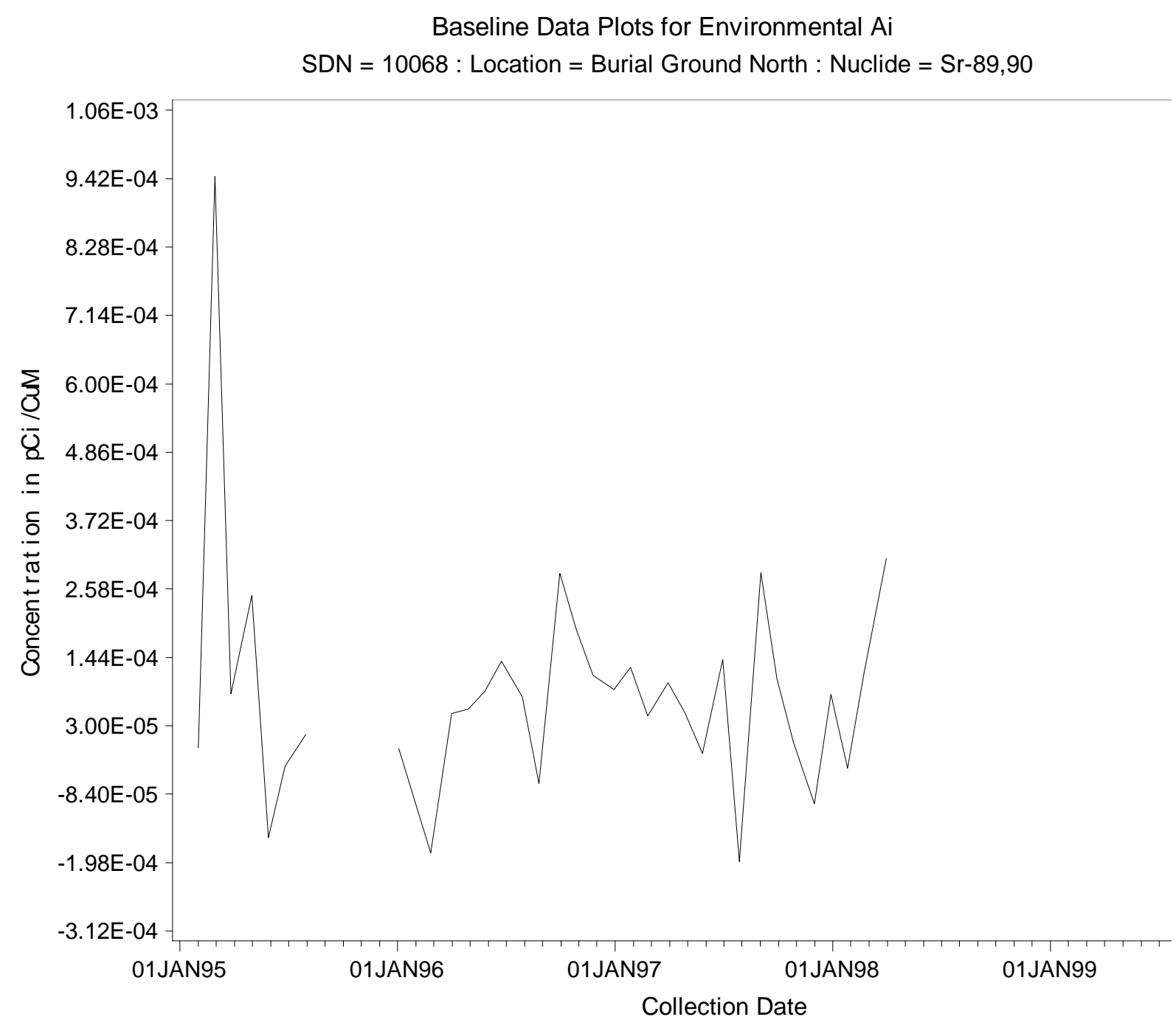


Figure 42

\section{Burial Ground North Charcoal Canister Co-60 (Weekly Sample)}

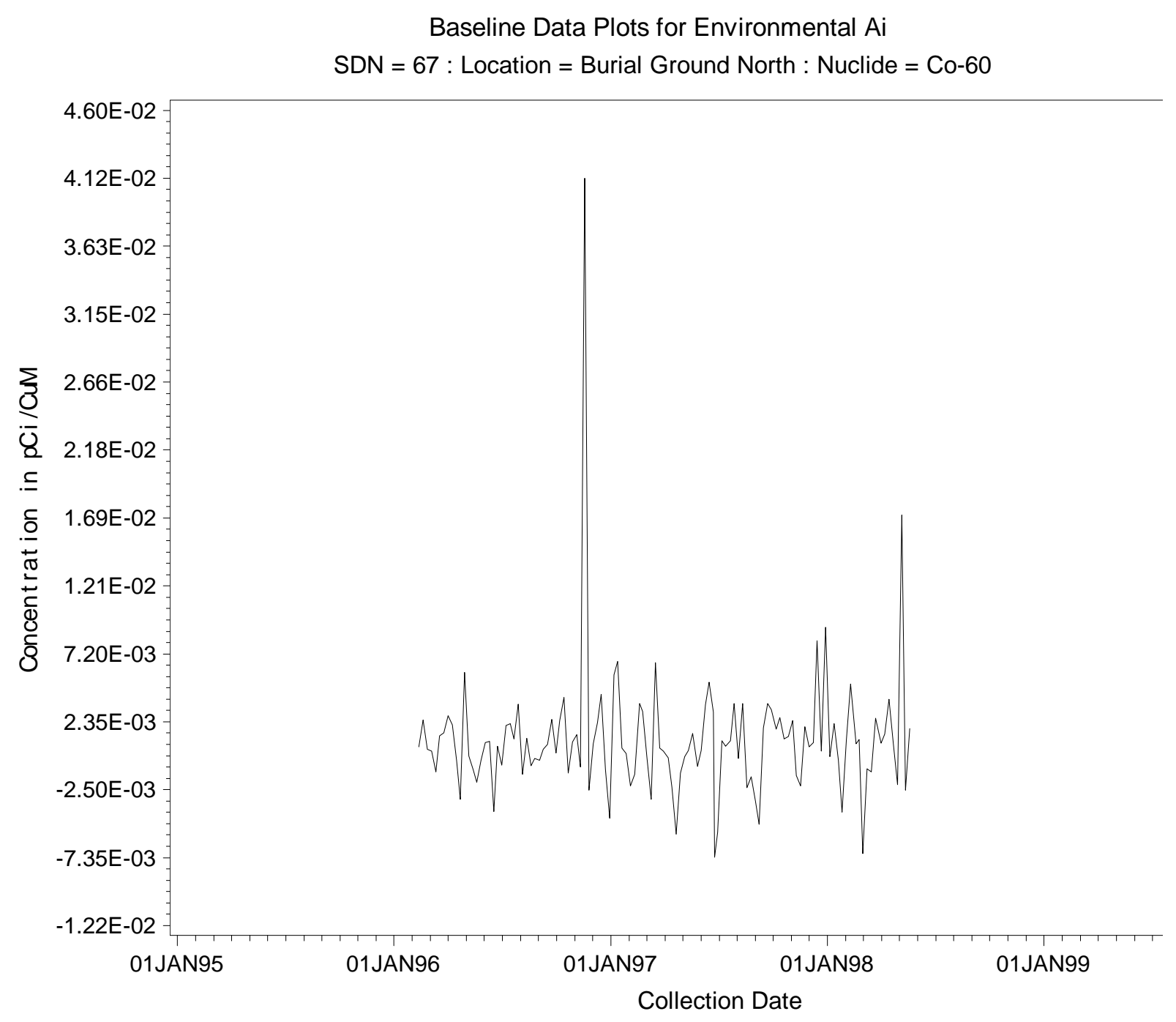


Figure 43

Burial Ground North Charcoal Canister Co-137 (Weekly Sample)

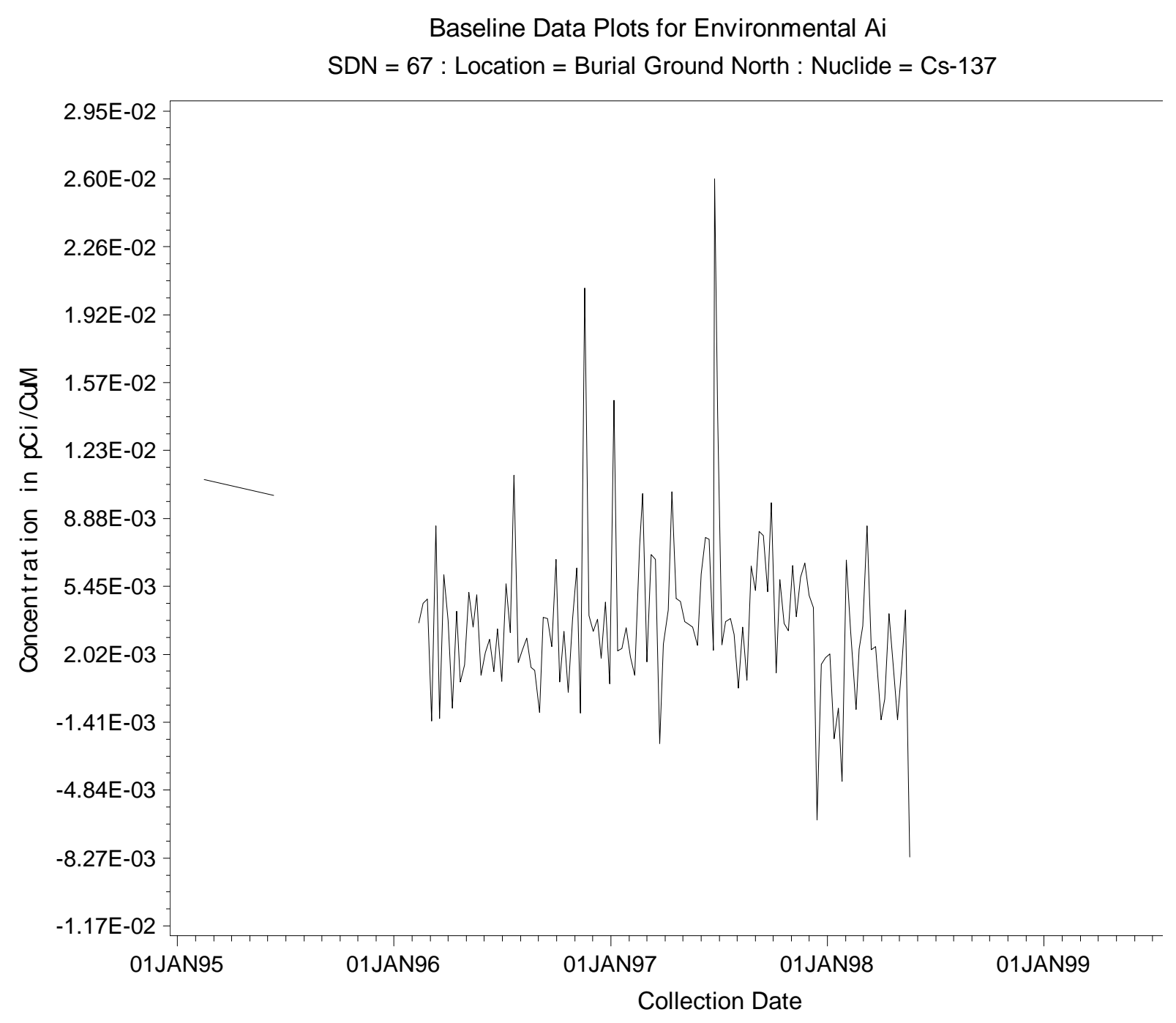


Figure 44

Burial Ground North Silica Gel H-3 (Biweekly Sample)

\author{
Baseline Data Plots for Environmental Ai \\ SDN $=82:$ Location $=$ Burial Ground North $:$ Nuclide $=\mathrm{H}-3$
}

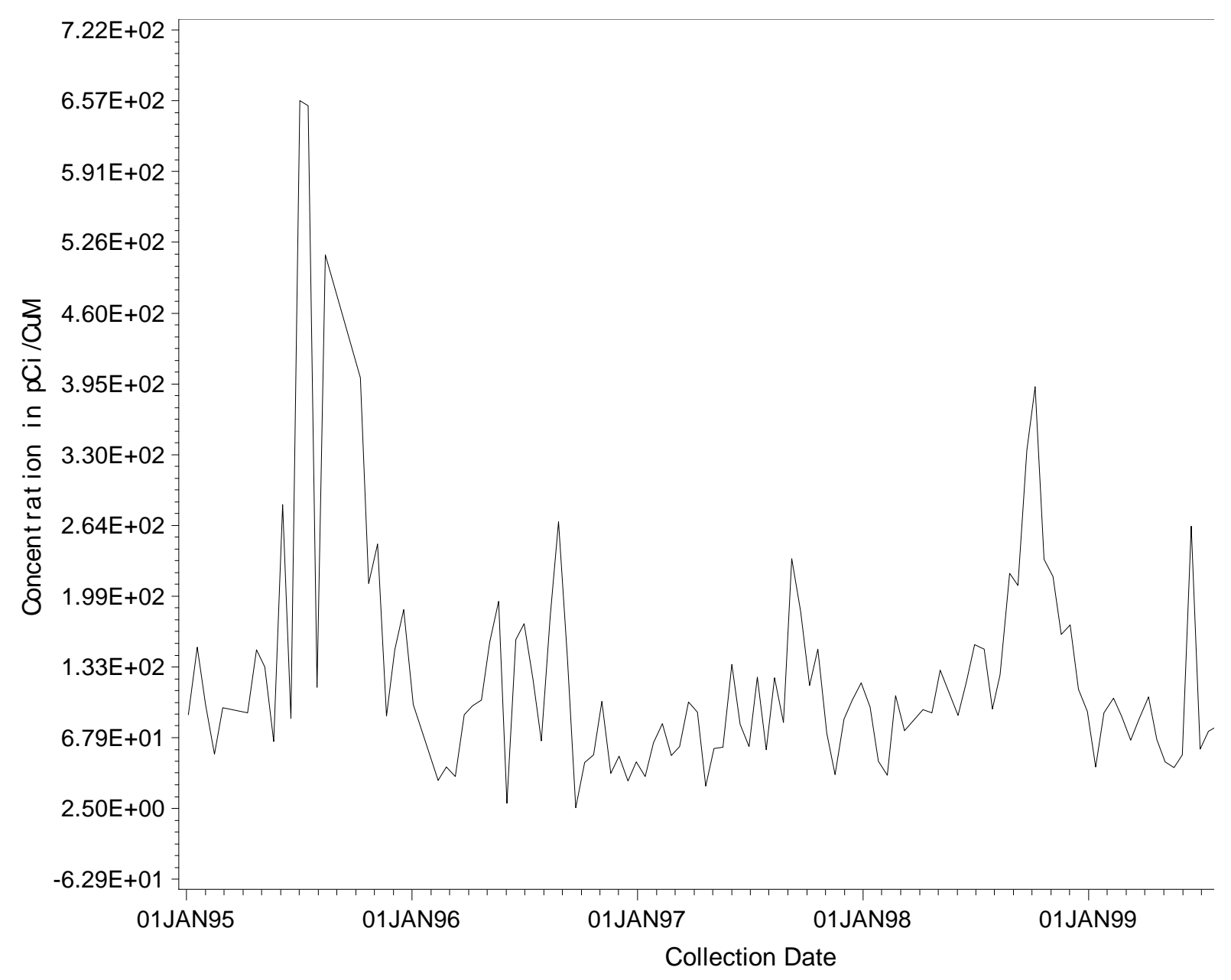




\section{Figure 45}

\section{Burial Ground North Rain Water H-3 (Biweekly Sample)}

Baseline Data Plots for Rainwater

SDN $=1481:$ Location $=$ Burial Ground North $:$ Nuclide $=\mathrm{H}-3$

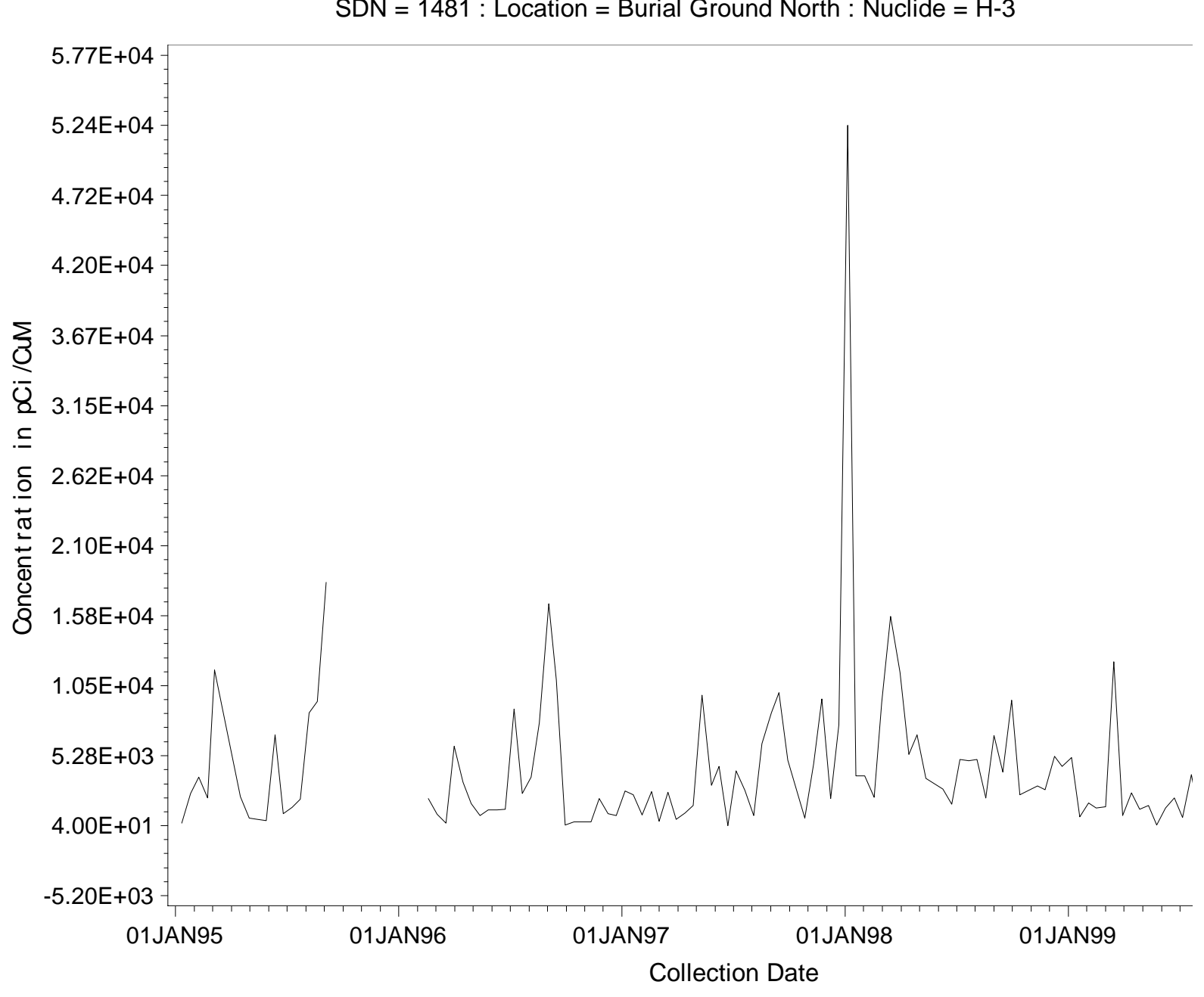


Figure 46

\section{U.S. Highway 301 Filter Paper Co-60 (Weekly Sample)}

Baseline Data Plots for Environmental $\mathrm{Ai}$

SDN = $195:$ Location = Highway $301 @$ State Line $:$ Nuclide = Co-60

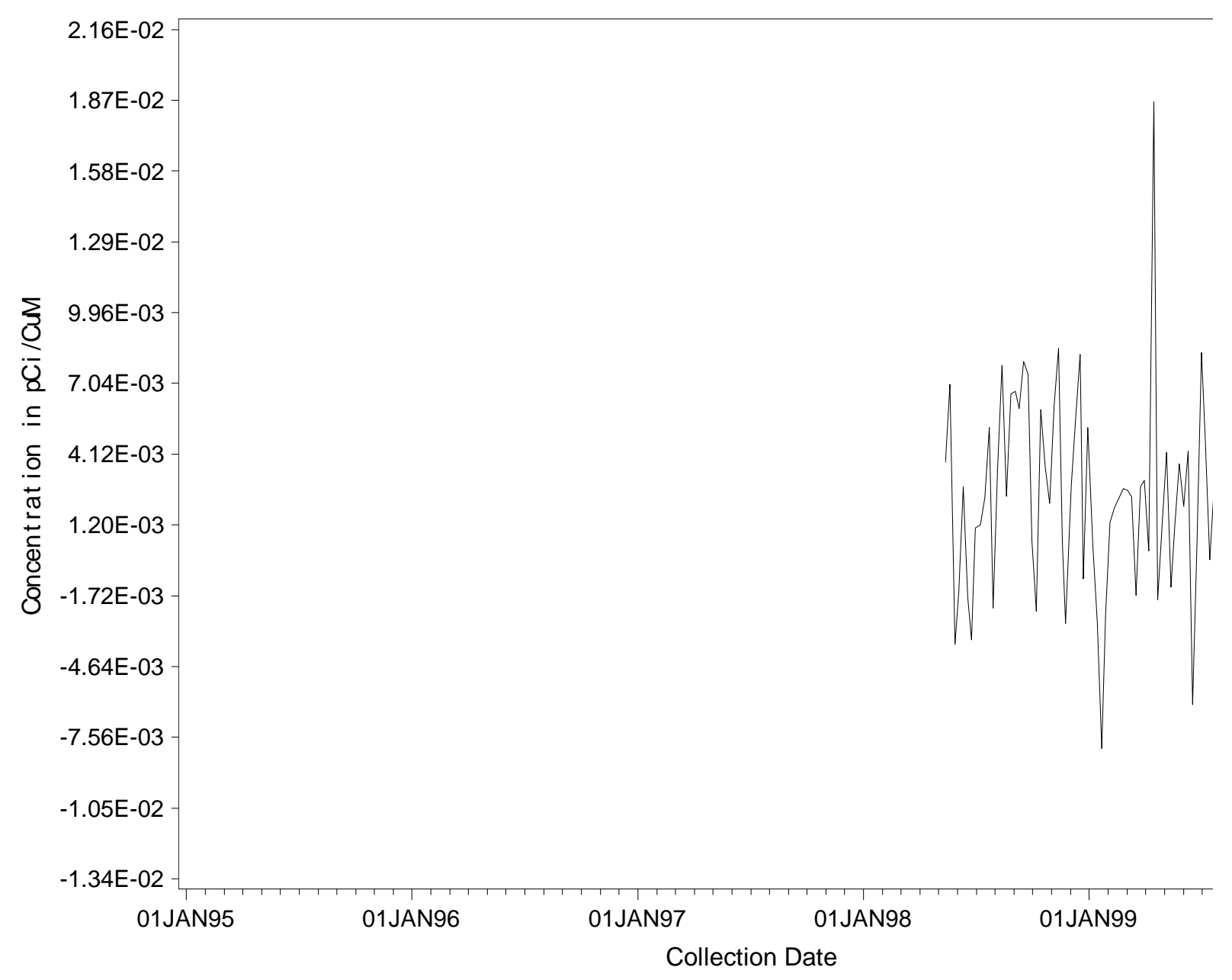


Figure 47

\section{U.S. Highway 301 Filter Paper Co-137 (Weekly Sample)}

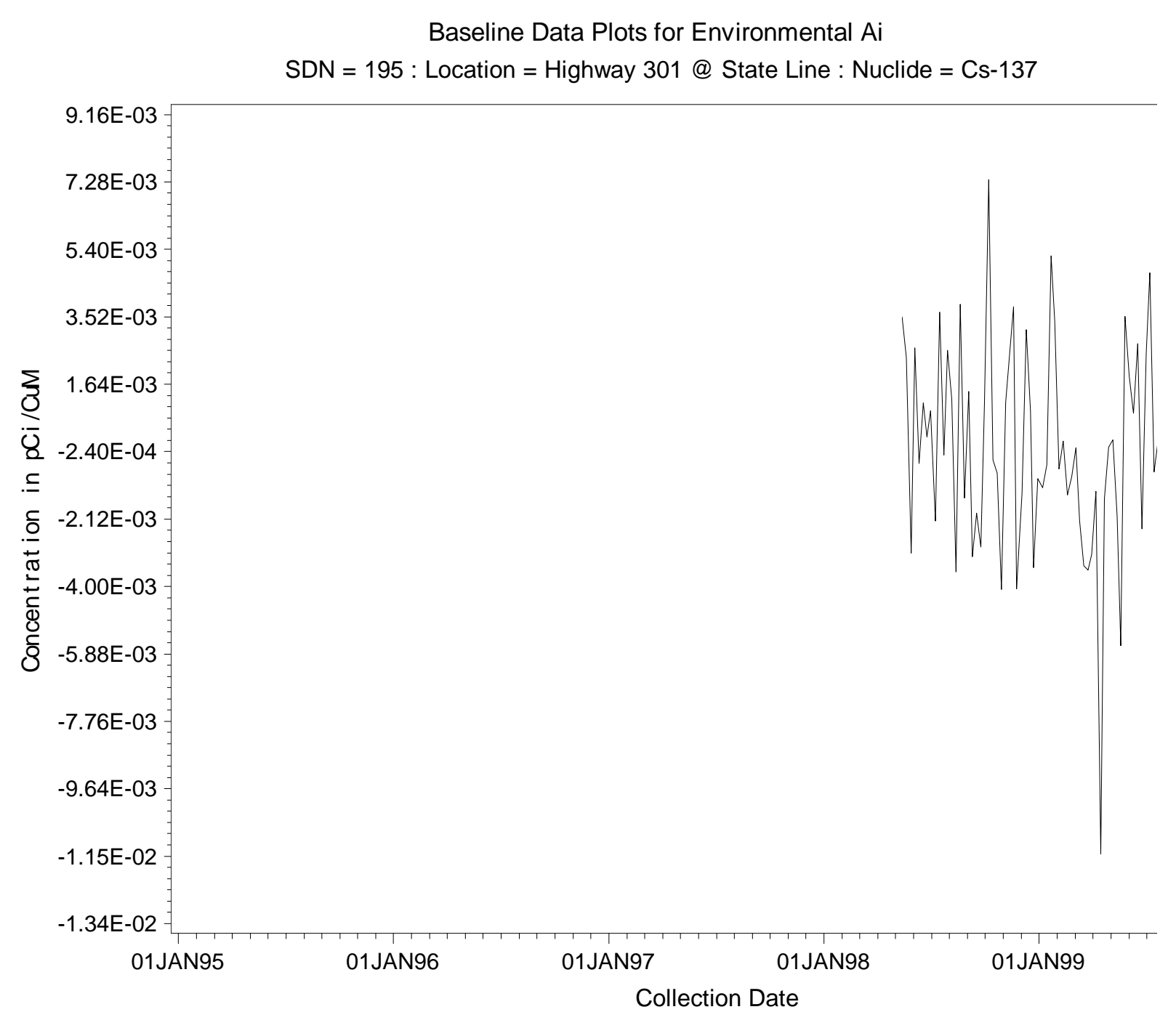




\section{Figure 48}

\section{U.S. Highway 301 Filter Paper U-234 (Annual Sample)}

Baseline Data Plots for Environmental Ai

SDN = $195:$ Location = Highway $301 @$ State Line $:$ Nuclide = U-234

$1.27 \mathrm{E}-05-$

$1.10 \mathrm{E}-05$

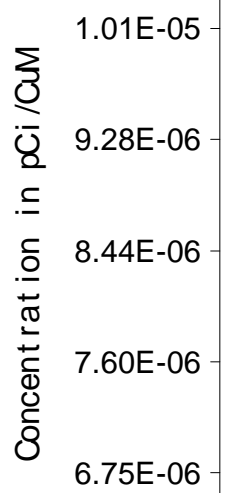

$5.91 \mathrm{E}-06-$

$5.06 \mathrm{E}-06-$

4.22E-0601JAN95 01JAN96 01JAN97 01JAN98 01JAN99

Collection Date 


\section{Figure 49}

\section{U.S. Highway 301 Filter Paper U-235 (Annual Sample)}

Baseline Data Plots for Environmental Ai

SDN = $195:$ Location = Highway $301 @$ State Line $:$ Nuclide = U-235

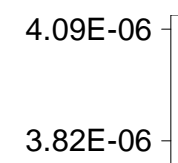


Figure 50

U.S. Highway 301 Filter Paper U-238 (Annual Sample)

Baseline Data Plots for Environmental Ai

SDN = $195:$ Location = Highway $301 @$ State Line $:$ Nuclide = U-238

$9.64 \mathrm{E}-06-\overline{\mathrm{C}}-06-$
$9.00 \mathrm{E}-$

\begin{abstract}
8.35E-06-
\end{abstract}

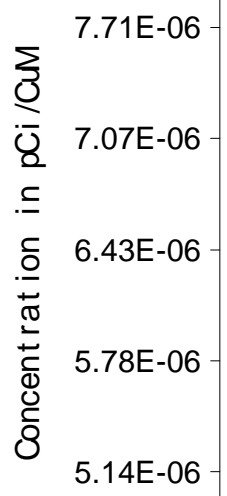

4.50E-06-

3.85E-06-

3.21E-0601JAN95 01JAN96 01JAN97 01JAN98 01JAN99

Collection Date 
Figure 51

\section{U.S. Highway 301 Filter Paper Pu-238 (Annual Sample)}

Baseline Data Plots for Environmental Ai

SDN = 195 : Location = Highway $301 @$ State Line $:$ Nuclide = Pu-238

$-6.63 \mathrm{E}-06-\overline{\mathrm{C}}-\mathrm{C}-06-$
$-6.19 \mathrm{E}-$

$-5.75 \mathrm{E}-06$

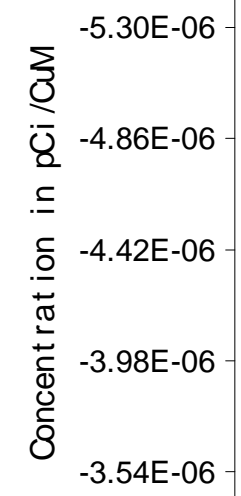

$-3.09 E-06-$

$-2.65 \mathrm{E}-06-$

$-2.21 \mathrm{E}-06-$

01JAN95

01JAN96

01JAN97

01JAN98

01JAN99

Collection Date 
Figure 52

\section{U.S. Highway 301 Filter Paper Pu-239 (Annual Sample)}

Baseline Data Plots for Environmental Ai

SDN = 195 : Location = Highway $301 @$ State Line $:$ Nuclide = Pu-239

2.16E-06 -

2.02E-06-

1.87E-06-

$1.73 \mathrm{E}-06$

$\sum_{0}$

¿ृ $1.58 \mathrm{E}-06-$

$\subseteq$

드 $1.44 \mathrm{E}-06-$

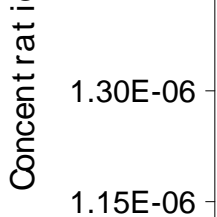

$1.01 \mathrm{E}-06$

8.64E-07-

7.20E-07 -

01JAN95

01JAN96

01JAN97

01JAN98

01JAN99

Collection Date 
Figure 53

\section{U.S. Highway 301 Filter Paper Am-241 (Annual Sample)}

Baseline Data Plots for Environmental Ai

SDN = $195:$ Location = Highway $301 @$ State Line $:$ Nuclide = Am-241

2.16E-05-

2.02E-05 -

1.87E-05 -

1.73E-05 -

$\sum$

ষ 1.59E-05-

드

드 $1.44 \mathrm{E}-05-$

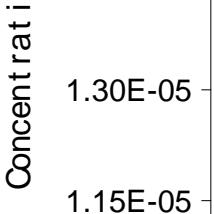

1.01E-05 -

8.66E-06 -

7.22E-06 -

01JAN95

01JAN96

01JAN97

01JAN98

01JAN99

Collection Date 
Figure 54

U.S. Highway 301 Filter Paper Cm-244 (Annual Sample)

Baseline Data Plots for Environmental Ai

SDN = $195:$ Location = Highway $301 @$ State Line : Nuclide = Cm-244

1.05E-06 -

9.77E-07 -

9.07E-07-

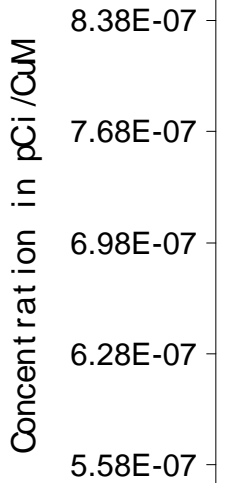

4.89E-07-

4.19E-07-

3.49E-07

01JAN95

01JAN96

01JAN97

01JAN98

01JAN99

Collection Date 


\section{Figure 55}

\section{U.S. Highway 301 Filter Paper Sr-89,90 (Annual Sample)}

\section{Baseline Data Plots for Environmental Ai}

SDN = $195:$ Location = Highway $301 @$ State Line $:$ Nuclide = Sr-89,90

\subsection{E-04 -}

8.42E-04-

7.82E-04 -

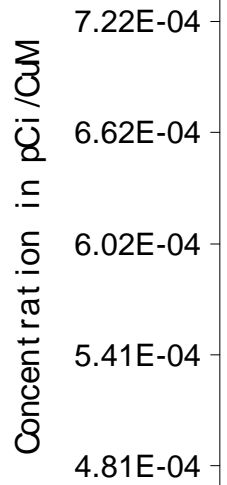

$4.21 \mathrm{E}-04$

3.61E-04 -

3.01E-04 -

01JAN95

01JAN96

01JAN97

01JAN98

01JAN99

Collection Date 
Figure 56

\section{U.S. Highway 301 Filter Paper Gross Beta (Weekly Sample)}

\section{Baseline Data Plots for Environmental Ai}

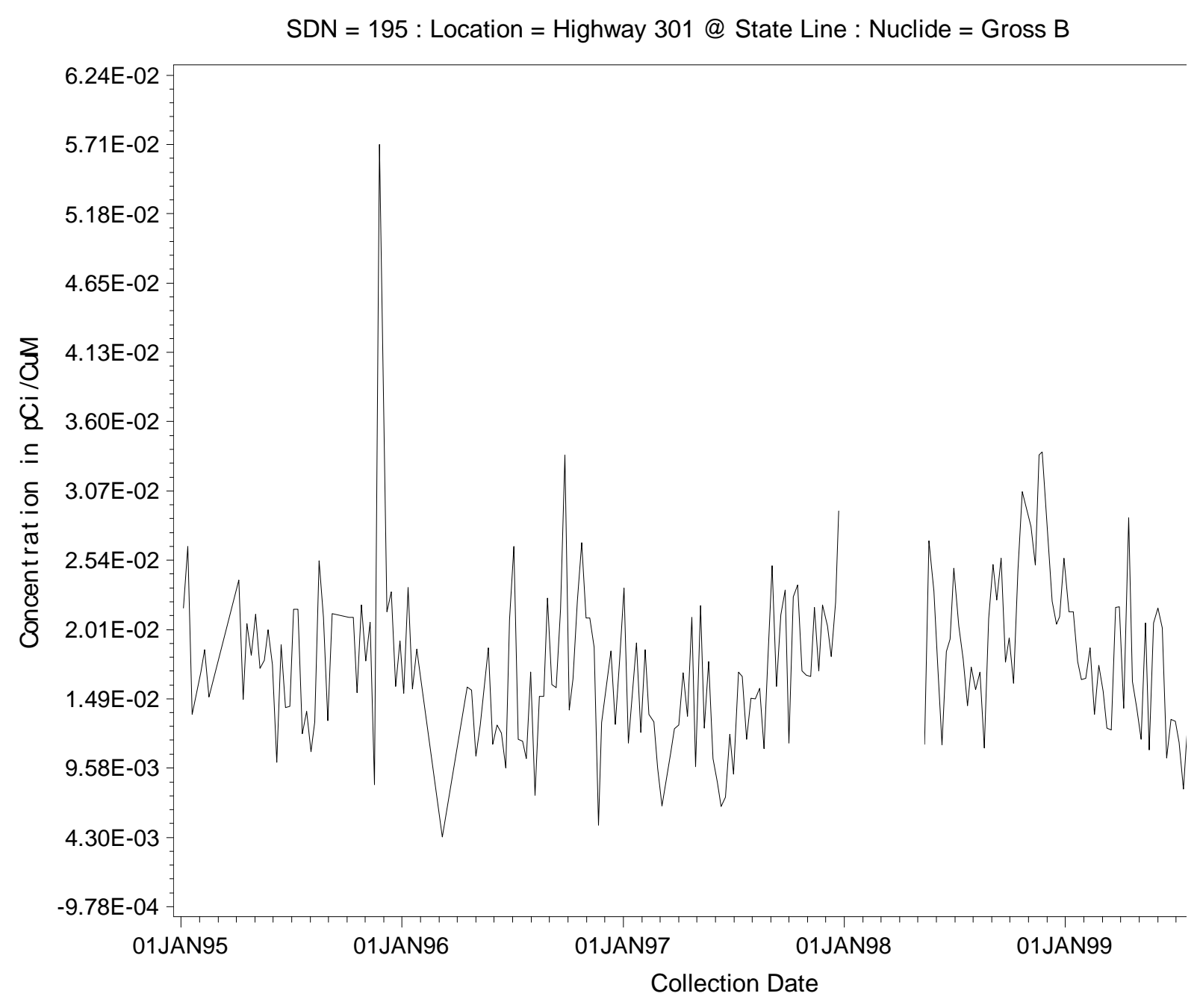


Figure 57

\section{U.S. Highway 301 Filter Paper Gross Alpha (Weekly Sample)}

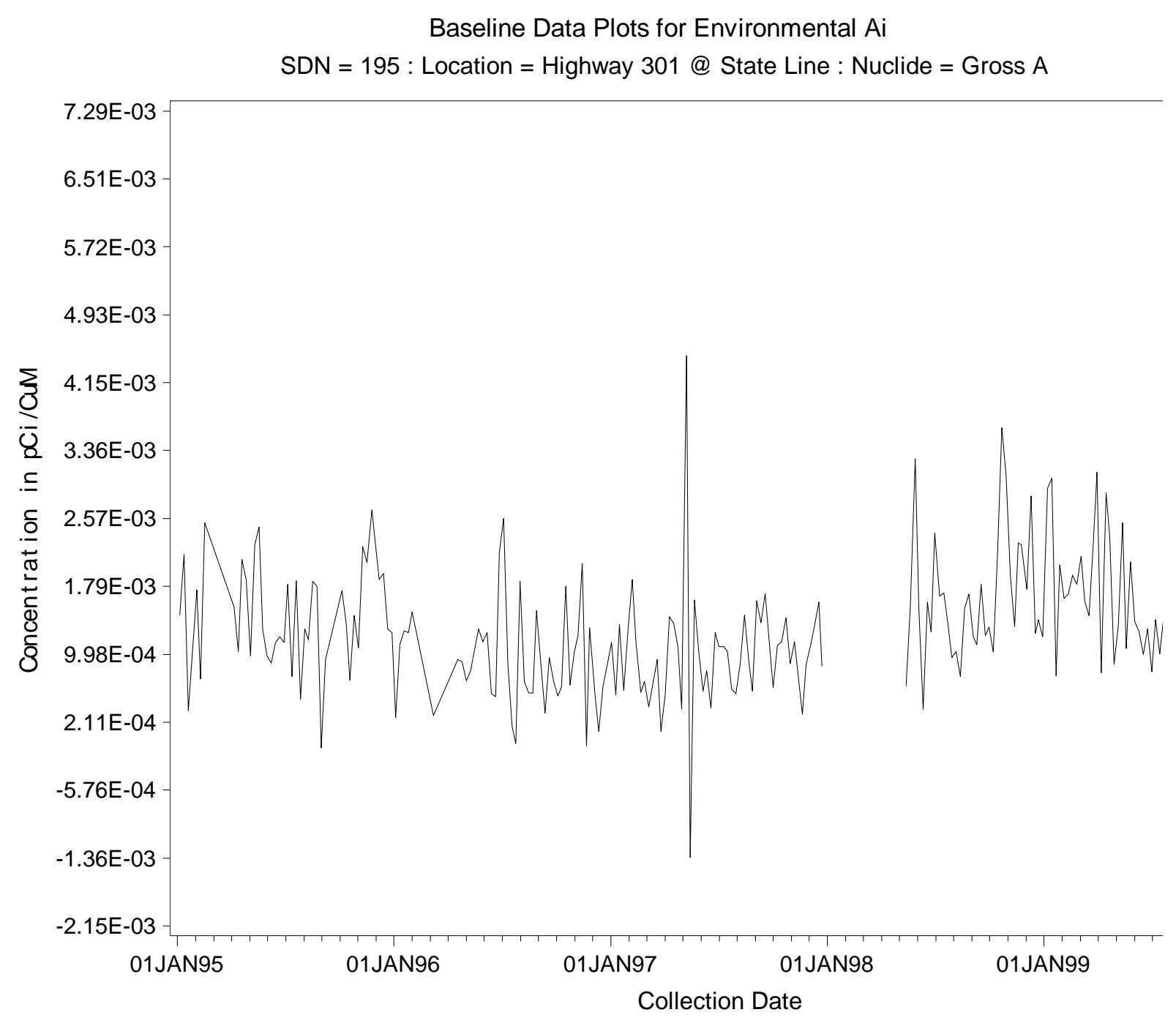


Figure 58

\section{U.S. Highway 301 Charcoal Canister Co-60 (Weekly Sample)}

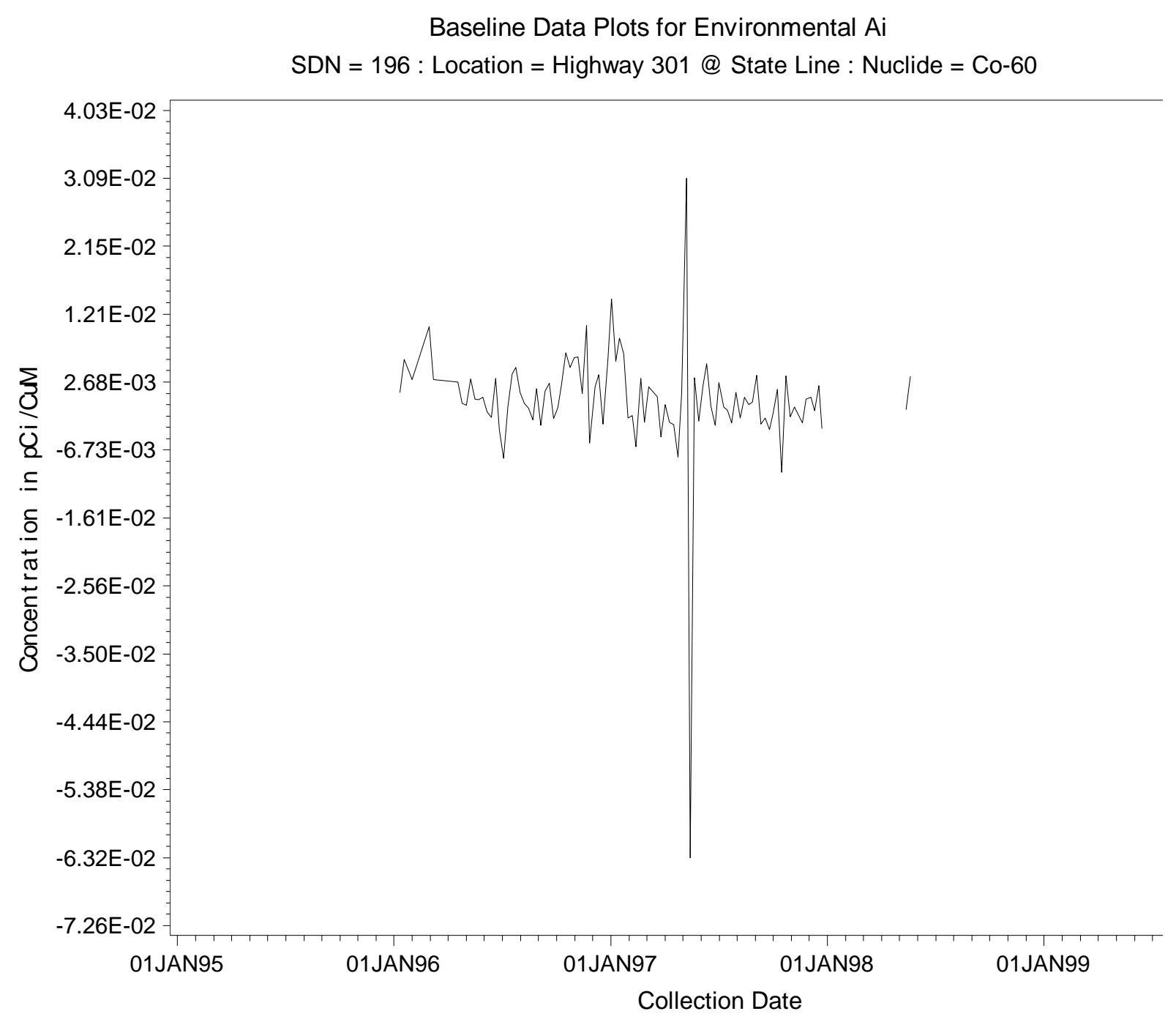


Figure 59

\section{U.S. Highway 301 Charcoal Canister Cs-137 (Weekly Sample)}

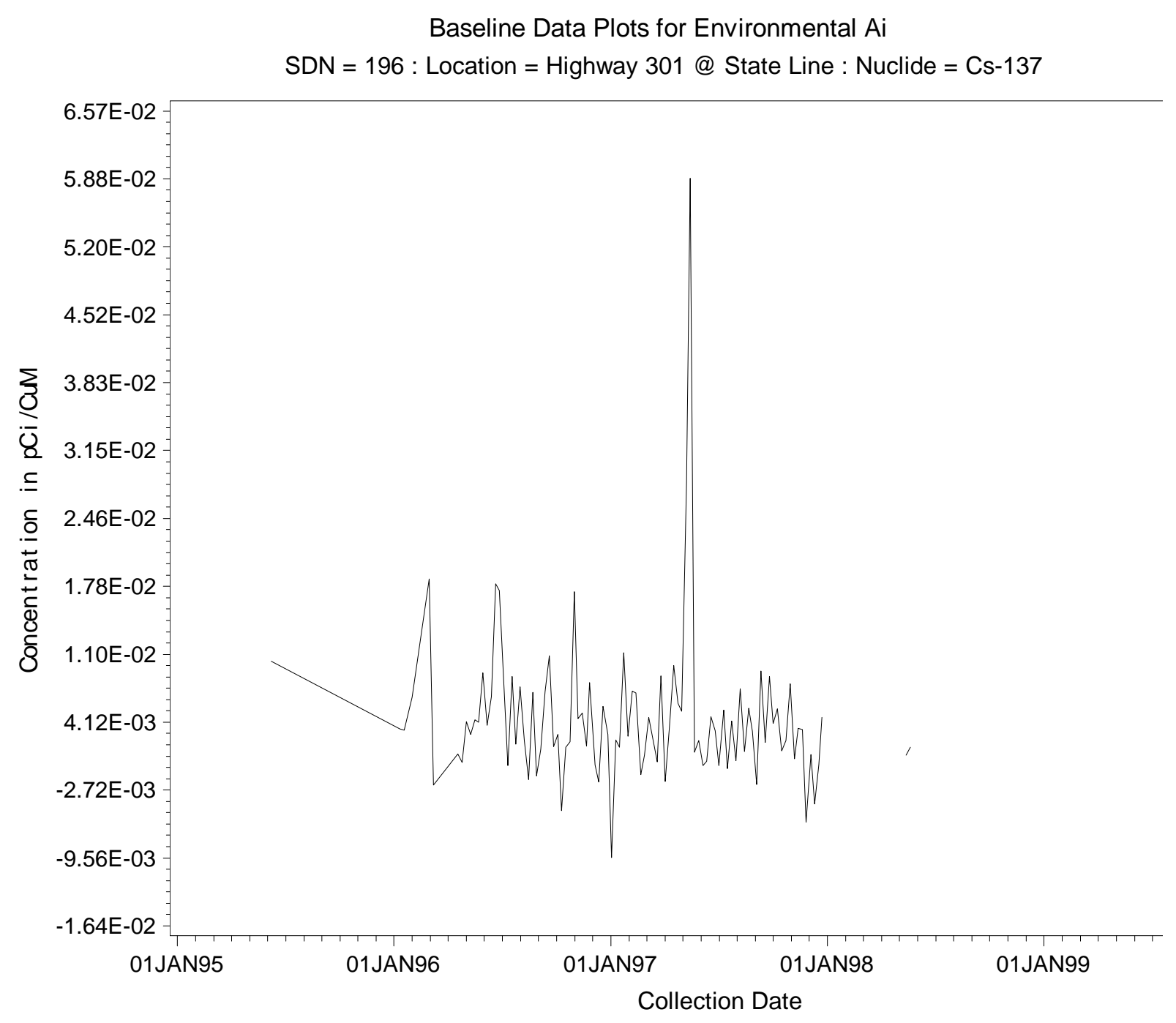


Figure 60

\section{U.S. Highway 301 Silica Gel H-3 (Biweekly Sample)}

Baseline Data Plots for Environmental Ai

SDN = 197 : Location = Highway $301 @$ State Line $:$ Nuclide = H-3

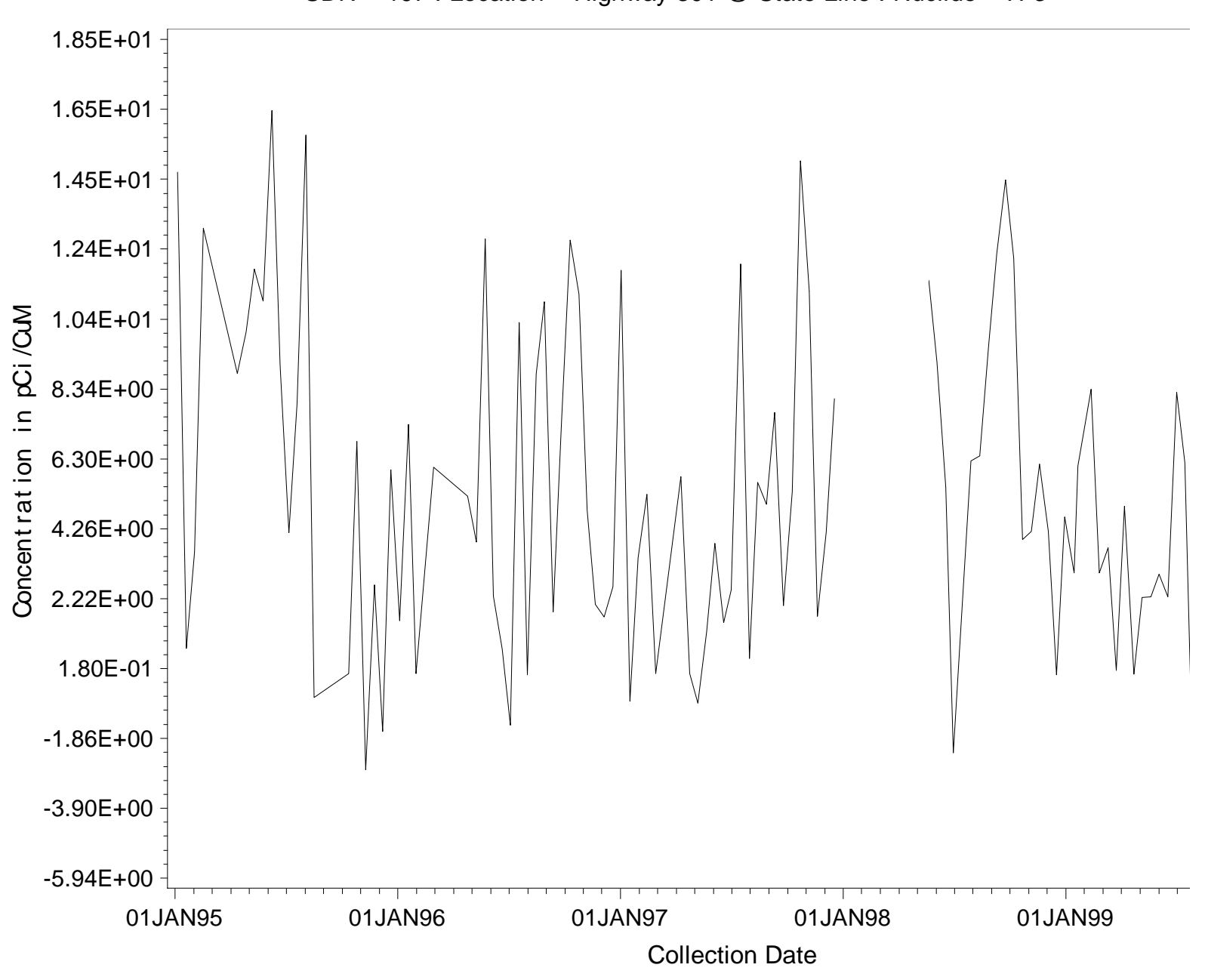

ESH-EMS-2000-849

Surplus Plutonium Disposition (SPD)

Environmental Data Summary 
Figure 61

\section{U.S. Highway 301 Rain Water H-3 (Biweekly Sample)}

\section{Baseline Data Plots for Rainwateı}

SDN = $1492:$ Location = Highway $301 @$ State Line $:$ Nuclide = H-3

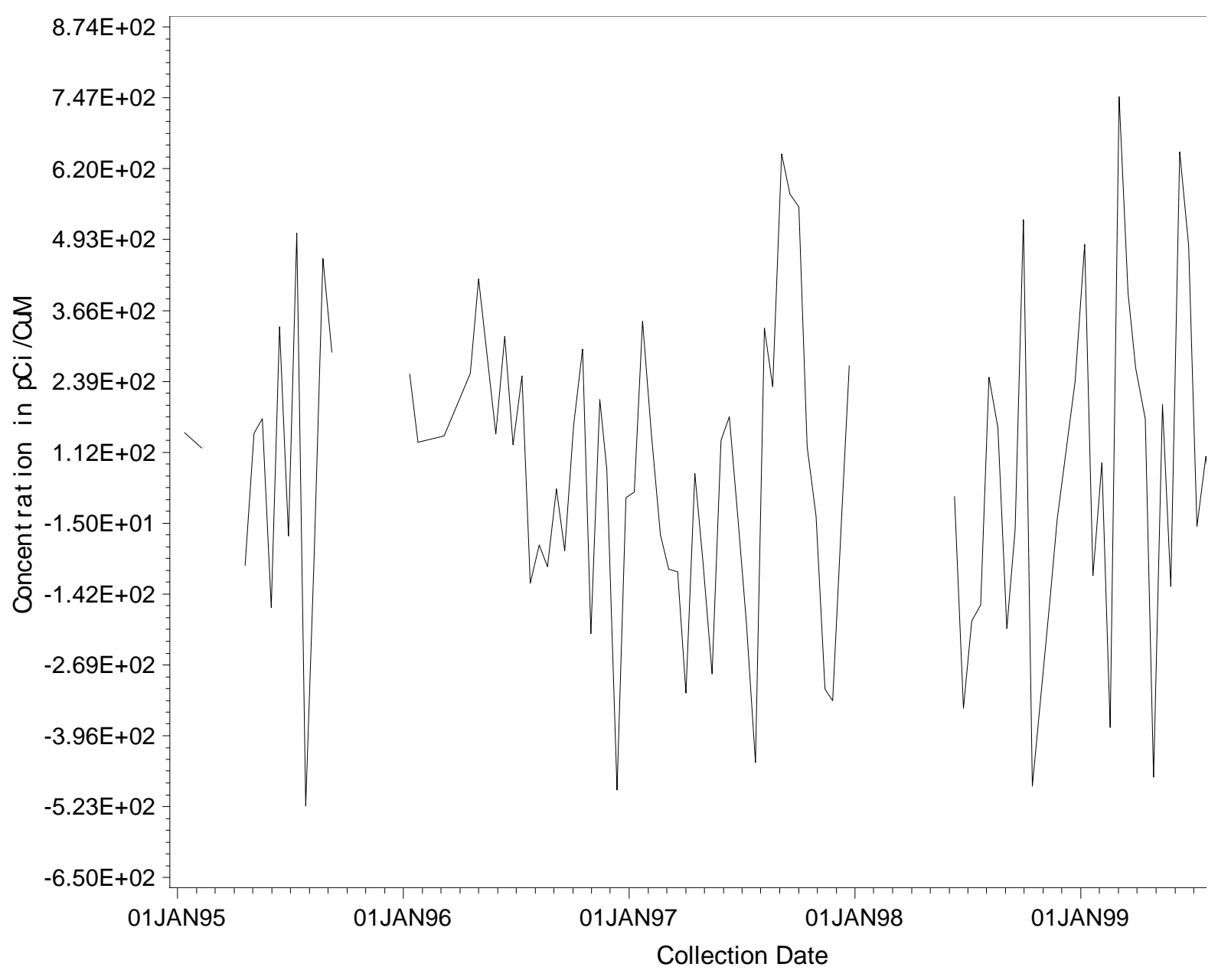

ESH-EMS-2000-849

Surplus Plutonium Disposition (SPD)

Environmental Data Summary 
Figure 62

\section{Cs-137 Concentration in Soil \\ Near F-Area}

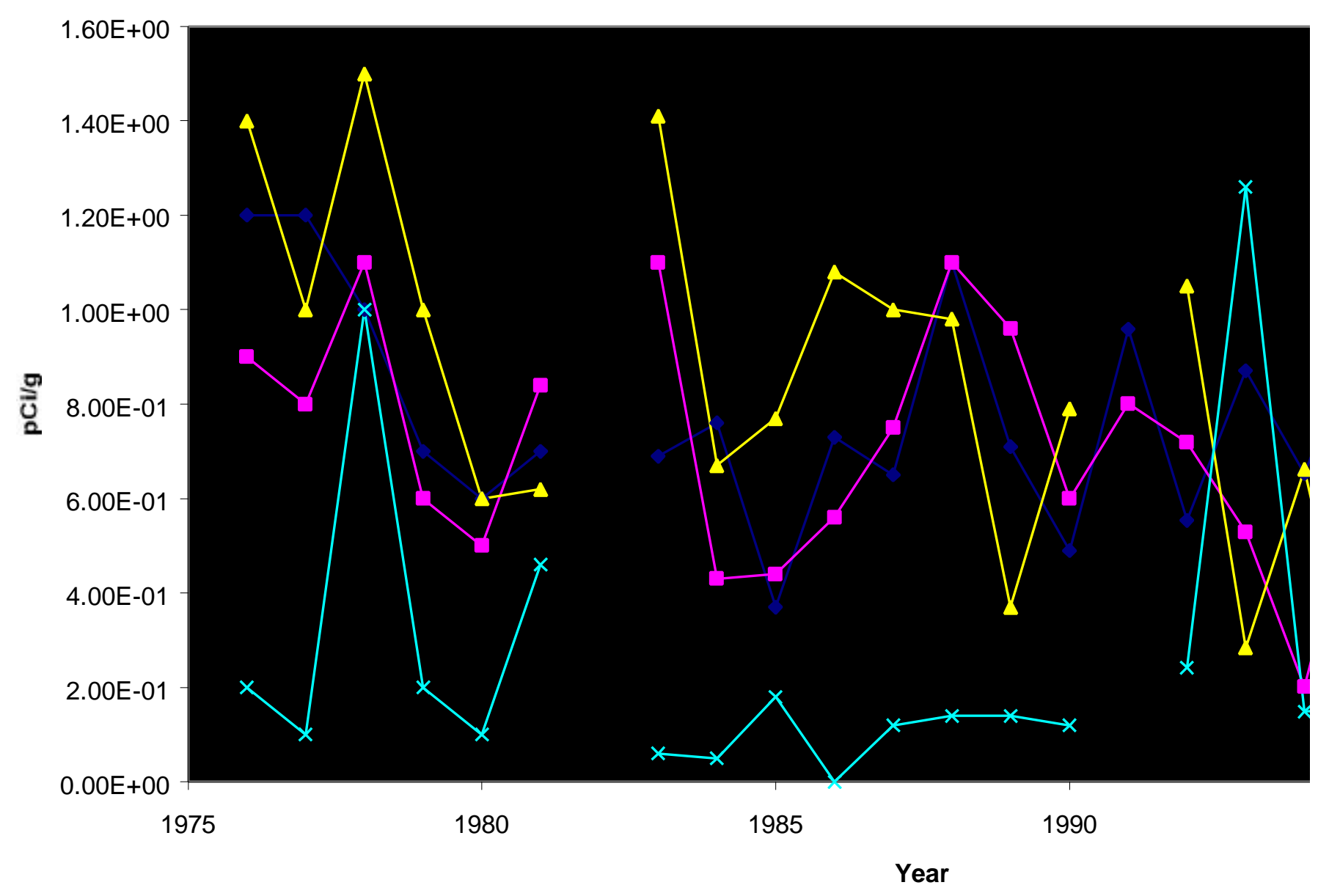

$\rightarrow$ F-Area 2000E $\rightarrow$-F-Area 2000W - F-Area 2000N $\times$ F-Area $c$ 
Figure 63

Sr-89,90 Concentration in Soil

Near F-Area

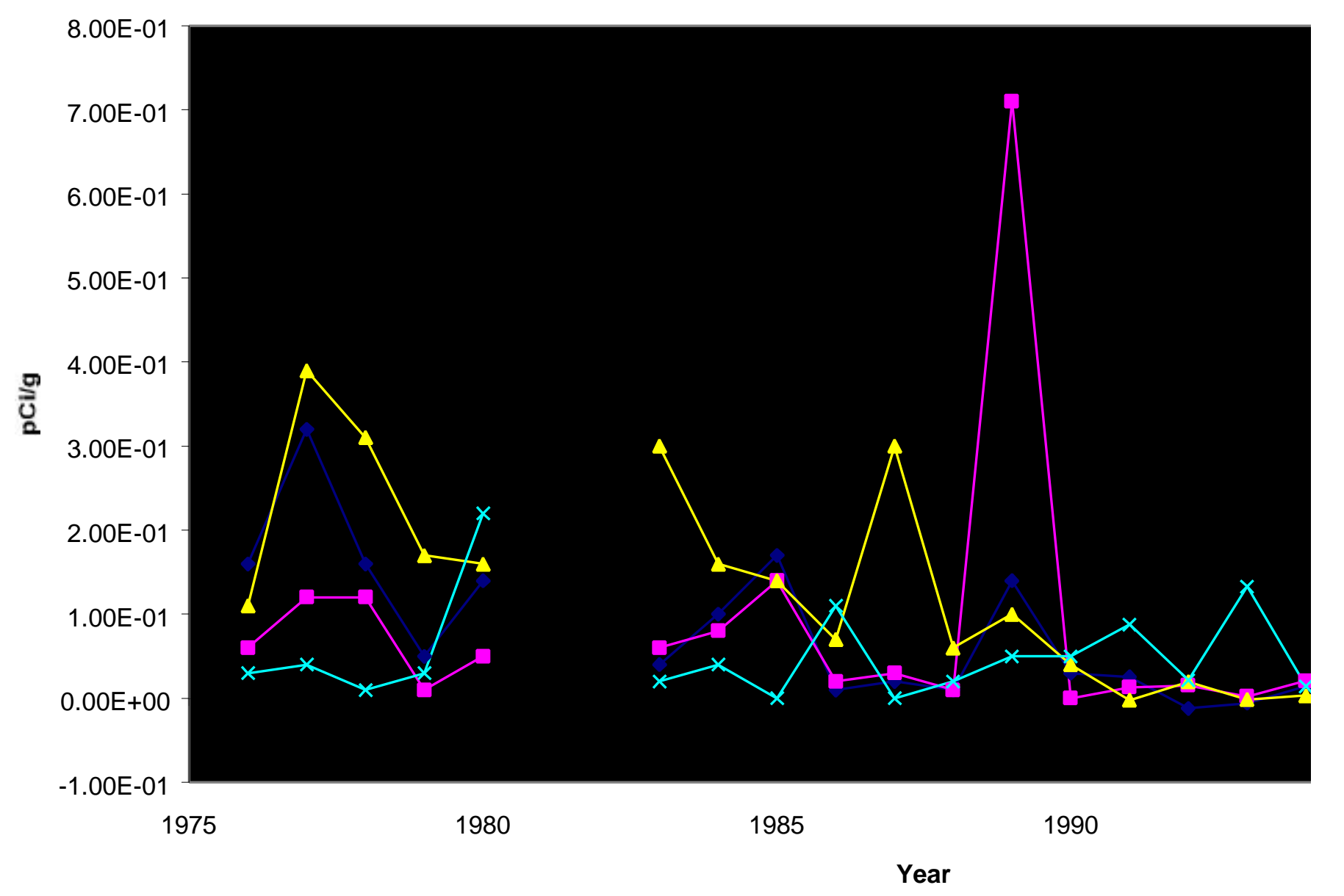

$\multimap$ F-Area 2000E $\rightarrow-$ F-Area 2000W - F-Area 2000N $*$ F-Area : 
Figure 64

Pu-238 Concentration in Soil

Near F-Area

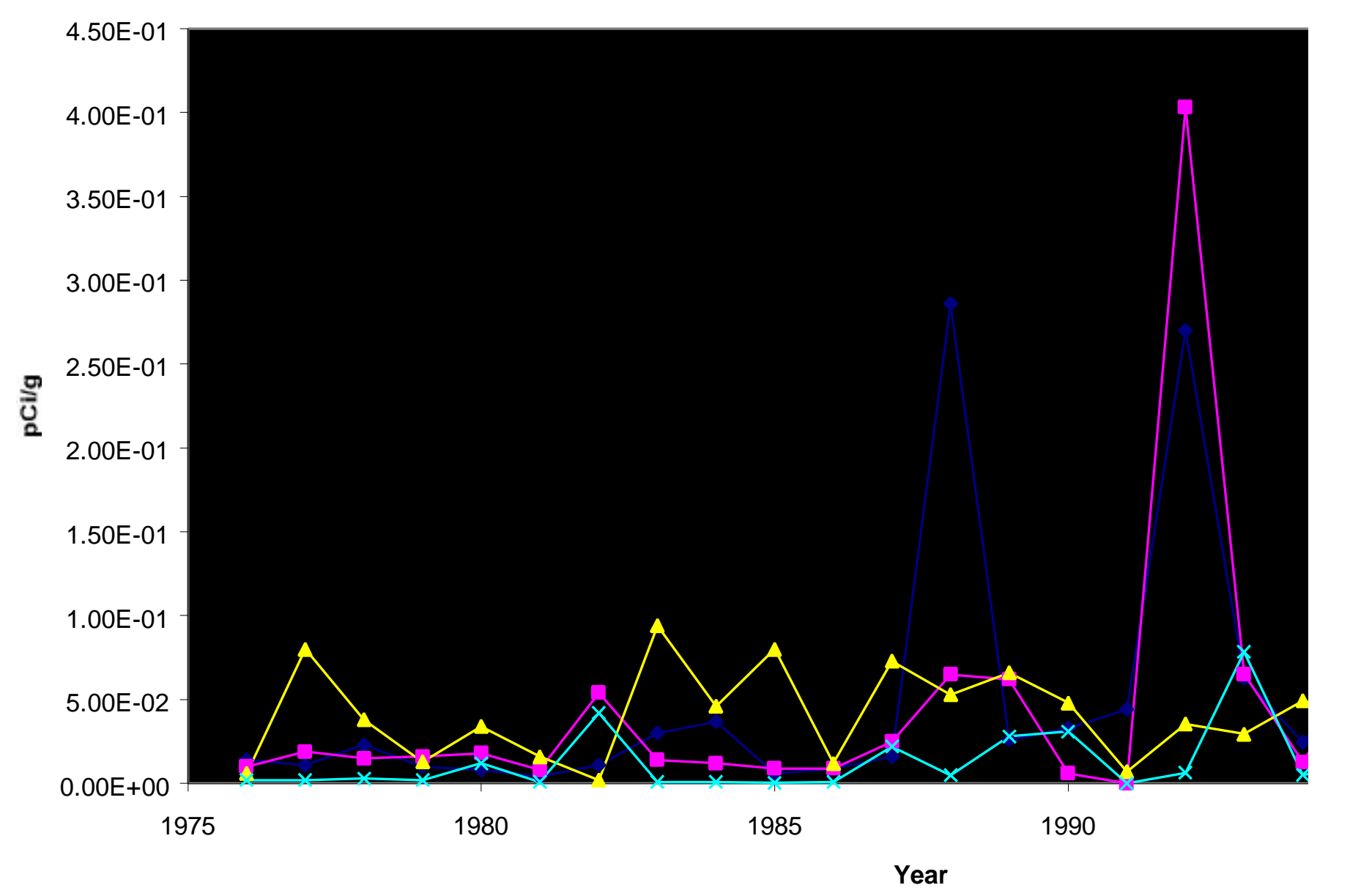

$\rightarrow-$ F-Area 2000E $\rightarrow-$ F-Area 2000W - F-Area 2000N $\rightarrow$ F-Area $c$ 
Figure 65

Pu-239 Concentration in Soil

Near F-Area

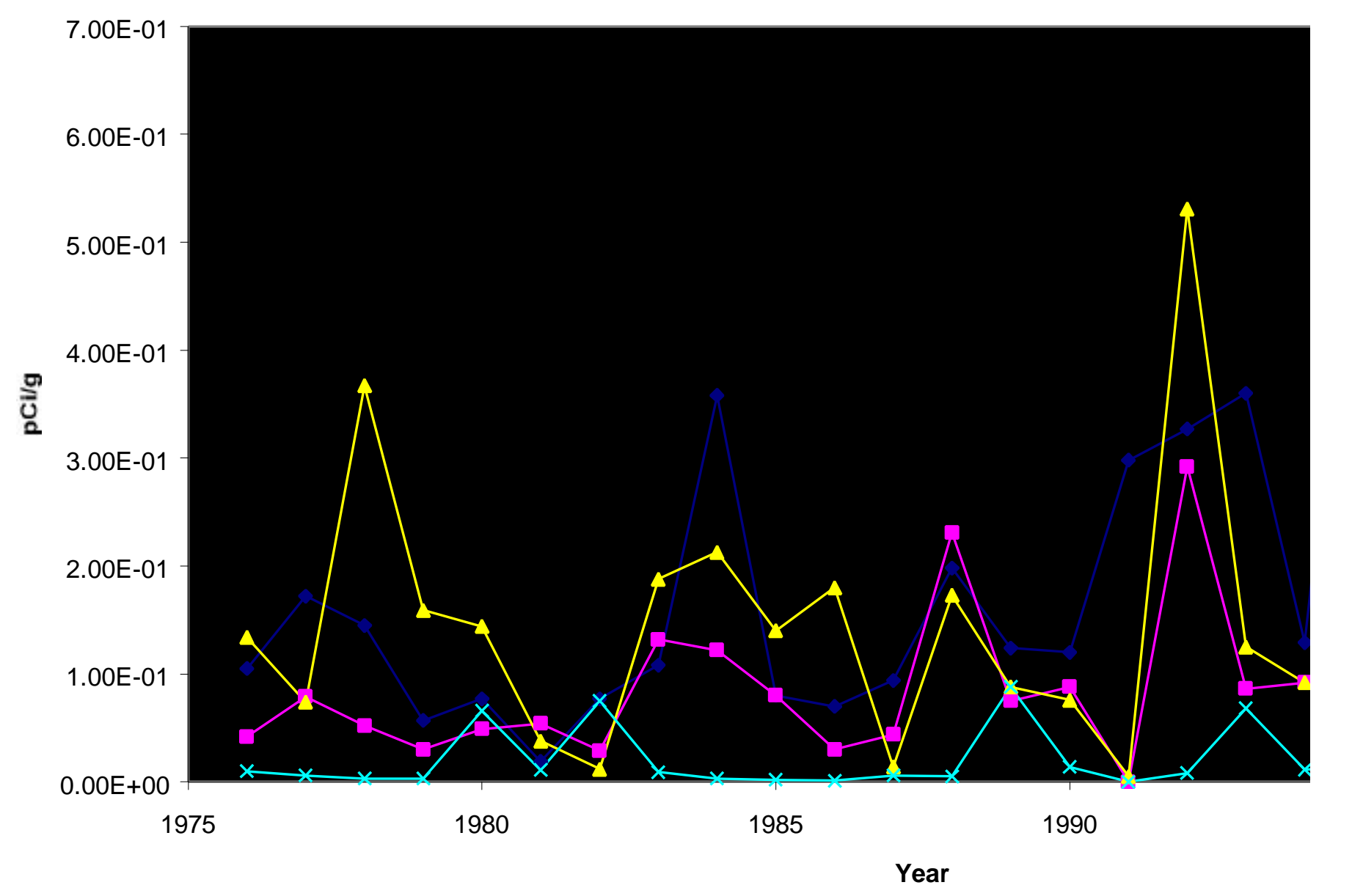

$\rightarrow$ F-Area 2000E $\rightarrow$ F-Area 2000W $\rightarrow$ F-Area $2000 \mathrm{~N} \rightarrow$ F-Area $c$ 
Westinghouse

Savannah River Company

Alken, SC 29808
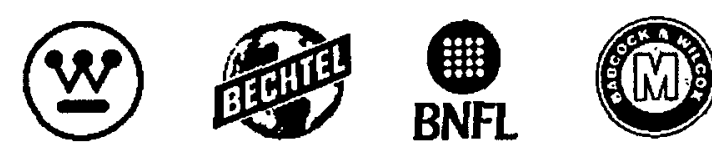

January 24, 2001

ESH-CGP-2001-00014

Ms. Susan B. Alder

Bureau of Drinking Water Protection

Water Use Program

South Carolina Department of Health and

Environmental Control

2600 Bull Street

Columbia, S. C. 29201

Dear Ms. Alder:

2000 WATER USE REPORT: SAVANNAH RIVER SITE

Please find attached the Water Use Report for 2000. This form is provided in accordance with state regulatory requirements specified under the Water Use Reporting and Coordination Act (282 of 1982), Section 49-4-50, as revised.

Also, per our 1/23/01 phone conversation, information on water use at the TNX-Area Air Stripper was not included in reports for 1996 through 1999 . A monthly breakdown for that period is attached for your use.

Please contact Lori Coward at (803) 725-9592 should you have any questions.

Yours very truly,

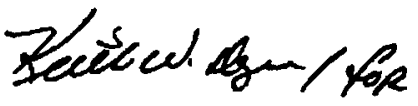

M. B. Hughes, Manager

CERCLA, Geological, and Permitting Section

Environmental Protection Department

Westinghouse Savannah River Company/LLC

Isc/aeo

Att.*

c: D. F. Holroyd, EPA-Region IV*

SRS Administrative Record File (E. R. Palmer, 730-2B)* 
S. B. Alder

ESH-CGP-2001-00014

Page 2

January 24, 2001

bc

C. V. Anderson, 703-A

C. L. Bergren, 730-2B

D. T. Bignell, 742-A

J. E. Bolen, 703-A*

S. M. Butts, 210-S*

L. S. Coward, 742-A*

A. B. Gould, Jr., 703-A

G. S. Hoover, 703-A*

R. F. Keenan, 724-A

B. E. Kuglar, 740-5A*

C. M. Lybrand, 704-22G*

B. Mohip, 679-T*

J. C. Turknett, 730-2B

R. D. Turner, 777-20A*

EPD Fileroom, 742-A*

Records Processing, 773-52A*
File info:

SCDHEC, Water Use Report 10046

DOE 1-8.f

Permanent 
DEPARTMENT OF HEALTH AND ENVIRONMENTAL CONTROL

PERMIT AND DATA ADMINISTRATION SECTION

2600 BULL STREET

COLUMBIA, SC 29201

\section{WATER USE REPORT}

Section I. Water User Identification

Owner Westinghouse Savannah Biver Company

Phone

$725-9592$

Address Building 742-A

City Aiken

Section Il. Monthly Useage

\begin{tabular}{|c|c|c|c|}
\hline Owner's ID & Source lo & $\begin{array}{l}\text { Calc. } \\
\text { Method }\end{array}$ & $\operatorname{Jan} 00$ \\
\hline H-Area & O2IN07G03 & 2 & 31.200 \\
\hline N-Area (Central Shops) & 02IN07G04 & 0 & 0.000 \\
\hline L-Area & 02IN07G05 & 2 & 4.910 \\
\hline K-Area & 02IN07G06 & $\overline{2}$ & 6.250 \\
\hline $\bar{A}$-Area $(300 / 700)$ & 02IN07G07 & 1,2 & 87.322 \\
\hline F-Area & 021N07G08 & 2 & 26.800 \\
\hline B-Area & 02IN07G09 & 1 & 3.334 \\
\hline$\overline{C-A r o a}$ & O2IN07G10 & 0 & 0.000 \\
\hline TNX-Area & 02IN07G11 & 1,2 & 2.704 \\
\hline$\overline{\text { S-Area }}$ & O2IN07G12 & 1 & 0.915 \\
\hline Bldg. 483-7D & $021 N 07 G 13$ & 1 & 0.457 \\
\hline Bidg. $681-3 \mathrm{G}$ & O2IN07S03 & 2 & 223.200 \\
\hline
\end{tabular}

Feb 00

\begin{tabular}{|r|}
\hline \multicolumn{2}{|c|}{ Feb 00 } \\
\hline 28.200 \\
\hline 0.000 \\
\hline 4.750 \\
\hline 6.480 \\
\hline 85.042 \\
\hline 24.100 \\
\hline 6.988 \\
\hline 0.000 \\
\hline 2.666 \\
\hline 1.001 \\
\hline 0.359 \\
\hline 208.800 \\
\hline
\end{tabular}

Mar 00

31.20

0.00

$\frac{4.59}{6.04}$

89.52

$26 . \overline{8 C}$

1.97

$0 . \overline{0}$

2.57

$1 . \overline{20}$

2.16

208.80

\section{TOTAL $\quad \overline{387.092}$}

368.386

$\overline{374.88}$

Section lil. The above is true and correct to the best of my kngyledge. 
DEPARTMENT OF HEALTH AND ENVIRONMENTAL CONTROL

PERMIT AND DATA ADMINISTRATION SECTION

2600 BULL STREET

COLUMBIA, SC 29201

\section{WATER USE REPORT}

Section I. Water User Identification

Owner Westinahouse Savannah River Company

Phone

725-9592

Address Building 742-A

City

Aiken

State

SC

Zip Code

29802

Section II. Monthly Useage

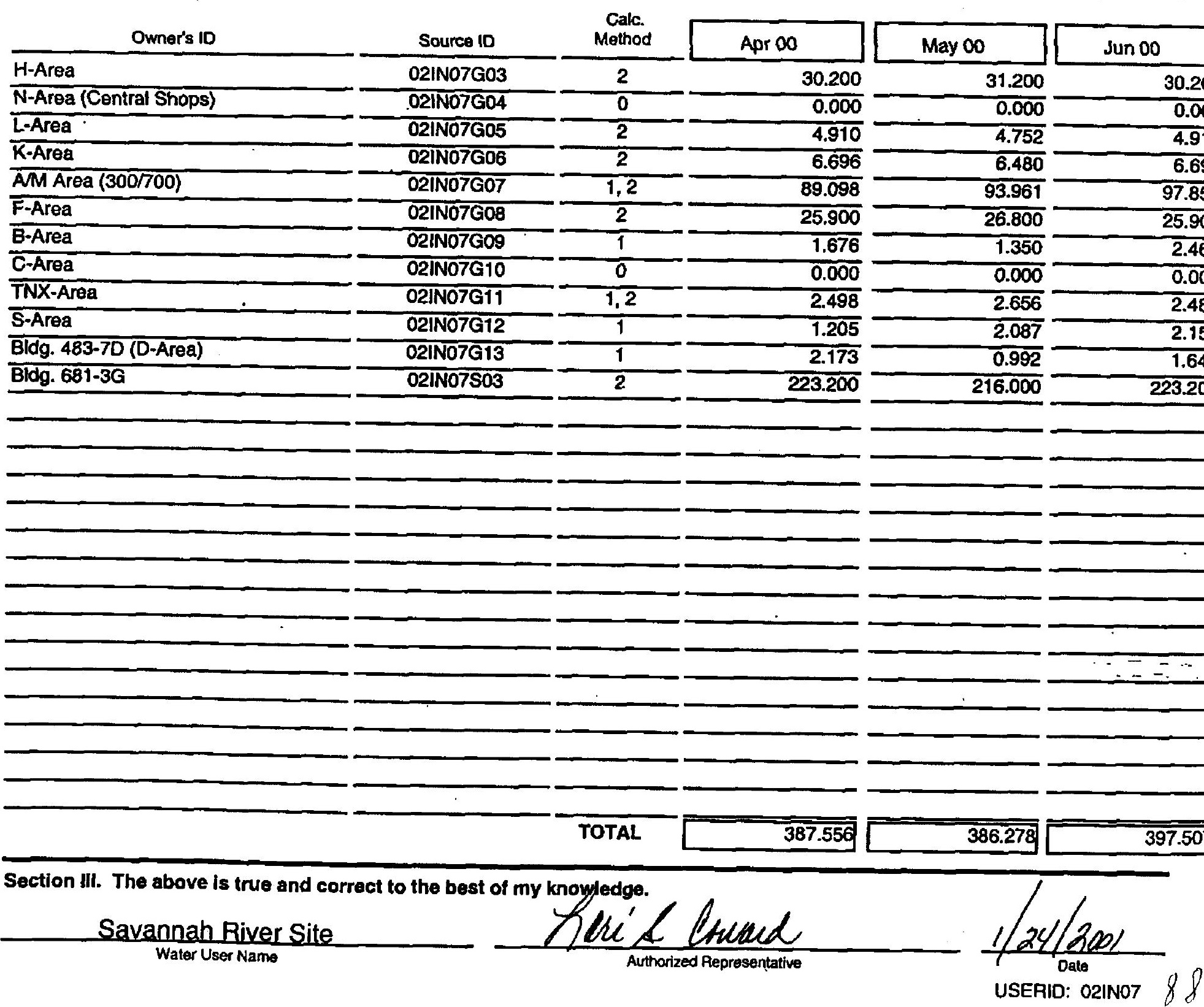

